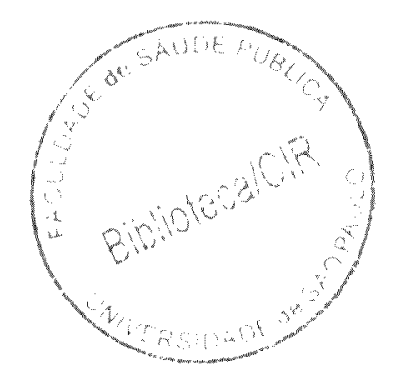

PEDRO LUIZ SILVA PINTO

\title{
CIRCULAÇÃO E CARACTERIZAÇÃO DE Trypanosoma cruzi ISOLADOS DE MAMÍFEROS SILVESTRES CAPTURADOS NO ESTADO DE SÃO PAULO - BRASIL.
}

Tese apresentada à Faculdade de Saúde Pública da Universidade de São Paulo, Departamento de Epidemiologia, para obtenção do título de Doutor em Saúde Pública.

ORIENTADOR: Prof. Dr. José Maria Soares Barata

São Paulo

2000 
Autorizo, exclusivamente para fins acadêmicos e científicos, a reprodução total ou parcial desta tese, por processos fotocopiadores.

Assinatura:

Data:

$40705 / 2001$ (doc) 
Dedico este trabalho:

à minha esposa Neuza

aos meus filhos Rafael $€$ : Daniel

à minha mãe Marlene

ao meu irmão Paulo

à memória de meu pai Alfredo 


\section{AGRADECIMENTOS}

trabalho.

Ao Dr. José Maria Soares Barata pela orientação e confiança əm meu

A Dra. Gentilda Kazuko Funayama Takeda, do Departamento de Ciências Biomédicas da USP, pelo incentivo e colaboração na caracterização biológica dos tripanossomos.

A Dra. Marta Maria Geraldes Teixeira, do Laboratório de Ta:conomia de Tripanossomatídeos do Departamento de Parasitologia ICB-USP, por ter colocado à disposição, reagentes, equipamentos e funcionários para a realização da identificação e caracterização molecular dos tripanosscimos.

A Marta Campaner, Carmem Silva Takata e Flávia Naia, do Laboratório de Taxonomia de Tripanossomatídeos do Departamento de Parasitologia ICB-USP, pela colaboração técnica na caracterização molecular.

A Dra. Teresinha Tizu Sato e Sueko Higa de Lima, do Laboratório de Acarologia do Departamento de Parasitologia ICB-USP, por terem disponibilizado o biotério de manutenção de roedores.

Ao Paulo Auricchio e aos membros da Seção de Mastozoclogia do Museu de Zoologia USP pela colaboração na identificação de roedores

A Dra. Júlia M. M. Souza Felipe e Dra. Márcia de Souza C. Melhem, da Diretoria de Divisåo de Biologia Médica e do Serviço de Parasitcılogia do Instituto Adolfo Lutz - IAL, pelo apoio e incentivo constante.

A Elizabeth Visone Nunes, Carmem S. Guilherme, Oswaldo C. Oliveira Jr, Sansão Westephalen, do Laboratório de Criação de Triatomineos da Seção de Parasitoses Sistêmicas do IAL, pela colaboração nos exames de xenodiagnóstico.

A Maria de Fátima L. Araújo, José E. Tolezano, Márcia da Cınceição Bisugo e Elaine Aparecida Cunha, da Seção de Parasitoses Sistêınicas do IAL, pela colaboração no isolamento e manutenção dos tripanossumos em laboratório.

A Helena H. Higuchi, Rui Larosa e Carlos R. Elias, da Equipe de Campo da Seção de Parasitoses Sistêmicas do IAL, pela colaboração nas capturas dos animais silvestres.

Ao Luiz Eloy Pereira e Renato Pereira de Souza, da Equipe de Campo da Seção de Vírus Transmitidos por Artropodos do IAL. pela orientação na nomenclatura em uso de alguns roedores e nas capturas de animais silvestres da região de lguape. 
Ao João Luis M. Gil, João Mauricio N. S. Filho e Bento Gregóric de Jesus, do Laboratório de Triatomíneos do Departamento de Epideniologia da Faculdade de Saúde Pública - USP - SESA Araraquara, pelo fornecimentos de ninfas de triatomíneos e na colaboração nos trabalhos de captura de animais silvestres na região de Araraquara.

Ao Dr. João Aristeu da Rosa, do Departamento de Ciências Biológicas da Faculdade de Ciências Farmacêuticas UNESP - Araraquara, pelo incentivo e apoio técnico nas coletas de sangue de animais silvestres capturados na região de Araraquara.

Ao Sidnei Stuchi, da Fundação Padre Albino - Catandura, pela revisão do texto. 


\section{RESUMO}

Pinto PLS. Circulação e caracterização de Trypanosoma cruzi issolados de mamiferos silvestres capturados no Estado de São Paulo - Brasil. São Paulo; 2000. [ Tese de Doutorado - Faculdade de Saúde Pública da USP].

A circulação de Trypanosoma cruzi foi estudada em animais silvestres, capturados em duas regiőes do Estado de São Paulo com características ecológicas e epidemiológicas distintas, tendo como parâmetro áreas com ou sem domiciliação de triatomineos. As áreas estudadas compreenderam a região do Planalto Ocidental Jaulista, município de Araraquara, antiga área endémica e regiões do Vale do Ribeira e Litoral Norte, municípios de Eldorado, Iguape e Ilhabela, cons deradas áreas indenes.

Dos 198 animais capturados, foram isoladas 16 amostras de tripanossornos de 11 hospedeiros mamíferos, sendo 1 Didelphis albiventris, 5 D. marsupialis, 2 Proechimys iheringi e 3 Philander opossum.

Das 16 amostras, 9 foram isoladas de xenocultura, 4 de hemocultura e 3 de cultura do aspirado de fígado e baço. Em um marsupial (D. marsupialis) foram isolados flagelados pelos três métodos, em outros marsupiais (1D. albiventris e $2 \boldsymbol{P}$. opossum) os parasitas foram isolados por duas e em sete animais (5 marsupiais e 2 roedores) por um único procedimentı.

Os critérios morfobiológicos permitiram classificar os 16 isolados como $T$. cruzi. Todas as amostras mostraram-se de baixa virulêrıcia para 
ratos e camundongos. Foi possivel através da utilização dessas 3 técnicas, selecionar diferentes populações de $T$. cruzi de um mesmo hospedeiro.

A amplificação do minicírculo de kDNA dos isolados, pela técnica de PCR, com os "primers" P35/36 confirmaram o diagnóstico de $T$. cruzi. A caracterização molecular dos isolados foi baseada na amplificação, pela técnica de PCR, de um segmento da região intergênica do gene de miniexon, que define dois grupos genéticos maiores, $T$. cruzi l e $T$. cruzi ll. Das 9 amostras isoladas de Didelphis, 7 foram classificadas como do tipo $T$. cruzi I e 2 como do tipo T. cruzi II. Estes achados confirmam a circulação preferencial da linhagem T. cruzi I em marsupiais do gênero Didelphis. Ds isolados de Proechimys e Philanders, todos procedentes do município de lihabela, não puderam ser definidos pelo marcador molecular do gene de mini-exon.

A variabilidade dos isolados foi estudada pela técnica de RAPD. Os padrões dos isolados $T$. cruzi I foram distintos dos observados nos is.solacios T. cruzi II. Maiores similaridades foram observadas em isolaclos pertencentes à mesma espécie de animal reservatório e originário da mesma área geográfica. Estes dados sugerem uma maior homogeneidade das populações de $T$. cruzi, circulando em uma mesma área geográfica.

Descritores: Mamiferos silvestres. Trypanosoma cruzi. Caracterização biológica e molecular 


\section{SUMMARY}

Pinto PLS. Transmission and characterization of Trypanosoma cruzi isolates from sylvatic mammals captured in the state of São PauloBrazil. São Paulo (BR); 2000. [ Tese de Doutorado - Faculdade de Saúde Pública da USP].

The circulation of Trypanosoma cruzi among sylvatic animals was studied in two regions of São Paulo State. These regions have distinct ecological and epidemiological features based on human transmission in areas with and without the domestic presence of triatomines. The studied areas were: Planalto Ocidental Paulista region, county of Araraquara, an old endemic area and Vale do Ribeira and Litoral regions, counties of Eldorado, Iguape and Ilhabela, considered non-endemic areas.

Of the 198 animals examined at total, 16 isolates of trypanosomes were obtained from 11 mammals: 1 Didelphis albiventris, 5 D. marsupialis, 2 Proechimys iheringe and 3 Philander opossum.

Nine samples out of 16 isolated by xenoculture, 4 by hemoculture and 3 by culture of liver and spleen puncture. Using these 3 methodologies; it was possible to select different populations of $\mathrm{T}$. cruzi from the same host Using morpho-biological criteria all 16 isolates were classified as $T$. cruzi. All of had low virulence to rats and mice.

The amplification of kDNA minicircle, by PCR, using P35/36 primers, also confirmed the identification of the isolates as $T$. cruzi.

The molecular characterization of isolates was based on the amplfication, by PCR, of a mini-exon gene intergenic region segment, that defines two 
major genetic groups: T. cruzi I and T. cruzi II. Out of 9 Didelphis isolates strains, 7 were classified as $T$. cruzi I and two as $T$. cruzi II. These findings confirm a preferential transmission of the group $T$. cruzi I in marsupials of the genus Didelphis. However, the isolates from Proechimys and Philander all of them coming from lihabela county, did not react with either of the molecular markers.

The variability of the isolates was studied by RAPD. By this method, the patterns of the isolates classified as $T$. cruzi I were distinct from those $T$. cruzi II. Great similarity was observed among isolates from the same host species and belonging to the same geographic area. These findings suggest the existence of $T$. cruzi populations more homogeneous features, circulating in same geographic area.

Descriptors: Sylvatic mammals. Trypanosoma cruzi. Biological and molecular characterizations 


\section{Abreviaturas}

$\mathrm{BHI}$

${ }^{\circ} \mathrm{C}$

DNA

DNA Polimerase

dNTP

EDTA

kDNA

LIT

M

mg

$\mathrm{ml}$

$\mathrm{mm}$

$\mathrm{mm}^{3}$

$\mathrm{mM}$

ng

$\mathrm{nm}$

$\mathrm{pb}$

$\mathrm{pH}$

PBS

PCR

RAPD

RNAse

rRNA
Brain Heart Infusion

grau Celsius

Ácido desoxirribonucléico

Enzima sintetizadora de uma nova fita de [NA

Desoxirribonucleosídeos trifosfatos

Ácido etileno diamino tetracético

Ácido desoxirribonucléico de cinetoplasto

Liver Infusion Triptose

Molar

miligramas

mililitros

milimetros

milímetros cúbicos

milimolar

nanogramas

nanômetro

pares de base

potencial hidrogeniônico

Phosphate Buffered Solution

Polimerase Chain Reaction

Random Amplification of Polymorphic DNA

Ribonuclease

Ácido ribonucleico ribossômico 


$\begin{array}{ll}\text { Sarkosil } & \text { Lauril Sarcosinato de Sódio } \\ \text { SE } & \text { Tampão Tris Salino-EDTA } \\ \text { Taq } & \text { Enzima isolada de Thermus aquaticus } \\ \text { TE } & \text { Tampão Tris Clorídrico-EDTA } \\ \text { Tris } & \text { Hidroximetilaminometano } \\ \text { Tris- } \mathrm{HCl} & \text { Tampão Tris Cloridrico } \\ \mathrm{U} & \text { Unidade de enzima } \\ \mu \mathrm{m} & \text { micrometro } \\ \mu \mathrm{g} & \text { micrograma } \\ \mu \mathrm{l} & \text { microlitros } \\ \mu \mathrm{M} & \text { micromolar }\end{array}$




\section{ÍNDICE}

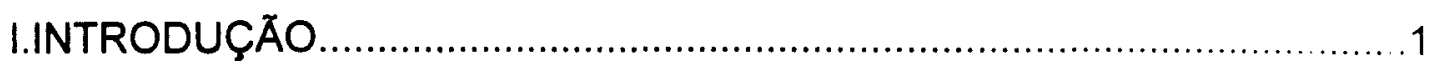

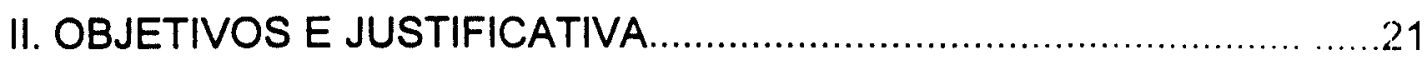

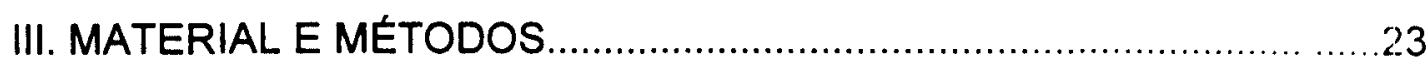

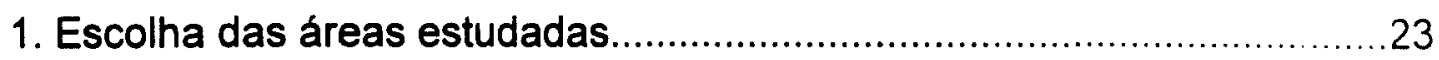

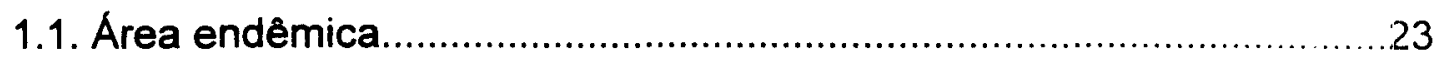

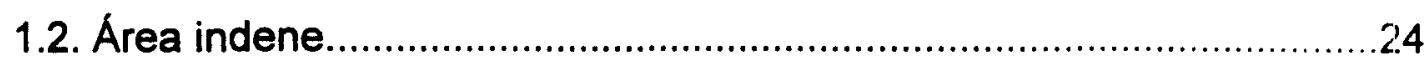

2. Manutenção de colônia de triatomíneos em galinheiro experimental ....... 26

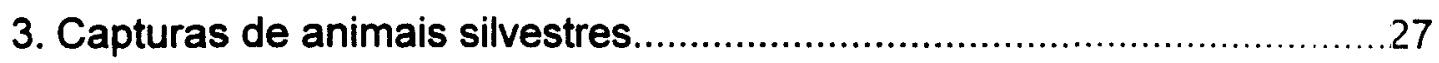

3.1. Procedimentos especificos para a pesquisa de tripanossomos............29

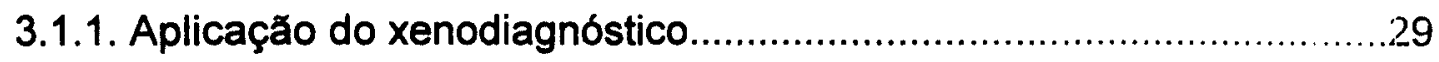

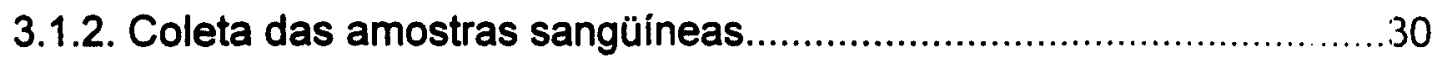

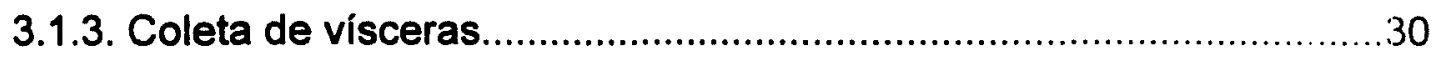

4. Isolamento de $T$. cruzi em animais silvestres..........................................

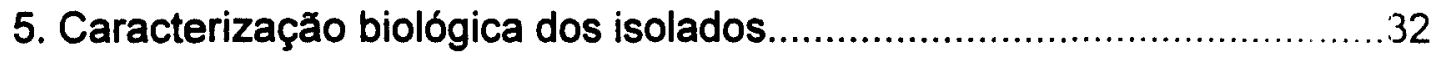

5.1. Comportamento da infecção em animais experimentais.......................32

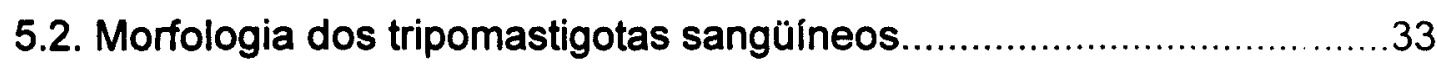

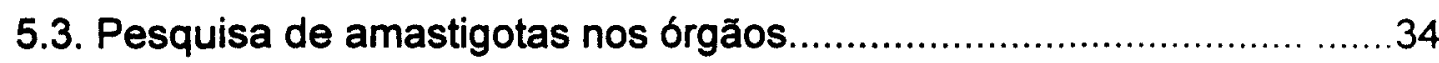

5.4. Desenvolvimento dos flagelados em meio de cultura.............................34

5.5. Desenvolvimento dos flagelados nos vetores........................................ 34

6. Identificação e caracterização molecular.................................................. 35

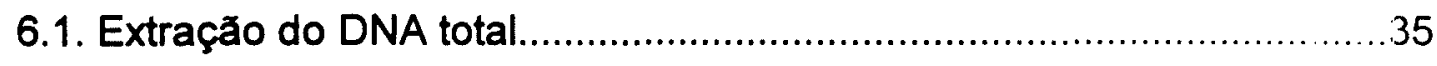

6.2. "Polimerase Chain Reaction" - PCR ................................................36

6.2.1. Identificação molecular pelo minicirculo de kDNA ...............................36 
6.2.2. Caracterização molecular

6.3. "Randon Amplification of Polymorphic DNA" - RAPD ...........................37

6.4. Construção de dendogramas baseados em fragmentos de DNA amplificados por RAPD.

IV. RESULTADOS

1. Avaliação do potencial de domiciliação de triatomíneos...........................40

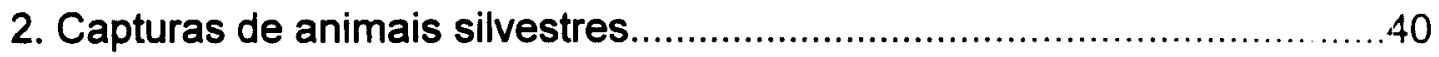

3. Pesquisa de flagelados nos animais silvestres.....................................41

3.1. Isolamento de $T$. cruzi em animais silvestres..................................45

4. Caracterização biológica dos isolados..................................................46

4.1. Comportamento da infecção em animais experimentais.......................46

4.2. Morfologia dos tripomastigotas sangüineos.......................................49

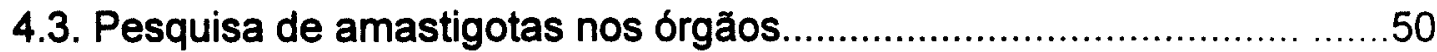

4.4. Desenvolvimento dos flagelados em meio de cultura...........................52

4.5. Desenvolvimento dos flagelados nos vetores....................................54

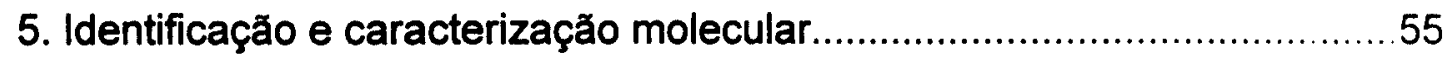

5.1. Identificação molecular pelo minicírculo de kDNA ..................................55

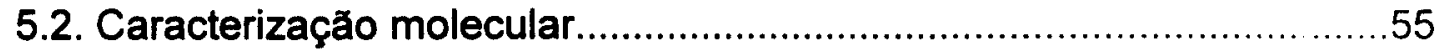

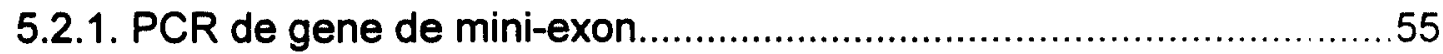

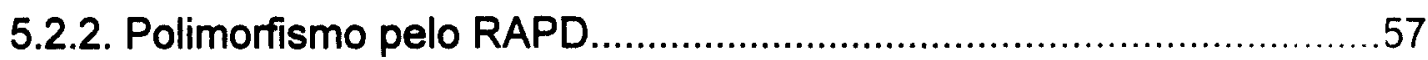

5.2.3. Análise do relacionamento genético através dos dendogramas.......57

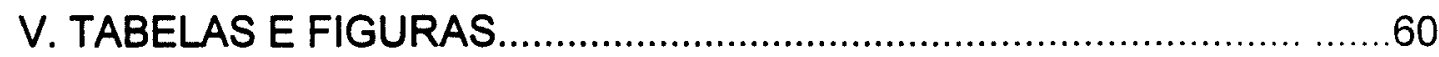

VI. DISCUSSÃO

1. Situação epidemiológica da doença de Chagas......................................8

2. Avaliação do potencial de domiciliação de triatomíneos........................90 


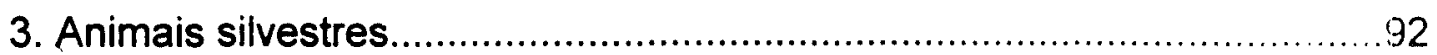

4. Pesquisa de flagelados em animais silvestres.................................95

5. Infecção natural por $\boldsymbol{T}$. cruzi em animais silvestres.........................98

6. Isolamento de T. cruzi em animais silvestres................................103

7. Caracterização biológica dos isolados........................................ 104

8. Identificação molecular pelo minicírculo de kDNA ............................115

9. Caracterização molecular pelo gene de mini-exon............................116

10. Polimorfismo genético entre tripanossomos isolados de animais silvestres........................................................................................... 121

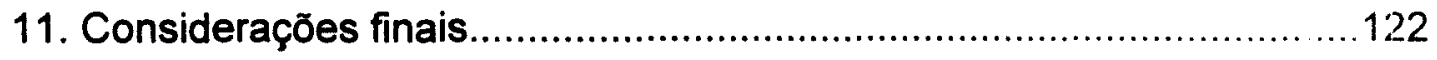

VII. CONCLUSÖES.................................................................. 124

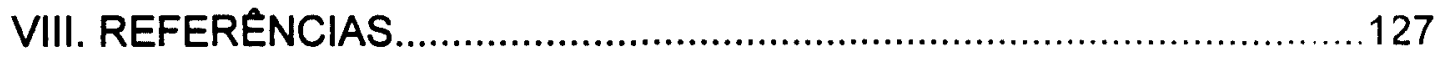

ANEXOS

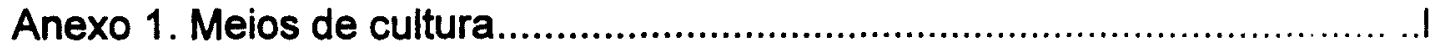

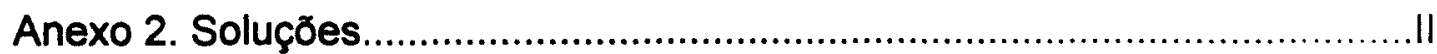




\section{INTRODUÇÃO}

O desenvolvimento tecnológico alcançado no final do sécu.lo $X X$, inegavelmente, contribuiu para a melhoria da qualidade de vida de uma grande parcela da população mundial. Na área da Saúde, esse benneficio pode ser avaliado pelo grau de desenvolvimento obtido no âmbito inédicoassistêncial e profilático de alguns agravos. De fato, a atual tecnologia contribuiu para a melhoria do diagnóstico clínico-laboratorial, colocando à disposição técnicas mais sensíveis e específicas. Com relacão ao tratamento de algumas doenças, houve um progresso na qualidade terapéutica, no sentido de disponibilizar novas drogas com amplo espectro de ação, baixa toxicidade e com menores efeitos indesejáveis. Há que se destacar os avanços da biotecnologia na busca de meios alternativos no controle de doenças, como o desenvolvimento de vacinas com puder de proteção para as populaçð̄es expostas.

Apesar de todos os avanços que a biotecnologia tem proporcionado, algumas doenças ainda figuram como questões relevantes para a Saude Pública. E neste contexto que se insere a doença de Chạjas ou tripanossomiase americana, parasitose determinada pelo Tryparıosoma cruzi, protozoário que circula entre mamiferos e triatomíneos silvestres, em muitos focos naturais dispersos pelas Américas. Essa parasitose se apresenta sob forma endémica em localidades onde ocorreu um processo adaptativo dos vetores, sobretudo, em moradias de áreas rurais e, com menor intensidade, em algumas de áreas urbanas (ACHA e SZYFRES, 1977). O processo vetorial é tido como principal mecanismo de vei: ' ação 
do flagelado e sua importåncia na transmissão da doença de Chagas está relacionada com a domiciliação dos triatomíneos. São apontados outros mecanismos de transmissão, ditos alternativos, destacando-se o transfusional, que passou a ganhar importância com o desenvolvimento urbano e conseqüente migração de indivíduos infectados da área rural para os grandes centros (DIAS, 1985; SCHMUNIS, 1991).

Este complexo relacionamento, envolvendo $T$. cruzi, o horrem, o vetor e os animais reservatórios, faz da tripanossomíase americana una das infecções parasitárias mais estudadas. E considerada enferriidade parasitária de maior impacto social na América Latina, apresentando e evada morbidade associada a diversas formas clínicas, expressivas taxas de mortalidade e de difícil controle (SILVEIRA e REZENDE, 1994; [IAS e SILVEIRA, 1996). Sua importåncia pode ser avaliada pela ampla literatura internacional e nacional produzida nas diferentes áreas do conhecimento, a partir da descrição do primeiro caso clínico, feita por Carlos Chagas, em 1909.

A patogênese da doença de Chagas e a variabilidade de 'ormas clínicas não estão totalmente esclarecidas. Fatores ligados ao hospredeiro humano como: constituição genética, idade, resposta imunitária, estado nutricional, entre outros, poderiam estar associados direta ou indiretamente no processo (TAFURI, 1992). Por outro lado, fatores dependenies do parasita também poderiam estar correlacionados com os achados clínıcos. A presença do parasita e seus antígenos associados às lesōes cardiacas da doença de Chagas na fase crônica vêm reforçar essa hipótese (HIGL $\mathrm{CHI}$ et 
alii, 1993). Tal fato é reforçado, ainda, pela existência de cepas de 7. cruzi. isolados de casos humanos, que apresentam comportamentos biclógicos distintos em animais de experimentação, algumas vezes com alta virulência e elevado grau de patogenicidade (BRENER, 1985).

A infecção humana é constituída por uma fase aguda, pode ido ser assintomática, sintomática ou, em alguns casos, letal e uma fase crônica assintomática que, com o tempo, pode determinar o aparecimento de manifestações clínicas relacionadas com o comprometimento cardiaco, digestivo ou nervoso (PRATA, 1990). Formas com reativação da infecção e comprometimento de vários órgãos têm sido observadas em pecientes crônicos, quando submetidos à terapêutica imunossupressora ou assı́ciados a outras condições que levam à alteração da imunidade, como na infecção pelo HIV (KIRCHHOFF, 1993; SARTORI et alii, 1998).

As dificuldades encontradas no controle e prevenção da parasitcıse estão relacionadas às características dos vetores, dos reservatóricis e do hospedeiro humano. Com relação aos triatomíneos, a grande diversiclade de espécies e a capacidade de adaptação de algumas delas, em diferentes ambientes que não a domiciliar, representam limitações para o controle, uma vez que as medidas estão voltadas ao combate dos vetores domiciliados e, de maneira particular, para Triatoma infestans (SCHOFIELD e DIAS 1991). Essas medidas têm sido efetivas, conseguindo-se ccnter a transmissão em algumas áreas da América Latina, incluindo o Brasil. No entanto, observa-se, nos últimos anos, em áreas submetidas à açăo de inseticidas, colonização no ambiente doméstico e peridoméstico de especies 
ubiquistas como $T$. sordida e Panstrongylus megistus e de espécies antes tidas como exclusivamente silvestres, a exemplo de Rhodnius neglectus. $R$. nasutus, $T$. vitticeps e $T$. rubrovaria. A presença destas espécies de importância secundária, sobretudo no peridomicilio, tem levado à elaboração de novas estratégias para vigilância e controle, diferentes das utilizadas para espécies domiciliadas (SILVEIRA e REZENDE, 1994; DIAS, 1994; WANDERLEY, 1994).

Além disso, a existência de ampla variedade de manniferos domésticos, sinantrópicos e silvestres, suscetiveis ao protozoário, fazem. destes animais, fontes permanentes de infecção e responsáveis pela circulação do T. cruzi nos diferentes ambientes (ROCHA e SILVA et alii, 1975; BARRETTO e RIBEIRO, 1979; WISNIVESKY-COLII et alii, 1985).

A baixa eficácia das drogas para o tratamento etiológico na fase crónica e a inexisténcia de vacinas com potencial de imunização fara as populações suscetiveis, também são fatores que dificultam o controle e a prevenção da doença (SILVEIRA e REZENDE, 1994). Outras fornas de transmissão como a transfusional, por transplantes de órgãos, aleitamerito materno, via congênita e contaminação acidental em laboratório são responsáveis pela transmissão da parasitose em áreas metropolitanas, requerendo aplicação de outras medidas de controle e prevenção (SHIKANAI et alii, 1990; DIAS, 1999). Vale ressaltar, ainda, que em áreas urbanas surgem outros fatores que podem agravar a evolução da doença de Chagas como o "stress" e a co-infecção pelo HIV (DIAS,1999). 
É evidente que a magnitude do problema foi maior no passado, mesmo assim, estima-se que a doença ocorra em 17 paises da fimérica Latina, com um contigente de 16 a 18 milhões de infectados e uma população exposta de aproximadamente 100 milhões de individuos (SCHOFIELD e DIAS, 1999). No Brasil, estes números também são expressivos. A infeç̧ão espalha-se por uma área de 3,5 milhöes de quilômetros quadrados, abrangendo os Estados das regiões Ncrdeste, Centro-oeste, Sudeste e Sul do país (DIAS, 1987). Segundo dados da OMS,1991 estima-se em cerca de 5 milhões de individuos infectados no Brasil.

Considerando as dimensões territoriais, as diversidades reg̣ionais, sob o ponto de vista das áreas geográficas, as características económicas, sociais e culturais das populaç⿸̃es expostas e dos recursos destinaclos aos programas de controle, a doença de Chagas assume importância variada nos diferentes Estados da federação. Tal fato pode ser evidenciacio pela análise dos resultados do Primeiro Inquérito Sorológico Nacional e de outros inquéritos regionais mais recentes, onde as taxas de prevalência variam, consideravelmente, nas distintas unidades federadas, indicando a existência de significativas diferenças inter e intra-regionais (CAMARGO et alii, 1984; OLIVEIRA Jr., 1996; BORGES-PEREIRA et alii, 1996). Em recente estudo, envolvendo duas localidades do Nordeste, foram apontadas diferenças expressivas nas taxas de soro-prevalência de várias infecções, incluindo a de doença de Chagas, mostrando que fatores ecológicos específicos das regiōes estudadas e a estabilidade populacional, sem a ocorrêricia de 
significativa migração, podem condicionar tais variações (CERQUEIRA et alii, 1998).

Na região Norte, nos Estados que compõem a Amazônia brasileira, a doença de Chagas é tida como região indene, com ocorrência, até o momento, de 174 casos autóctones (VALENTE et alii, 1999). Os prirneiros casos autoctones da região Amazónica foram descritos, no Estado do Pará, no final da década de 60 (SHAW et alii, 1969). Mais da metade dos casos registrados na Amazônia estão associados a microepidemias familiares, sem a presença de triatomíneos domiciliados, onde a transmissão fior via oral parece ser a mais provável (VALENTE e VALENTE, 1996; VALENTE et alii, 1999).

Apesar das características peculiares que envolve a transmissão da doença de Chagas na Amazônia, alguns autores chamam a atenção para o risco de endemização da doença na região, devido à presença do ciclo enzoótico natural do T. cruzi e, da forma de ocupação do territóric, com intenso desmatamento, podendo acelerar, desta forma, o processo de domiciliação dos triatomíneos na região e a migração desordenada favorecer o deslocamento de individuos infectados originários das áreas endêmicas (FORATTINI, 1980a; BARATA et alii, 1988; VALENTE e VALENTE, 1996).

De maneira análoga à região Amazônica, consideram-se inderies as áreas correspondentes ao Sistema da Serra do Mar e litoral, formadas pela Floresta Perenifolia Higrófila Costeira e vegetação litorânea, respectivamente, que se estendem do sul do Estado de Santa Catarina até 
o norte do Estado do Rio de Janeiro, abrangendo assim, as regiōes; Sul e Sudeste, respectivamente (FORATTINI, 1980a).

No Estado de São Paulo, o sistema de relevo acidentado e vegetaçăo primária ainda preservada, é integrado por alguns municípios da Grande Săo Paulo e Vale do Ribeira, que, juntos com o litoral, formam parte da área indene do Estado (SILVA, 1980). Em algumas dessas áreas, já foram constatadas invasōes de triatomíneos adultos nos domicílios e os poucos casos autóctones assinalados relacionam-se com atividades exercidas no ambiente silvestre, a exemplo dos casos descritos no Vale do Rikieira e litoral sul (FORATTINI et alii, 1980b; FORATTINI et alii, 1981; CIARAVOLO et alii, 1997).

Segundo FORATTINI (1980), é considerada, ainda como regiảio nāo endêmica, a faixa territorial que percorre paralelamente o Sistema dá Serra do Mar, formada a partir do Nordeste do Rio Grande do Sul, passanco pelo Norte do Estado de São Paulo, na porção correspondente ao Vale do Paraíba, até o Sudeste do Estado da Bahia. Segundo o autor, trata-se de região de colonização antiga com domiciliação triatomínica esporádica, sendo que as razões para ausência ou baixa ocorrência da infecçäo humana não estão plenamente esclarecidas.

De forma particular no Estado de Săo Paulo e, sobretudo, na regiäo do Planalto Ocidental Paulista, estudos entomológicos e sorológicos revelaram, no passado, altos índices de infestação domiciliar por $T$. infestans e taxa de infecção humana em torno de 10\% (CORREA et alii, 1952; COUTINHO, 1962). Com o estabelecimento de um amplo programa 
de controle químico, desencadeado pela Superintendência de Controle de Endemias (SUCEN), foi alcançada a erradicação da principal espécie domiciliada e interrupção da transmissão vetorial, mantendo-se atualmente as medidas de controle em fase de vigilância epidemiológica em todo Estado (WANDERLEY, 1991; WANDERLEY, 1994). Razões de natureza econômica e social também contribuíram para o atual estágio da parasitose em São Paulo. Assim, a expansão da atividade agro-industrial, ocupando extensas áreas e incorporando novas tecnologias de cultivo, alterou toda a estrutura agrária Paulista. As transformaçð̃es ambientais produzidias pelo intenso desmatamento e a intensificação migratória das populações rurais para as áreas urbanas são reflexos deste processo (SILVA, 1980).

Em âmbito nacional, as medidas de controle vetorial e as alterações ambientais, tiveram impacto favorável no panorama atual da endemia, com a diminuição da densidade e das taxas de infecção natural dos triatomíneos domiciliares, reduzindo o risco da transmissão pelo vetor (SILVEIRA e REZENDE, 1994; DIAS e SILVEIRA, 1996).

Apesar da situação epidemiológica favorável, a erradicação do $T$. cruzi em áreas endêmicas dificilmente ocorrerá, devido à ampla distribuiçăo dos focos naturais da infecçăo que, mesmo limitados a pequenos espaços, são responsáveis pela circulação do flagelado entre triatomírieos e mamiferos silvestres. Entre nós, uma análise pormenorizada da constituição dos focos naturais da tripanossomiase americana em regiões dos Estados de São Paulo e Minas Gerais mostrou grande variabilidade dos ecótopos, onde triatomíneos e mamiferos convivem (BARRETTO, 1967 b). 
Os focos naturais são definidos como unidades ecológicas esitáveis, onde existem biocenoses constituídas por mamiferos silvestres, parasitados por T. cruzi, que servem de fonte alimentar para triatomíneos silvestres e estes podem transmitir o flagelado a outros animais susceptíveis, sem a participação humana (BARRETTO, 1967b). Os focos naturais são estáveis, mas, quando alterados por fatores naturais ou pela interferéncia humana, podem ter os ecótopos destruidos, causándo a eliminação, redução ou deslocamento da biocenose. Outra consequëência considerada de grande importância epidemiológica é a possibilidiade de ocorrer concentração de reservatórios e vetores silvestres em áreas de matas residuais com a potencialização dos focos naturais (BARFETTO, 1967a). Tais fatos podem explicar as diferenças observadas nas taxas de infecção natural por $T$. cruzi em animais silvestres e sinantrópicos de diferentes paises do Continente Americano (KARSTEN et alii, 1992; WISNIVESKY-COLLI et alii, 1992; ZAVALA-VELAZQUEZ et alii, 1996; HERRERA e URDANETA-MORALES, 1997) e de diversas regiões do Brasil (ROCHA e SILVA et alii, 1975; BARRETTO e RIBEIRO, 1979; FERNANDES et alii, 1999).

A infecção natural por T. cruzi tem sido assinalada em uma ampla variedade de animais silvestres, pertencentes às ordens Marsupialia, Rodentia, Edentata, Chiroptera, Carnivora, Lagomorfa, Artiodactyla e Primata. Contribuição importante, neste sentido, foi dada por BARRETTO e RIBEIRO (1979), que organizaram uma relação de reservatórios silvestres encontrados nos países Americanos, baseada em dados da literatura e de 
observaçర̄es resultantes da série de trabalhos denominada "Estudos sobre reservatórios e vetores silvestres do Trypanosoma cruzi ". Muito єmbora, os autores admitissem a impossibilidade de relacionar todas as espécies com potencial de reservatório, devido à falta de critérios seguros na identificação dos flagelados, este compilado é um dos mais completos e abrangentes da área.

Contrapondo-se ao padrão da infecção humana, a evolựão da infecção em animais reservatórios pode produzir parasitemias aparentes e de longa duraçăo, como as observadas em marsupialis do Gênero Didelphis (FERNANDES et alii, 1991). De maneira particular, estes animais apresentam altos indices de infecção pelo $T$. cruzi, sem desenvolver, contudo, processos patogênicos gerais (FERNANDES et alii, 1989).

Infecçס̄es experimentais, em Didelphis marsupialis e Lutreolina crassicaudata, demonstraram que o flagelado pode ser encontrado no interior das glândulas anais, sob as formas epimastigotas e tripomastigotas metacíclicas (DEANE et alii, 1984; STEINDEL et alii, 1988a). Em animais naturalmente infectados, este comportamento tem sido assinalado com menor freqüência e intensidade (STEINDEL et alii, 1988b; FERNANDES et alii, 1989). Esses achados podem ter grande importância epidemiológica, considerando que, em animais infectados, o conteúdo das glândulas anais são eliminadas na porção posterior do reto, onde já fcram observadas formas tripomastigotas metacíclicas (DEANE e JANSEN, 1988). Estes dados sugerem que os marsupiais, em certas circunstâncias, possam servir de 
fonte de infecção e transmitir o protozoário pela contaminação de alimentos (MARCONDES et alii, 1988).

Entre os reservatórios silvestres e domésticos, a contaminação por via oral, a partir da ingestão de insetos infectados ou pela predação de animais infectados, representa outra forma de transmissão (PESSOA, 1958: RIBEIRO et alii, 1987; SCHWEIGMANN et alii, 1995).

Entre animais domésticos, o cão e o gato constituem os principais reservatórios (WISNIVESKY-COLLI et alii, 1985). A importância epidemiológica desses reservatórios entre nós foi bem avaliada por MOTT (1978), que demonstrou associaçăo entre soropositividade em crianças e a presença de animais domésticos infectados por $T$. cruzi em seus domicilios.

Em nosso meio, em estudos anteriores envolvendo reservatćrios do T. cruzi, procurava-se estudar características biológicas do parasita com o intuito de verificar e diagnosticar a infecçăo natural nas mais diferentes espécies animais. (DEANE, 1964; BARRETTO, 1965; MELLO, 1982). Pesquisas mais recentes procuram avaliar não só a circulaçãa do protozoário entre os reservatórios, mas a inter-relação dos ciclos de transmissão silvestre e domiciliar, com a preocupação de identificar possiveis re-introduçōes do flagelado em áreas submetidas ao programa de controle (FERNANDES et alii, 1991; DIOTAIUTI et alii, 1995) ou a sua introduçăo no ambiente doméstico, em regiōes tidas como indene (FERNANDES et alii, 1999). A busca de marcadores epidemióógicos, através de características bioquímicas e moleculares dos parasitas, 
constituem ferramentas valiosas para estes propósitos (MILES et alii, 1977; MILES et alii, 1980; ZINGALES et alii, 1998; FERNANDES et alii, 1999).

$O$ isolamento do flagelado tem sido possivel pelo xenodiagnóstico, pelo cultivo de sangue, fragmentos e aspirados de vísceras ou conteúdo intestinal dos vetores, em meios acelulares, e pela inoculação intraperitoneal de sangue dos reservatórios ou de fezes de triatomíneos infectados por $T$. cruzi em animais de experimentação.

Uma das questőes relevantes nos estudos de reservatórios é a identificaçăo precisa dos flagelados encontrados nesses animais, uına vez que outras espécies de tripanossomos podem estar presentes. Já foram assinalados, no Brasil, espécies dos subgêneros Herpetosoma, Megatrypanum e Trypanozoon parasitando animais silvestres e domésticos (BARRETTO e RIBEIRO, 1981; DEANE e JANSEN, 1990; NUNES e OSHIRO, 1990).

No entanto, apenas T. (Herpetosoma) rangeli apresenta importância médica-epidemiológica, pois mesmo considerado não patogênico para o hospedeiro humano, essa espécie pode evoluir nos mesmos vetores e reservatórios que T. cruzi. Em algumas áreas da América Latina e Central, sua ocorrência pode sobrepor à da espécie patogênica. No Brasil, já foram reconhecidos alguns vetores desse flagelado como: Rhodnius pictipes, $R$. robustus e $\boldsymbol{R}$. domesticus, assim como mamíferos naturalmente infectados pertencentes a diferentes ordens (CUBA CUBA, 1998). MILES et alii (1983) foram os primeiros a caracterizar $T$. rangeli isolados de animais silvestres, triatomíneos e flebotomíneos da região Amazônica. Posteriormente, 
STEINDEL et alii (1991) isolaram e identificaram este flagelado em Echimys dasythrix, roedor silvestre, capturado no Estado de Santa Catarináa. Mais recentemente, foram descritos, na região norte do Estado do Amazonas, os primeiros casos humanos da infecção (COURA et alii, 1996).

T. rangeli e T. cruzi apresentam características morfológicas e biológicas distintas; no entanto, algumas vezes, podem ocorrer dúvidas na identificação. Dentre os critérios biológicos, o exame concomitante das fezes, hemolinfa e glândulas salivares de triatomíneos naturalmente infectados ou provenientes de xenodiagnóstico, representa um bom parâmetro para o diagnóstico de T. rangeli (MANSFIELD, 1977). Atualmente, critérios bioquímicos e moleculares são usados na caracterizaçăo e identificação das espécies em amostras isoladas de vetores, casos humanos e animais silvestres (SCHOTTELIUS e MUILLER, 1984; FRASCH et alii, 1981; VALLEJO et alii, 1994; RECINOS et alii, ^994).

Para a identificação de amostras de $T$. cruzi isoladas de reservatórios animais, têm sido empregados critérios morfológicos e biológicos. Assim, a morfologia associada aos índices biométricos; o comportamento da infeç̧ăo em animais de laboratório, com o estudo da parasitemia, do viscerotropismo e da mortalidade; as provas de imunidade cruzada realizadas em animais experimentalmente infectados e reinoculados com amostras virulentas de $T$. cruzi de origem humana; a evoluçăo dos flagelados no intestino posterior de triatomíneos e o desenvolvimento dos parasitas em meios celulares e acelulares, constituem parâmetros que, ao serem analisados em conjunto, podem levar a um diagnóstico mais seguro (BARRETTO, 1965; BARFiETTO 
et alii, 1980). No entanto, como ressaltaram ROCHA e SILVA et alii (1975), o emprego integral destes parâmetros apresentam restrições de ordem operacional e de custo, principalmente quando envolvem a identificação de vários isolados. Desta forma, o desenvolvimento dos parasitas em animais suscetiveis como os camundongos e ratos jovens, com a constatação de estágios intracelulares, e o encontro de tripanossomos no tubo intestinal de triatomíneos provenientes de xenodiagnóstico poderiam representar critérios minimos para a identificação.

Recentemente tém sido utilizados procedimentos moleculares com o propósito de identificar e classificar diferentes tripanossomos. Dentro deste amplo grupo de protozoários, uma das estruturas mais estudadas tem sido o cinetoplasto, representado por uma região rica em DNA contido em uma mitocóndria presente em todos os flagelados pertencentes à ordem KInetoplastida, incluindo o $T$. cruzi. O kDNA representa cerca de $25 \%$ de todo DNA do flagelado. Estruturalmente, o kDNA é formado por uma rede de moléculas interligadas de conformação circular de dois tamanhos, designados de maxicírculos e minicírculos (SIMPSON, 1986). As molèculas de minicírculos de kDNA, entre as espécies de tripanossomos, são heterogêneas em relação à seqüência de nucleotideos, fazendo corn que seja possível a distinção entre as espécies por meio da análise molecular deste componente. Por outro lado, tem sido demonstrada, dentro da mesma espécie, a existência de regiớes heterogêneas, intercaladas a ręgiões altamente homogêneas quanto à seqüência, ao arranjo e à posição dos nucleotídeos nas moléculas (RAY, 1989). Sendo assim, estas caracteristicas 
do kDNA, quando analisadas por diferentes metodologias moleculares. como o tratamento das moléculas com endonucleases de restriçăo, originando diferentes padrões eletroforéticos, denominados Esquizodemas (MOREL et alii, 1980; FRASCH et alii, 1981) ou por amplificação de segmentos específicos pela Reação em Cadeia da Polimerase (PCR) (STURM et alii, 1989), constituem marcadores genotípicos aplicacjos em taxonomia e diagnóstico.

Para T. cruzi, a metodologia que emprega a amplificação de segmentos da molécula de kDNA pela técnica de PCR tem sido usada na detecção de parasitas em amostras sangüíneas de chagásicos crônicos (AVILA et alii, 1993; JUNQUEIRA et alii, 1996) e de annimais experimentalmente infectados (KIRCHHOFF et alii, 1996), em fezes de triatomíneos (SHIKANAI-YASUDA et alii, 1996) e na análise de diferentes isolados de origem humana, de triatomíneos e de animais reservatórios (AVILA et alii, 1990).

Outra questăo importante no estudo dos isolados de $T$. cruzi está relacionada com as variações intra-específicas. Há, na literatura, ampla evidência de que o flagelado não está representado por uma população homogênea, mas por sub-populações que poderiam parasitar hospedeiros humanos e não humanos (MILES, 1979). Essas sub-populações, isoladas de diferentes hospedeiros, apresentam grande heterogeneidade quanto às características biológicas, antigênicas, bioquímicas e genéticas (BFENER, 1985). Em vista dessa variabilidade, tem sido sugerido uma possível relação entre populaçőes de parasitas e predomínio de manifestações clínicas 
observadas em determinadas áreas geográficas (MILES et alii, 1981). No entanto, como já assinalado no início desta introdução. o mecanismo patogênico e a variabilidade de formas clínicas não estão totalmente esclarecidos.

Alguns dos critérios empregados para distinguir T. cruzi de: outras espécies de tripanossomos são também utilizados para a caracterização de isolados de T. cruzi. Assim, os parâmetros biológicos são baseados, sobretudo, no desenvolvimento dos parasitas em animais de experimentaçăo, no comportamento em meios de cultura celular e acelular e na sensibilidade a agentes quimioterápicos, quando se tratam de isolados de origem humana (BRENER, 1985). O comportamento da infecção em animais de laboratório leva em conta a análise morfológica das formas sangüineas, com distinçăo das formas delgadas, intermediárias e larģas; o viscerotropismo e a virulência expressa pelo período pré-patente, curva de parasitemia e indice de mortalidade. Esses parâmetros tên sido amplamente usados na caracterização de isolados e sub-populações do flagelado ( MARQUES de ARAÚJO e CHIARI, 1988; CARNEIRO et alii, 1991; MAGALHÃES e ANDRADE, 1991; OLIVEIRA et alii, 1993).

As características bioquímicas e moleculares também têm revelado uma grande variabilidade entre T. cruzi. MILES et alii (1977; 1978: 1980) definiram três padrơes isoenzimáticos, denominados de Zimodemas, que foram relacionados com os ciclos de transmissão. O padrão Zimodema 2 (Z2) encontrado nos isolados provenientes de chagásicos crônicos e animais domésticos são resultantes do ciclo de transmissão doméstica e os 
Zimodemas 1 e 3 (Z1 e Z3) apresentados pelos isolados de triato nineos animais silvestres e de casos humanos na Amazônia, resultam do ciclo de transmissão silvestre.

Metodologias baseadas em marcadores genéticos têm demonstrado que a população de flagelados está dividida em sub-populaçōes heterogêneas. As análises dos padrōes eletroforéticos, resultarıtes da clivagem do kDNA por endonucleases de restrição, Esquizodemas, tẹmm sido empregadas para diferenciação de isolados (MOREL et alii, 1980) e, até mesmo, de sub-populações (clones) desta espécie que diferem em suas caracteristicas biológicas (BRENER, 1985).

Para estudos de variabilidade genética foi desenvolvida a técnica de "Random Amplification Polymorphic DNA (RAPD)", que consiste na amplificação de fragmentos de DNA pela técnica de PCR, utilizando-se pequenos oligonucleotídeos de seqüências aleatórias como "primers". A variabilidade entre isolados pode ser determinada pela comparação dos perfis de fragmentos amplificados. Com esta abordagem, tem sido possivel constatar o polimorfismo genético entre espécies e sub-espécies de protozoários, incluindo $T$. cruzi (TIBAYRENC et alii, 1993). Várias investigaçర̃es, usando esta metodologia, têm mostrado aspectos distintos da estrutura genómica de $T$. cruzi. Em estudos realizados com isolados originários do Brasil, Bolivia, Chile e Venezuela, os resultados do RAPD confirmaram a existência de uma estrutura populacional clonal, já reivelada por outras metodologias (TIBAYRENC et alii, 1993). A comparaçāo dos perfis de RAPD entre os isolados, pertencentes ao mesmo Zimodema, 
apresenta uma grande concordáncia, mostrando que, cada grupo é constituido por parasitas geneticamente mais relacionados (STEINI)EL et alii, 1993).

Atualmente, os genes ribosso̊micos, (rRNA) e de mini-exon (SI.RNA), têm sido investigados e utilizados como marcadores genéticos para estudos de evolução e ou de variabilidade entre diferentes gêneros e espécies de protozoários da ordem Kinetoplastida (MASLOV et alii, 1996; STLRM et alii, 1995; FERNANDES et alii, 1994). Os genes ribossômicos săo estruturalmente formados por seqüências codificadoras constituidas pelas subunidades LSU (subunidade maior $24 S \alpha$ e $24 S \beta$ ) e SSU (subunidade menor 18S), flanqueadas por seqüéncias espaçadoras que se repetern mais de 100 vezes no genoma desses organismos. As diferenças no arranjo dessas regið̄es têm sido utilizadas nas identificaçðes de tripanosomatídeos. As análises das sequências ribossômicas por enzimas de restrições "riboprinting" têm mostrado uma variabilidade genética no grupo (NOYES et alii, 1997). CLARK e PUNG (1994) ao estudarem o polimorfismo na subunidade SSU do gene IRNA, classificaram os isolados de $T$. cruzi em trés grupos distintos, denominados de Ribodemas I, II e III.

Os genes de mini-exon apresentam unidades transcritas e nảo transcritas, alinhadas e repetidas ao longo do gene. A região transcrita é formada por um exon com 39 nucleotídeos, que é conservado entre os tripanosomatideos, e por um intron de 55 a 101 pares de bases (pb), que mostra alguma variabilidade no grupo. A região não transcrita (espaçadora) apresenta alto grau de variabilidade entre os organismos. Diferenças no 
tamanho da unidade de repetiçăo e na seqüência deste gene, têm sido usadas como parâmetros nos estudos de variabilidade entre as diferentes espécies de flagelados pertencentes à ordem Kinetoplastida (STURM et alii, 1995; FERNANDES et alii, 1994). Estudos comparativos entre as seqüéncias da região não transcrita do gene de mini-exon de $T$. cruzi, isolado de casos humanos, triatomineos e animais silvestres, mostraram uma baixa similaridade entre os isolados (SOUTO et alii, 1996).

A caracterizaçăo de isolados de $T$. cruzi, pela técnica de PCR, de seqüéncias ribossómicas tais como a região promotora rRNA, subunidade $24 S \alpha$ e de seqüências do gene do mini-exon, permitiu dividir os diferentes isolados em dois grandes grupos (NUNES et alii, 1997; SOUTO et alii, 1996). A análise pelo RAPD demonstrou que os dois grupos apresentaram uma correspondéncia entre duas linhagens de alta divergência filogenética, denominadas de Linhagem 1 e 2 (SOUTO et alii, 1996). Foi demonstrada uma associação da Linhagem 1 com o ciclo de transmissão doméstico e da Linhagem 2 com o ciclo de transmissão silvestre (FERNANDES et alii, 1998a; ZINGALES et alii, 1998).

O dimorfismo genético encontrado nos isolados de $T$. cruzi tem ampla relaçăo com os Zimodemas Z1 e Z2 descritos por MILES et alii (1977; 1980) e com os Ribodemas propostos por CLARK e PUNG (1994). Assim, SOUTO et alii, 1996 verificaram uma concordância entre amostras classificadas como Zimodema Z2 e Linhagem 1 e de Zimodema 1 com a Linhagem 2. Da mesma maneira, uma correspondéncia entre Ribodema II / III com a Linhagem 2 e Ribodema I com Linhagem 1, também foram observadas 
(CLARK e PUNG, 1994). Atualmente, na tentativa de unificar as designações entre as duas Linhagens foi proposto o uso de T. cruzi I, quando os isolados forem equivalentes ao Zimodema Z1 (MILES et alii, 1977; 1978), Linhagem 2 (SOUTO et alii, 1996) e Ribodema II / III (CLARK e PUNG, 1994) e T. cruzi II, quando os isolados forem equivalente ao Zimodema Z2, Linhagem 1 e Ribodema I. (MOMEN, 1999).

Em investigação recente, FERNANDES et alii (1999) descreveram, em área não endêmica de domínio da Mata Tropical Atlântica Costeira, a ocorréncia das duas populaçסes infectando animais silvestres. Os autores encontraram, também, uma relaçăo direta entre $T$. cruzi I (nova designação) infectando Didelphis marsupialis e T. cruzi II (nova designação) infectando Primatas, concluindo que as espécies de reservatórios poderiam atuar corno filtros biológicos na seleção de um determinado genótipo do parasita. Estes dados são de grande importáncia epidemiológica mostrando a complexidade do ciclo silvestre, no sentido de uma co-existência das duas populações, circulando em distintos reservatórios, no mesmo ambiente. Fica patente a possibilidade do estabelecimento do ciclo doméstico, em área não endêmica ou em regiôes onde a transmissão domiciliar já foi interrompida, às custas da introdução de reservatórios silvestres infectados com $T$. cruzi ll e a presença de espécies de triatomíneos com hábitos ubiquistas. Diante do exposto, torna-se necessário empreender novos estudos, referentes aos isolados de T. cruzl em animais silvestres de outras regiões, que possam trazer subsidios para melhor entendimento destas questర̋es. 


\section{OBJETIVOS E JUSTIFICATIVA}

Este trabalho teve por objetivo geral estudar a circulação do $T$. cruzi e possiveis linhagens, em animais reservatórios capturados em duas regiðes do Estado de São Paulo, que apresentam características ecológicas e epidemiológicas distintas para a transmissão humana. A primeira situada no Planalto Ocidental Atlântico, correspondente à antiga área endêmica do Estado, cuja principal característica era a presença de $T$. infestans domiciliado e que, atualmente, ainda conserva características de domiciliaçăo por espécies secundárias como: $P$. megistus e $T$. sordida, revelada pela técnica de galinheiro experimental. A segunda regiăo, compreendendo o Vale do Ribeira e Litoral Norte, sem a ocorrêrıcia de domiciliação pelas espécies citadas e, portanto, consideradas áreas indenes.

Como objetivos especificos, foram isolados e mantidos em laboratório os tripanossomos, para: a) criação de banco de cepas de diferentes regiões do Estado de Săo Paulo; b) identificação e caracterização biológica desses tripanossomos por meio dos parâmetros morfológicos, desenvolvimento em meio de cultura acelular, evoluçăo em animais de experimentação e em vetores; c) identificaçăo dos isolados por metodologias moleculares, como a técnica de PCR empregada nas análises de KDNA, para; d) caracterizar a(s) linhagen(s) de T. cruzi que circulam nas áreas estudadas, usando, como marcador genético, sequéencias do gene de mini-exon amplificadas pela técnica de PCR; e e) estudar a variabilidade dos isolados de T. cruzi pela técnica de RAPD. 
Com estas abordagens, pretende-se estudar a circulação do $T$. cruzi em animais silvestres, identificando os reservatórios de maior potencialidade nas áreas trabalhadas e possibilitando uma comparação com os dados já existentes em outras regiōes do pais. O conhecimento da variabilidade genética e do comportamento dos isolados de $T$. cruzi nos hospedeiros vertebrados poderá gerar subsídios para classificação de cepas quanto ao grau de virulência e patogenicidade. O conjunto das variações intraespecificas dos isolados obtidos com as análises morfológicas, biológicas e moleculares poderão ser usados como marcadores epidemiológicos

Pretende-se também estabelecer metodologias mais adequadas na caracterização fenotípica e genotípica de $T$. cruzi isolados de animais silvestres, que possam servir de apoio a programas de vigilåncia em laboratórios de Saúde Pública.

Finalmente, espera-se obter um instrumento que possa avaliar o potencial de risco, quando da introdução ou deslocamento de populações humanas e de animais reservatórios em áreas silvestres, onde haja condições ecológicas propicias para a manutenção da zoonose. 


\section{MATERIAL E MÉTODOS}

\section{Escolha das áreas estudadas:}

As áreas de estudo foram selecionadas conforme o critério de divisão de "área endêmica" e "área indene" da doença de Chagas, definido por SILVA (1980). Assim, área endêmica refere-se às localidades onde foi registrada a domiciliação do $T$. infestans infectado por $T$. cruzi, e área indene, aquelas localidades onde não foi constatada a domiciliação do triatomíneo. Na Figura 1, está representada a delimitação da área endémica em relação às quatro divisões morfo-estruturais do Estado de São Paulo.

Os trabalhos de captura de animais reservatórios foram realizados no Estado de São Paulo, nos municípios de Araraquara (região do Planalto Ocidental Paulista), Eldorado (região do Vale do Ribeira), Iguape (regiåo do Vale do Ribeira), e llhabela (região do Litoral Norte). As localizações dos 4 municípios Paulistas estão assinaladas na Figura 2.

\section{1. Área endêmica:}

A área endêmica ocupa quase totalmente o Planalto Ocidental Paulista, toda a área que compreende a Depressão Periférica Paulista e parte do Planalto Cristalino Atlântico (Figura 1).

A micro-região homogênea de Araraquara situa-se nos limites oriental do Planalto e está contida nesta área. O município de Araraquara localiza-se no centro da referida micro-região (Figura 2), caracterizando-se por apresentar profundas alterações ambientais em função da intensa 
atividade agricola do tipo extensiva, com o predomínio da cultura da cana de açúcar e da laranja. A região apresentava cobertura vegetal original composta pela Floresta Subcaducifolia Tropical, persistindo atualmente algumas "ilhas florestadas" e áreas de cerrado. Do ponto de vista epidemiológico, há constatação de triatomíneos com hábitos domiciliares, revelados por galinheiro experimental instalado na área. As capturas de animais silvestres foram realizadas na reserva de mata da Fazenda Săo Lourenço e Sítio Carandá, onde, nesse último, já estava instalado o galinheiro experimental.

\section{2. Área indene:}

A área indene é constituída pela porção extremo ocidental do Planalto Paulista e pela parte oriental do Estado, correspondente às micro-regiōes homogêneas do Vale do Ribeira, Baixada Santista e Litoral Norte, que formam, o litoral Paulista (Figura 2).

A região do Vale do Ribeira é composta pela Bacia Hidrográfica do Rio Ribeira de Iguape e inclui 16 municípios. A região é considerada de baixo desenvolvimento sócio-econômico devido, principalmente, à topografia acidentada e às condições climáticas que inviabilizam algumas práticas agrícolas, mas que favorecem as culturas da banana, arroz e chá. Grande parte dos municipios mantém áreas com vegetação natural intacta ou pouco alterada com cobertura do tipo Floresta Tropical Latifoliada. Do ponto de vista epidemiológico, não há registro de domiciliação de $T$. infestans no Vale do Ribeira. No entanto, já foi constatada a invasão de triatomíneos 
adultos em domicilios (WANDERLEY,1994b). A circulação do parasita é reconhecida no meio silvestre e a transmissão humana já ocorreu de maneira casual, na ausência de triatomineos domiciliados (FORATTINI et alii, 1980b; FORATTINI et alii, 1981). O município da Estância Turística de Eldorado, antiga Eldorado Paulista apesar de compor a micro-região homogênea do Vale do Ribeira, não guarda relações com o litoral, devido a sua posição ocidental; já o municipio de Iguape está localizado na porção oriental litorânea do Vale do Ribeira.

O município de llhabela, representa a delimitação entre o litoral norte e sul. Este município é composto por dezenas de ilhas, ithotas e lajes com área total que corresponde a $336 \mathrm{Km}^{2}$. Acima dos 500-600 metros de altitude, encontra-se densa vegetação de Mata Atlântica. A população concentra-se na faixa próxima ao mar, sendo que a atividade económica básica está voltada para o turismo. Apresenta características epidemiológicas parecidas com a região descrita anteriormente, mas com isolamento geográfico.

As capturas de animais reservatórios foram realizadas em áreas florestadas dos municípios de Eldorado, Iguape e de Ilhabela. Em Eldorado, os trabalhos foram realizados em matas da periferia da cidade e em área de sítio no Bairro Cordas, distante $40 \mathrm{Km}$ do centro urbano. Em Iguape as capturas foram feitas nas áreas de matas do "Centro Estadual de Educação Tecnológica Paula Souza" e nas localidades de Porto do Ribeira e Pedra Grande (Estrada do Icapara). Na Ilhabela, o estudo foi realizado nas localidades de Água Branca, Feiticeira, Reino, Cocaia e Buraco Fundo. 
Essas capturas também estavam vinculadas ao projeto "Ecoepidemiologia da Leishmaniose Tegumentar Americana no Brasil, Estados de São Paulo e de Pernambuco. Áreas endêmicas de colonização antiga correspondentes à primária zona de cobertura da mata atlántica".

\section{Manutenção de colônia de triatomíneos em galinheiro experimental:}

O galinheiro experimental vem sendo mantido pelo Laboratório de Criação de Triatomíneos, do Departamento de Epidemiologia, da Faculdade de Saúde Pública-USP, com o propósito de estudar a domiciliação e dinâmica populacional de triatomíneos no município de Araraquara, região do Planalto Ocidental Paulista. Foi instalado em uma área de mata residual localizada no Sítio Carandá, a $12 \mathrm{~km}$ do perímetro urbano desse município. As estruturas foram instaladas na área em meados de 1979 e, desde então, vêm sendo realizadas revisões trimestrais. $O$ galinheiro experimental é formado por trés paredes e teto de sapé de $1 \times 1 \mathrm{~m}$, que internamente é revestido de tijolos de barro sobrepostos na altura de $0,5 \mathrm{~m}$. Esta unidade está contida em um quadrado de $3 \times 3 \mathrm{~m}$ totalmente telado, onde são mantidas 3 aves (um galo e duas galinhas), que servem como fontes de alimentação.

Nas revisões, a instalação interna é desmontada, com o propósito de pesquisar a presença de adultos e ninfas vivas ou mortas, exúvias e ovos férteis e inférteis. Todos os elementos são contados e os adultos e ninfas vivas são identificados nas partes laterais do dorso, por meio de tinta colorida. A cada revisão são trocadas as cores de marcação. Após a revisão, 
as instalações são montadas e os adultos, ninfas e ovos férteis são devolvidos. Uma amostragem de cerca de $30 \%$ do total de adultos e ninfas vivas capturadas são separados aleatoriamente para a pesquisa de tripanossomos nas fezes. No presente estudo, os dados relativos ao galinheiro experimental tiveram maior importância na demonstração do comportamento de domiciliação dos triatomíneos da região.

\section{Capturas de animais silvestres:}

Foram efetuadas capturas de animais de diferentes ordens (Marsupialia, Rodentia e Carnivora) em ambientes florestais internos ou na sua margem, por meio de armadilhas tipo "Tomahawk" modificada e do tipo "Sherman" para roedores. Para as primeiras foram utilizadas como iscas laranja, banana, abacaxi, milho ou mandioca, com pelo menos três tipos de iscas por armadilha, já na segunda foi usada pasta de amendoim (tipo Amendocream). As armadilhas eram montadas no final de tarde e examinadas na manhã do dia seguinte. $O$ acondicionamento dos animais capturados era feito na própria armadilha até o momento da manipulação.

Para cada região foram realizadas capturas bimestrais com duração de uma semana e por um periodo de dois anos. As capturas foram feitas pela Equipe de Campo da Seção de Parasitoses Sistêmicas do Instituto Adolfo Lutz-Central e/ou pela Equipe de Campo do Laboratório de Criação de Triatomíneos do Departamento de Epidemiologia, da Faculdade de Saúde Pública-USP, localizado em Araraquara. As capturas, manejo e transporte dos animais silvestres foram efetuados dentro dos limites 
impostos pelo Instituto Brasileiro do Meio Ambiente e dos Recursos Naturais Renováveis (IBAMA) que concedeu autorização especial à Seção de Parasitoses Sistêmicas do Instituto Adolfo Lutz.

Os animais foram registrados e receberam uma inscrição composta pela letra inicial do município em que foram capturados, seguido de numeração seqüencial para cada região, como especificado abaixo:

\section{Municípios \\ $A=$ Araraquara \\ $E=$ Eldorado \\ $\mathbf{G}=$ Iguape \\ I = llhabela}

\section{Numeração Seqüencial}

$1,2,3,4,5,6,7,8,9, \ldots$

$1,2,3,4,5,6,7,8,9, \ldots$

$1,2,3,4,5,6,7,8,9, \ldots$

$1,2,3,4,5,6,7,8,9, \ldots$

Os animais capturados no municipio de Araraquara foram encaminhados ao Laboratório de Criação de Triatomíneos do Departamento de Epidemiologia, Faculdade de Saúde Pública-USP, onde foram submetidos aos procedimentos para pesquisa de tripanossomos. Após os exames, foram devolvidos à área de origem. Os animais capturados nos municipios de Eldorado, Iguape e llhabela foram remetidos à Seção de Parasitoses Sistêmicas do Instituto Adolfo Lutz-Central, onde foram sacrificados para a pesquisa de infecção natural de Leishmania e Trypanosoma. Em casos de mamíferos, sobretudo de roedores, que necessitaram de identificação mais segura, as carcaças foram fixadas em álcool $70 \%$ e encaminhadas à Seção de Mastozoologia do Museu de Zoologia-USP.

A contenção dos animais foi realizada mediante procedimentos físicos e/ou químicos. Para animais de pequeno porte, a contenção foi feita na própria gaiola ou em tela metálica de arame galvanizado. Para animais de 
médio porte foi por meio de jaula com parede gradeada móvel. A contençăo química foi realizada após a física, tendo como objetivo induzir o animal a um estado de imobilidade suficiente para a realização dos procedimentos pertinentes. As drogas usadas foram: Eter etilico, Cloridrato de Tiletamina (Zoletil), Cloridrato de Cetamina (Ketalar) e o Cloridrato de Xilazina (Rompum). A primeira, aplicada por inalação e as demais, por via intramuscular, isoladas ou em associação, variando a dose conforme a espécie animal e seu peso, seguindo especificaçర̃es constantes nas respectivas bulas. Para o sacrificio, quando necessário, foram usadas as mesmas drogas como anestésicos profundos.

\subsection{Procedimentos específicos para a pesquisa de tripanossomos:}

\subsubsection{Aplicação do Xenodiagnóstico:}

Feita a imobilização do animal, foram colocadas caixas plásticas de $6,5 \times 5,5 \mathrm{~cm}$, contendo ninfas de II ou III estádio de desenvolvimento das espécies Triatoma infestans, Panstrongylus megistus e Rhodnius neglectus, em contato com a pele, na parte lateral do corpo ou na região abdominal, e presas por elásticos ou fitas de borrachas. O número de ninfas constantes em cada caixa e o número de caixas utilizadas dependeu do porte do animal. Assim, para roedores pequenos, uma caixa com 6 ninfas(2 exemplares de cada espécie), outros roedores ou marsupiais jovens, uma caixa com 9 ninfas ( 3 exemplares de cada espécie), e para marsupiais adultos ou carnivoros, duas caixas com 9 ninfas. O período de contato foi de 30 a 45 minutos. As ninfas foram examinadas trinta e sessenta dias após a 
realização do xenodiagnóstico para a pesquisa de tripanossomos nas fezes, obtidas por compressão abdominal. As ninfas, para a realização dos xenodiagnósticos, foram fornecidas pelo Laboratório de Criação de Triatomíneos do Departamento de Epidemiologia da Faculdade de Saúde Pública-USP e pelo Laboratório de Triatomíneos do Instituto Adolfo Lutz.

\subsubsection{Coleta das amostras sangüineas:}

Foram realizadas punções do plexo retro-orbital ou cardíaca em roedores; punções da veia lateral caudal ou cardíaca em marsupiais; punções da veia lateral caudal, ou da veia cefálica ou cardíaca, em carnívoros. As quantidades variaram de 0,5 a $3,0 \mathrm{ml}$, conforme o porte do animal. As amostras, assim obtidas, foram utilizadas para: a) semeadura em meio de cultura bifásico como: Ducrey como fase sólida e "Brain Heart Infusion" (BHI) como fase líquida ou Ducrey e "Liver Infusion Triptose" (LIT) como fase líquida, contendo $50 \mu \mathrm{g} / \mathrm{ml}$ de gentamicina; b) exame direto a fresco; e c) confecção de esfregaços sangüíneos, corados pelo Giemsa.

Nota: As especificações dos meios de cultivo utilizados estão apresentadas no Anexo.

\subsubsection{Coleta de visceras:}

Este procedimento foi realizado para animais capturados nos municípios de Eldorado, Iguape e llhabela que foram submetidos, simultaneamente, aos protocolos de isolamento de espécies de Leishmania e Trypanosoma. Assim, foram obtidos fragmentos de órgãos como: 
coração, fígado e baço para pesquisa de amastigotas pela técnica de impressão de órgãos ("imprint") e pelo cultivo em meio bifásico do material resultante, após maceração ou aspiração das visceras, por meio de agulha e seringa, contendo solução fisiológica estéril.

\section{Isolamento de T. cruzi em animais silvestres:}

Foram utilizados diferentes procedimentos para isolamento: a) Xenocultura (cultivo em meio bifásico do trato intestinal de ninfas infectadas provenientes do xenodiagnóstico), conforme técnica descrita por BISUGO et alii, 1998; b) hemocultivo em meio bifásico; e c) cultivo de fragmentos macerados ou conteúdo do aspirado de vísceras como descrito anteriormente. As culturas foram incubadas a $28{ }^{\circ} \mathrm{C}$ e examinadas semanalmente por trinta dias.

Os isolados, uma vez estabelecidos em cultivos, foram criopreservados. As culturas ricas foi adicionada glicerina neutra estéril na concentração de $10 \%$ e acondicionadas em frascos apropriados para criopreservação e mantidas em geladeira por doze horas e transferidas para freezer a $-70^{\circ} \mathrm{C}$. Depois do completo congelamento, foram armazenadas em nitrogênio líquido.

Para caracterização biológica e molecular, os isolados foram descongelados a $37^{\circ} \mathrm{C}$ e os flagelados cultivados em meio LIT e mantidos em repiques semanais nas mesmas condições de incubação usadas no isolamento primário. 
As amostras receberam os registros dos animais correspondentes, como já assinalado no item 3 , acrescidas pelas siglas correspondentes ao nome não científico dos hospedeiros de origem e da técnica utilizada no isolamento. Abaixo estão assinaladas as especificaçōes adotadas nos registros dos isolados.

Número do animal
A $1,2,3,4,5,6,7,8,9, \ldots$

$$
\mathbf{g}=\text { gambá }
$$$$
\mathbf{r}=\text { roedor }
$$
E $1,2,3,4,5,6,7,8,9, \ldots$
$c=$ cuica
G $1,2,3,4,5,6,7,8,9, \ldots$$$
c=\text { culca }
$$
I $1,2,3,4,5,6,7,8,9, \ldots$

Técnica de isolamento

$X=$ Xenocultura

$\mathbf{P}=$ Hemocultura de Punção cardiaca

F/B = Cultura do material Das visceras

\section{Caracterização biológica dos isolados:}

\subsection{Comportamento da infecção em animais experimentais:}

Tripomastigotas metacíclicos obtidos de meio LIT foram quantificadas em câmara de Neubauer e o inóculo acertado para $3 \times 10^{5}$ flagelados. Os parasitos assim obtidos foram inoculados por via intraperitoneal em quatro ratos Wistar e quatro camundongos BALB/ c, ambas espécies recém desmamadas. Dois animais de cada espécie foram imunodeprimidos, com o objetivo de facilitar o encontro dos flagelados na circulação sangüinea. Como imunodepressor, foi usada a ciclofosfamida (Genuxal-Astra 200mg), por via intraperitoneal, em duas dosagens, uma 24 horas antes da inoculação e outra no momento da aplicação do inóculo. As doses utilizadas foram de $2 \mathrm{mg}$ por camundongo e $3 \mathrm{mg}$ por rato. 
O acompanhamento da infecção, tanto nos animais normais como nos imunodeprimidos, foi feito pelo exame direto de sangue da cauda de cada animal três vezes por semana. A partir da constatação de parasitemia patente, foram realizadas quantificações dos flagelados, conforme preconizado por BRENER, (1962). Estas observações se estenderam, no mínimo, 30 dias para camundongos e 45 dias para os ratos ou até a completa negativação. Foi considerado negativo, 0 animal que não apresentou parasitos em trés exames consecutivos. Os animais, que persistiram com parasitemias negativas, durante o periodo de observação, foram submetidos aos exames de microhematócrito e/ou hemocultura, para deteç̧ão de parasitemias sub-patentes. Foram considerados, como parâmetros, o período pré-patente da infecção, os níveis máximos de parasitemia, a duração da fase aguda (período patente) e a mortalidade.

\subsection{Morfologia dos tripomastigotas sangüineos:}

Uma vez estabelecidos os padrões de infecção de cada isolado, novos animais foram infectados, para estudos da morfologia das formas sangüíneas. Os tipos morfológicos foram estudados, ao longo da infecção experimental, pelo exame direto a fresco do sangue e pelo esfregaço sangüíneo corado pelo Giemsa, sendo classificados em formas delgadas, intermediárias, largas e muito largas, baseados em critérios preconizados por SCHELEMPER et alii (1986). 


\subsection{Pesquisa de amastigotas nos órgãos:}

Para a avaliação da presença de amastigotas em órgãos como: fígado, baço, coração e medula óssea, foram realizadas impressões desses órgãos em lâminas ("imprint") e coradas pelo Giemsa, provenientes de animais de experimentação (camundongos e/ ou ratos) na fase aguda da infecção.

\subsection{Desenvolvimento dos flagelados em meio de cultura:}

Uma alíquota de meio de cultura contendo flagelados, com crescimento de seis dias (cultivo recente), foi lavada por três vezes em "Phosphate Buffered Solution" (PBS), com pH 7.2, e usadas na confecção de esfregaços, para avaliação das formas presentes. A taxa de metaciclogênese foi expressa de maneira qualitativa (+ baixa, ++ moderada e +++ intensa) por meio da observaçăo dos isolados em diferentes períodos de cultivos $(4,7,14,21$ e 28 dias $)$.

\subsection{Desenvolvimento dos flagelados nos vetores:}

Para cada isolado, foram utilizadas ninfas de II ou III estádio de desenvolvimento das espécies: Triatoma infestans, Panstrongylus megistus e Rhodnius neglectus. O número de ninfas variou de 3 a 8 exemplares para cada espécie de triatomíneos. Como fonte de infeç̧ão para os artrópodes, foram usados camundongos BALB/C ou ratos Wistar infectados com $3 \times 10^{5}$ tripomastigotas metacíclicos obtidos de cultura. As ninfas foram alimentadas durante o período patente e, em alguns casos, no 
período sub-patente da infecção nos animais de experimentação e os seus conteúdos intestinais foram examinados após trinta e/ou sessenta dias. $O$ exame da hemolinfa e glândulas salivares, para a pesquisa de tripanossomos, foram realizados após sessenta dias do repasto sangüíneo.

\section{Identiflcação e caracterização molecular:}

\subsection{Extração do DNA total:}

Tripanossomos em meio LIT, na fase exponencial de crescimento, foram lavados em PBS ( $\mathrm{pH} 7.2$ ), por duas vezes, e o sedimento armazenado a $-20^{\circ} \mathrm{C}$ até o momento do uso.

A extração de DNA foi de acordo com o método de OSAKI e CZEKO (1984). Assim, os sedimentos contendo os flagelados foram descongelados em banho de gelo. A eles foram adicionados Tampão Tris Salino-EDTA (SE) (pH 8.0), na proporção de $1 \mathrm{ml}$ para $10^{9}$ tripomastigotas; Lauril Sarcosinato de Sódio (Sarkosil) 10\%; Proteinase K (20ng/ml) e Ribonuclease (RNAse) $(10 \mathrm{ng} / \mathrm{ml})$. As misturas foram incubadas a $55-60{ }^{\circ} \mathrm{C}$, por 2 horas. $\mathrm{Em}$ seguida, submetidas à extração: uma vez com Fenol-Tris; 3 vezes com Fenol-Clorofórmio (1/1); 2 vezes com Clorofórmio-Álcool isoamílico (24/1); e uma vez com Clorofórmio puro. Os DNAs das misturas foram precipitados com Etanol puro, gelado, na presença de Acetato de sódio a $0.3 \mathrm{M}(\mathrm{pH} 7.0)$. Os precipitados foram coletados e transferidos para tubos " "Eppendorf" e lavados com Etanol a $70 \%$. Os "pellets" de DNA foram secos a $37{ }^{\circ} \mathrm{C}$ e dissolvidos em Tampão Tris Clorídrico-EDTA (TE) (pH 8.0) e as concentrações de DNA quantificadas por espectrofotômetro de luz ultra- 
violeta (GeneQuant filtro $320 \mathrm{~nm}$ ). As concentrações foram acertadas para $2 \mu \mathrm{g} / \mu \mathrm{l}$ de solução TE e armazenadas em temperatura de geladeira para uso nas técnicas de PCR e RAPD.

\section{2. "Polimerase Chain Reaction" - PCR:}

\subsubsection{Identificação molecular pelo minicírculo de kDNA:}

Para amplificação de fragmentos de minicirculo de kDNA, foram usados os "primers" P35 e P36, descritos por STURM et alii (1989). Nesta reação, os produtos resultantes apresentam 330 pares de base $(p b)$ de comprimento, que correspondem à amplificação de segmento contendo região específica de minicírculo de kDNA do T. cruzi. As características da reação seguiram conforme protocolo estabelecido por AVILLA et alii (1990). Assim, 50ng de DNA genômico total foram incubados inicialmente a $96{ }^{\circ} \mathrm{C}$ por 2 minutos e adicionados a uma mistura contendo 100ng de cada "primer" (P35 e P36); 200 $\mu \mathrm{M}$ de cada desoxirribonucleosideos trifosfatos (dNTP); $2,5 \mu$ l de tampão da reação; $2,5 \cup$ da enzima Taq DNA Polimerase e; $16,0 \mu l$ de água bidestilada deionizada e autoclavada. As condições de amplificação em termociclador foram as seguintes: $1^{\circ} \mathrm{Ciclo}, 94{ }^{\circ} \mathrm{C}$ por 4 minutos, $55{ }^{\circ} \mathrm{C}$ por 20 segundos e $72{ }^{\circ} \mathrm{C}$ por 1 minuto; $2^{\circ} \mathrm{Ciclo}, 94{ }^{\circ} \mathrm{C}$ por 20 segundos, 55 ${ }^{\circ} \mathrm{C}$ por 20 segundos e $72{ }^{\circ} \mathrm{C}$ por 1 minuto; $3^{\circ} \mathrm{Ciclo}, 94{ }^{\circ} \mathrm{C}$ por20 segundos, $55^{\circ} \mathrm{C}$ por 20 segundos e $72{ }^{\circ} \mathrm{C}$ por 10 minutos. Amostras de $10 \mu \mathrm{l}$ dos produtos de kDNA amplificados foram separados por eletroforese em gel de agarose a $2 \%$, corados com brometo de etidium e visualizados por luz ultravioleta. Amostras de $4 \mu$ l de 100pb DNA Ladder Plus (MBI Fermentas) foram 
utilizadas como marcador de peso molecular. Os produtos amplificados das cepas $\mathrm{Y}$ e $\mathrm{G}$ foram usados como controles na reação.

\subsubsection{Caracterização molecular:}

Para amplificação de parte da região intergênica do gene de mini. exon, foram usados 3 oligonucleotídeos:TC1 GTGTCCGCCACCTCCTTCGGGCC-3'), especifico para isolados de $T$. cruzi, pertencentes à linhagem 1 (conforme nova designação $T$. cruzi II); TC2 (5'-CCTGCAGGCACACGTGTGTGTG-3'), especifico para a linhagem 2 (conforme nova designação $T$. cruzi I); e TCC (5'CCCCCCTCCCAGGCCACACTG-3'), comum aos dois grupos, seguindo o protocolo estabelecido por SOUTO et alii (1996). Para a reação, 100ng de DNA genómico, com incubação inicial a $94{ }^{\circ} \mathrm{C}$ por 1 minuto, foram adicionados a uma mistura contendo $50 \mathrm{ng}$ de cada "primer"; $200 \mu \mathrm{M}$ de cada dNTP; $2,5 \mu \mathrm{l}$ de tampão da reação; $2,5 \cup$ de Taq DNA Polimerase e; $16,0 \mu \mathrm{l}$ de água bidestilada deionizada e autoclavada. As condiçōes de amplificação em termociclador programado foram 27 ciclos de: $94{ }^{\circ} \mathrm{C}$ por 30 minutos; 55 ${ }^{\circ} \mathrm{C}$ por 30 segundos; $72{ }^{\circ} \mathrm{C}$ por 30 segundos e; $72{ }^{\circ} \mathrm{C}$ por 10 minutos. Os produtos amplificados das amostras e controles foram analisados da mesma forma que na reação de PCR para minicírculo de KDNA.

\section{3. "Random Amplification of Polymorphic DNA" - RAPD:}

Foram selecionados arbitrariamente os "primers": 625 (CCGCTGGAGC), 615 (CGTCGAGCGG), 606 (CGGTCGGCCA) e 601 
(CCGCCCACTG), escolhidos de um grupo de aproximadamente vinte "primers" de uso corrente no Laboratório de Taxonomia de tripanossomatídeos, do Departamento de Parasitologia do Instituto de Ciências Biomédicas da USP, utilizados para estudos de polimorfismo e relaçס̃es filogenéticas entre diversos tripanossomatídeos. Os "primers" foram adquiridos da University of British Columbia, Biotechnology Laboratory. Para a reação, 100 ng de DNA genômico, incubados previamente a $95{ }^{\circ} \mathrm{C}$ por 2 minutos foram adicionados a uma mistura contendo 100 ng de cada "primer"; $200 \mu \mathrm{M}$ de cada dNTP; $5 \mu l$ de tampão da reação; $2,5 \cup$ de Taq DNA Polymerase (Pharmacia) e; 50 $\mu$ l de água bidestilada deionizada e autoclavada. As condiçōes de amplificação em termociclador foram as seguintes: 1 ciclo de, $95^{\circ} \mathrm{C}$ por 3 minutos, $37^{\circ} \mathrm{C}$ por 2 minutos e $72{ }^{\circ} \mathrm{C}$ por 2 minutos; 33 ciclos de $95{ }^{\circ} \mathrm{C}$ por 1 minuto, $37{ }^{\circ} \mathrm{C}$ por 2 minutos e $72{ }^{\circ} \mathrm{C}$ por 2 minutos e; 1 ciclo de $95^{\circ} \mathrm{C}$ por 1 minuto, $37^{\circ} \mathrm{C}$ por 2 minutos e $72{ }^{\circ} \mathrm{C}$ por 10 minutos. Os produtos amplificados das amostras e controles foram analisados da mesma forma que na reação de $P C R$ para seqüencias de minicírculo de kDNA e de mini-exon.

Uma estimativa preliminar do polimorfismo entre os isolados foi feita por comparação visual dos diferentes padrões de fragmentos gerados por RAPD.

\subsection{Construção de dendogramas baseados em fragmentos de DNA amplificados por RAPD:}

Para a construção dos dendogramas foram utilizadas as bandas geradas pelos 4 "primers" (625, 615, 606 e 601). Cada banda gerada 
representou um caracter. O conjunto de caracteres foram empregados na construção de matriz de similaridade, utilizando o coeficiente de similaridade de Jaccard (JACCARD, 1908), (Dij= 1- $[\mathrm{c} /(2 \mathrm{~N}-\mathrm{c})]$, onde $\mathrm{c}=$ nümero de bandas comuns entre duas amostras e $N=$ número total de bandas diferentes nas duas amostras. Os dados foram analisados pelo método de Neighbor Joinning (SAITOU e NEI, 1987), disponivel no programa PHYLIP 3.5 (FELSENSTEIN, 1989). Estes dados também foram analisados pelo programa MIX do PHYLIP, onde o relacionamento genético foi estimado segundo o método de Parsimónia de Wagner (LUCKOW e PIMENTEL, 1985). O programa SEQBOOT do PHYLIP foi usado para avaliar a consistência dos agrupamentos "clusters", formados pelo método de Parsimônia, por meio das análises de "bootstrap" (100 replicas). 


\section{RESULTADOS}

1. Avaliação do potencial de domiciliação de triatomíneos:

No municipio de Araraquara, a comprovação da existência de triatomíneos com hábitos de domiciliação foi verificada através da instalação e manutenção de galinheiro experimental. Os dados obtidos tiveram o objetivo de ilustrar esta característica epidemiológica nessa região. Entre maio de 1995 e junho de 1999, período que englobou a fase de captura de animais silvestres na regiāo, foram efetuadas 7 verificaçōes entre a $13^{\circ}$ e a $19^{0}$ revisões. Panstrongylus megistus foi a única espécie a colonizar a instalação. Adultos foram coletados e/ou recuperados nas $13^{\circ}, 14^{\circ}, 15^{\circ}$ e $19^{\circ}$ revisões. Ninfas de diferentes estadios foram coletadas em todas as revisōes, com exceção da $18^{\circ}$, como também as exúvias marcadas e não marcadas. Durante o período de observação do galinheiro experimental não foram encontrados triatomíneos infectados na amostragem examinada (30\%).

\section{Capturas de animais silvestres:}

De março de 1996 a março de 1999, foram capturados e estudados 198 mamiferos pertencentes a 3 ordens (Marsupialia, Carnivora e Rodentia) e 17 gêneros. Da ordem Marsupialia, compuseram o estudo, $47(23,7 \%)$ Didelphis albiventris (gambá), $15(7,6 \%)$ D. marsupialis (gambá, mucura branca), 4(2,0\%) Gracilinanus sp (marmosa), 4(2,0\%) Lutreonila crassicaudata (gambeva, gambá marta), 1(0,5\%) Metachirus 
nudicaudatus (cuica), e 35(17,7\%) Philander opossum (cuica, mucura); da ordem Carnivora, 5(2,5\%) Nasua nasua (coati); e da ordem Rodentia, 28(14,1\%) Akodon montensis (rato da mata, do chão), 1(0,5\%) Cavia aperea (preá), $7(3,5 \%)$ Nectomys squamipes (rato d'água), $1(0,5 \%)$ Echimys (Nelomys) thomasi (cururuá), $3(1,5 \%)$ Oligoryzomys nigripes (ratinho do arroz), 10(5,0\%) Oryzomys sp (rato do arroz, do campo), $7(3,5 \%)$ Oxymycterus quaestor (rato cavador, focinhudo), $14(7,1 \%)$ Proechimys iheringi (rato sauiá, de espinho, fedido, que $n$ ), 3(1,5\%) Rattus norvegicus (rato de esgoto, ratazana), 1(0,5\%) Rattus rattus (rato pardo, do paiol, do telhado), $1(0,5 \%)$ Sciurus ingrami (caxinguelê, serelepe, coaticoco) e $11(5,5 \%)$ roedores não identificados. Os dados de capturas referentes a cada região geográfica estão especificados na Tabela 1. Todos os mamíferos procederam de áreas florestadas das diferentes regiōes, com exceção do exemplar de Rattus rattus e dos três Rattus norvegicus que foram capturados em ambientes próximos aos domicilios em Cordas no município de Eldorado e em Buraco Fundo no município de Ilhabela, respectivamente.

3. Pesquisa de flagelados em animais silvestres:

Dos 198 animais capturados nos quatro municípios, $30(15,1 \%)$ apresentaram flagelados em, pelo menos, um dos procedimentos utilizados. As freqüencias de positividade por municipio foram de $9,9 \%$ (9/91) para os animais capturados no municipio de Araraquara, 31,8\% (7/22) para Eldorado, 4,5\% (1/22) para Iguape e 20,6\% (13/63) para Ilhabela. 
Os resultados das análises de 9 animais silvestres, capturados no município de Araraquara, região do Planalto Ocidental Paulista, e que apresentaram pesquisa positiva para flagelados, estão especificados na Tabela 2. Dos 47 gambás, Didelphis albiventris, capturados nesta região, somente $1(2,1 \%)$ foi positivo para tripanossomos semelhantes a $T$. cruzi Nesse animal, o exame direto e o esfregaço sangüíneo revelaram pequena quantidade de parasitos circulantes. O xenodiagnóstico e hemocultura também foram positivos e o isolamento dos flagelados foi obtido a partir do material originário das duas técnicas. Para as outras espécies de animais silvestres capturadas na região, não foi possível detectar tripanossomos do tipo T. cruzi. No entanto, flagelados semelhantes aos encontrados no subgênero Megatrypanum, com diagnóstico provável de $T$. freitasi, foram observados nos animais da ordem Marsupialia (Figura 3 A). As formas tripomastigotas apresentaram morfologia típica como descrita por HOARE (1972). Assim, os parasitos são grandes e largos, apresentando membrana ondulante bem evidente, cinetoplasto marginal afastado da extremidade posterior e situado próximo ao núcleo oval e de posição mediana em relação ao corpo. Esses tripanossomos foram observados no exame direto e/ou em esfregaços sangüineos de $6(12,8 \%)$ D. albiventris e de $2(100,0 \%)$ marmosas, Gracilinanus sp, capturadas. Dois $D$. albiventris apresentaram flagelados semelhantes a $T$. freitasi nas hemoculturas, porém não foi possível manter esses tripanossomos por repiques sucessivos em meio acelular. 
Os resultados dos exames realizados em 8 animais, capturados no Vale do Ribeira, que apresentaram pesquisa positiva para flagelados estão especificados na Tabela 3. Assim, no municipio de Eldorado, a infecção por tripanossomos foi evidenciada em $6(75,0 \%)$ dos 8 gambás, $D$. marsupialis, e em $1(33,3 \%)$ dos 3 camundongos do mato, Oryzomys sp, capturados. Entre os D. marsupialis, o xenodiagnóstico foi positivo em $3(37,5 \%)$, a hemocultura em $4(50,0 \%)$ e a cultura de material das vísceras e o esfregaço sangüineo em apenas $1(12,5 \%)$. Destes, o parasitismo por $T$. cruzi foi, posteriormente, confirmado em $4(50,0 \%)$ animais. Em dois D. marsupialis, em que apenas as hemoculturas foram positivas, não foi possível a identificação dos flagelados, uma vez que estes não se adaptaram aos cultivos. Já, no único exemplar de Oryzomys sp parasitado, somente o exame direto apresentou formas flageladas e o exame da impressão de baço revelou amastigotas. Neste caso, não foi possivel a identificação segura do agente com base nos resultados das duas técnicas. Dos $3 D$. marsupialis capturados em Iguape, $1(33,3 \%)$ apresentou hemocultura positiva e xenodiagnóstico negativo para tripanossomos. Aqui, também não foi possivel a identificação dos flagelados devido a não adaptação dos mesmos em cultura.

Os dados sobre as análises dos 13 mamiferos, parasitados e capturados no litoral Norte, estão representados na Tabela 4. No município de llhabela, houve maior diversidade de espécies de animais silvestres infectados por tripanossomos. 
Desta maneira, a infecção foi observada em $1(25,0 \%)$ dos 4 gambás, $D$. marsupialis, em $4(11,8 \%)$ das 34 cuicas, Philander opossum, em $7(50,0 \%)$ dos 14 ratos sauiá, Proechimys iheringe, e em um roedor não identificado. O exemplar de $D$. marsupialis parasitado apresentou xenodiagnóstico positivo, mas a hemocultura, o exame direto e os esfregaços sangüineos foram negativos. A identificação posterior do isolado, mostrou tratar-se de $T$. cruzi.

Nos $P$. opossum, tanto o xenodiagnóstico, como a cultura do material de aspirado de visceras e a hemocultura, apresentaram resultados positivos. Cada técnica detectou parasitos em 2(5,9\%) dos animais. As hemoscopias, neste grupo de animais, foram negativas e 0 isolamento de $T$. cruzi foi possivel pelos três procedimentos em $3(8,8 \%)$ P. opossum. Em um animal com hemocultura positiva, a identificação dos tripanossomos não foi possível porque os flagelados não se mantiveram em meio de cultura.

Entre os Proechimys iheringe, o xenodiagnóstico foi positivo em $3(21,4 \%)$, a hemocultura em $1(7,1 \%)$, a cultura do aspirado de figado e baço em $1(7,1 \%)$ e o exame hemoscópico em $4(28,6 \%)$. O isolamento do $T$. cruzi foi obtido apenas pelo material do xenodiagnóstico em dois Proechimys. No animal com hemocultura positiva não foi possivel 0 isolamento dos flagelados por falta de adaptação ao cultivo. Neste caso, o exame do esfregaço sangüineo revelou a presença de inumeras formas tripomastigotas, características do subgênero Herpetosoma, isto é, formas finas de tamanho médio, apresentando membrana ondulante estreita e flagelo livre longo, cinetoplasto bem evidente situado próximo a extremidade 
posterior e núcleo ocupando uma posição mais anterior ao corpo (Figura 3 B). Por outro lado, dois animais apresentaram tripanossomos somente ao exame de sangue direto, não sendo encontrado tripomastigotas nos esfregaços sangüíneos. Em outro Proechimys, foi isolado flagelado a partir do material de cultivo de aspirado de órgãos. Neste caso, o comportamento biológico do isolado em meio de cultura acelular e infecção em hamsters mostrou tratar-se do gênero Leishmania. No roedor de espécie não identificada, a hemocultura e a hemoscopia foram positivas, porém năo se conseguiu o isolamento dos flagelados em meio de cultivo acelular. Contudo, as formas tripomastigotas, encontradas nos esfregaços sangülneos deste animal, foram semelhantes àquelas encontradas no subgénero Herpetosoma (Figura 3 B).

\subsection{Isolamento de T. cruzi em animais silvestres:}

As especificações de cada isolado, com as respectivas espécies de hospedeiros de origem, os tipos de procedimentos usados no isolamento e as origens geográficas constam na Tabela 5. Assim, considerando todas as regiões estudadas, foram isoladas 16 amostras de $T$. cruzi a partir de 11 animais silvestres, sendo 1 Didelphis albiventris, 5 D. marsupialis, 3 Philander opossum e, 2 Proechimys iheringe. Dos 16 isolados, 9(56,2\%) foram obtidos pela xenocultura, $4(25,0 \%)$ pela hemocultura e $3(18.7 \%)$ pela cultura do material aspirado de fígado e baço. Em 1 D. marsupialis, foram isolados flagelados pelas três metodologias; já em $1 \boldsymbol{D}$. albiventris e $2 \boldsymbol{P}$. opossum, os parasitas foram isolados por dois dos procedimentos 
(xenocultura e hemocultura; xenocultura e cultura do aspirado ou hemocultura e cultura do aspirado) e, em $4 D$. marsupialis, $1 P$. opossum e nos $2 \boldsymbol{P}$. iheringe, 0 isolamento ocorreu pela xenocultura ou pela hemocultura.

\section{Caracterização biológica dos isolados:}

\subsection{Comportamento da infecção em animais experimentais:}

O comportamento da infecção em camundongos BALB/c e ratos Wistar, recém desmamados, normais ou imunodeprimidos pela ciclofosfamida estão expressos nas Tabelas $6,7,8$ e 9 . Os niveis de parasitemias máximos e períodos pré-patente e patente, mínimos e máximos e a mortalidade variaram nos diferentes isolados e, também, conforme a espécie de animal de laboratório, normal ou imunodeprimido, utilizado no estudo. Nas Figuras 4 e 5 estăo representados graficamente os tipos de infecção, patente ou sub-patente, determinados pelas amostras de T. cruzi, isoladas de animais silvestres, de diferentes gêneros em camundongos BALB/C e em ratos Wistar normais ou imunodeprimidos.

A evolução da infecção das diferentes amostras de $T$. cruzi em camundongos $B A L B / C$, que não foram submetidos ao esquema de imunodepressão está assinala na Tabela 6 . Nesses animais, as amostras Ag5P, Ag5X e Eg23F/B, isoladas de Didelphis, não produziram infecção patente, sendo que os exames de sangue (direto e microhematócrito) mantiveram-se negativos durante o periodo de trinta dias de observação. Hemoculturas realizadas após este tempo, também foram negativas. Da 
mesma maneira, nas amostras, Eg23P, Eg24X, Eg31P e Eg32X, também isoladas de Didelphis, os exames de sangue foram negativos, entretanto foi possivel detectar parasitemias sub-patentes por meio de hemocultura realizada ao final do $30^{\circ}$ dia após a inoculação. Já em dois isolados de Didelphis (Eg23X e Ig42X), nos dois de Proechimys (Ir12X, Ir14X) e nos cinco de Philander (Ic70X, Ic74P, Ic74F/B, Ic76X e Ic76F/B), as parasitemias foram patentes. As parasitemias máximas não alcançaram níveis elevados, ocorrendo entre $012^{\circ}$ e $18^{\circ}$ dia após a infecção nos diferentes isolados. Os períodos pré-patente mínimos e máximos observados na infecção de camundongos normais foram de 5 e 7 dias para os isolados Ir14X e Ic74F/B; 7 e 10 dias para IC76F/B; e 9 dias ou de 9 e 12dias para as demais amostras. O periodo patente variou de, no mínimo, 11 dias, como observado no isolado Ic70X e, no máximo, de 42 dias, como na amostra Eg23X. A mortalidade foi nula para um período de acompanhamento de 69 dias.

Os dados da infecção dos diferentes isolados em camundongos BALB/c submetidos à imunodepressão pela ciclofosfamida estão relacionados na Tabela 7 . Nesses animais, o comportamento dos isolados, de maneira geral, foi semelhante ao dos camundongos normais. No entanto, diferiu nos níveis de parasitemias máximas que foram mais elevadas, na ligeira redução do período pré-patente e patente em alguns isolados e no índice de mortalidade. Vale ressaltar que a imunodepressão não alterou o comportamento dos isolados Ag5P, Ag5X, Eg23P, Eg23F/B, Eg24X, Eg31P 
e Eg32X. No isolado Eg31P, a morte de um animal, sem parasitemia patente, provavelmente ocorreu devido a fatores não ligados à infecção.

A evolução da infecção das diferentes amostras de $T$. cruzi em ratos Wistar normais está assinalada na Tabela 8 . Todas as amostras foram infectantes para estes animais, porém, nota-se que, nos isolados de Didelphis, Ag5P e Ag5X, os parasitos produziram infecção sub-patente, sendo os flagelados detectados ao longo de 45 dias de observação, pela técnica do microhematócrito. Para os isolados de Didelphis, Eg23F/B, Eg32X, Ig42X, de Proechimys, Ir12X e de Philander, Ic70X, Ic74P e IC74F/B foram observadas parasitemias de baixa intensidade, atingindo o valor máximo de 40 tripomastigotas sangüíneos/ $5 \mathrm{~mm}^{3}$. Porém, nas amostras Eg23F/B, Ig42X e Ic74F/B essas parasitemias se apresentaram de maneira descontínua ao longo das observaçőes realizadas. As parasitemias máximas dos outros isolados também não alcançaram niveis elevados. O pico parasitêmico foi verificado entre $012^{\circ}$ e $35^{\circ}$ dia após a infecção. Os periodos pré-patente mínimos e máximos, observados na infecção de ratos normais, foram diferentes entre as amostras, variando de, no mínimo, 7 dias e, no máximo, 19 dias. A duração da fase aguda variou de, no mínino, 5 a 7 dias, como observada nos isolados Ic70X, Ir12X e Ir14X e, de, no máximo, 26 dias, como nas amostras Eg24X e Ic74P. Não foi observada mortalidade neste grupo para um periodo de acompanhamento de 62 dias.

Os dados da infecção dos diferentes isolados em ratos Wistar submetidos à imunodepressão pela ciclofosfamida são mostrados na Tabela 
9. Aqui, também, o comportamento não diferiu muito dos ratos normais. Assim, houve diferenças quanto aos níveis de parasitemia máxima que, nestes animais, foram mais elevadas, exceto para o isolado Ig42X que apresentou parasitemia baixa e intermitente, năo permitindo estimar os periodos pré-patente e patente. Não houve, de maneira geral, alteração do período pré-patente, porém observa-se ligeiro aumento da duração da fase aguda. A mortalidade foi quase que inexistente, sendo registrada a morte de um único animal infectado com a amostra Ic74P.

\subsection{Morfologia dos tripomastigotas sangüíneos:}

Os tipos morfológicos dos tripomastigotas sangüíneos encontrados foram: formas delgadas, intermediárias, largas e muito largas. A Figura 6 mostra o polimorfismo observado entre tripomastigotas sangüíneos de $T$. cruzi dos diferentes isolados de animais silvestres.

As formas delgadas representaram tripomastigotas finas, de traçado sinuoso, núcleo alongado, cinetoplasto muito afastado da extremidade posterior, membrana ondulante não evidente e flagelo livre, continuando com a parte anterior sem apresentar limite nítido.

As formas intermediárias constituiram-se de tripomastigotas pouco mais largas que a forma anterior e de traçado menos sinuoso, núcleo alongado por vezes ovóide, cinetoplasto pouco afastado da extremidade posterior, membrana ondulante mais evidente e flagelo livre, continuando com a parte anterior apresentando limite nítido. 
As formas largas foram caracterizadas por tripomastigotas em forma de " $C$ ", às vezes de " $S$ ", com núcleo esférico ou ligeiramente ovóide de posição mediana, cinetoplasto junto a extremidade posterior, membrana ondulante bem definida e flagelo longo e nítido.

As formas muito largas mostraram caracteristicas comuns às anteriores, destacando-se por apresentar maior largura, citoplasma intensamente vacuolizado e núcleo, na maioria das vezes, situado na posição anterior.

O encontro dos tipos morfológicos das tripomastigotas sangüíneos na infecção experimental de cada isolado está assinalado na Tabela 10. As formas intermediárias e largas foram observadas na infecção experimental de todos os isolados com exceção dos Ag5P e Ag5X que apresentaram só formas largas. Nestes isolados, formas largas foram encontradas em esfregaços do creme leucocitário mediante o emprego da técnica do microhematócrito. Dentre todas as amostras, a Eg23X foi a única que apresentou as formas delgadas "clássicas". Tanto as formas delgadas quanto as formas intermediárias foram observadas no inicio da fase aguda da infecção, desaparecendo em seguida da circulação, quando prevaleceram as formas largas até o final do período patente. Formas muito largas foram observadas, sobretudo, em amostras isoladas de Didelphis, cujo aparecimento se fez tardiamente.

\subsection{Pesquisa de amastigotas nos órgãos:}


O parasitismo tissular foi estudado em camundongos e ratos, submetidos ao esquema de imunodepressão proposto, inoculados e examinados na fase aguda da infecção pela técnica de impressão de órgãos. Em todas as amostras de tripanossomos estudadas foram encontradas amastigotas em pelo menos um dos órgãos. Os dados referentes ao parasitismo tecidual estão assinalados na Tabela11.

Dos 16 isolados, $15(93,7 \%)$ apresentaram amastigotas no coração. Somente o isolado Ag5P não apresentou formas teciduais no referido órgão. De maneira geral, o parasitismo no coração foi baixo, sendo encontradas amastigotas isoladas ou agrupadas em pequeno número. No entanto, nas amostras Eg23X, Eg23P e Eg31P, todas de Didelphis, o parasitismo cardiaco variou de moderado a intenso, sendo observadas amastigotas livres ou no citoplasma de macrofagos (Figura 7 A, B, C, D). Já nos isolados de Proechimys e Philander, as amastigotas evidenciadas em todas as preparações de coração, foram sempre em pequeno número.

$\mathrm{Na}$ medula óssea, foram observadas amastigotas livres ou intracelulares em $11(68,7 \%)$ isolados (Figura 7 E, F). Nota-se que houve uma maior frequeencia dos parasitos nas amostras de Proechimys e Philander. Assim, entre as 7 amostras deste grupo, $6(85,7 \%)$ apresentaram amastigotas. No entanto, a intensidade parasitária foi baixa, exceto para o isolado Ic70X que apresentou parasitismo moderado. Dos 9 isolados de Didelphis, 5 (55,5\%) apresentaram amastigotas nesse órgão. Aqui, somente a amostra Eg23X mostrou parasitismo de intensidade moderada, sendo pequeno o número de parasitos encontrados nas demais amostras. 
No fígado, também foram observadas amastigotas livres ou intracelulares em $9(56,2 \%)$ isolados. Parasitismo mais freqüente e intenso foi observado nas amostras de tripanossomos isolados de Proechimys e Philander que, de 7 amostras, foram detectadas amastigotas em 6 (85,7\%). A intensidade parasitária foi variada, sendo intensa nas amostras Ir14X e Ic70X, moderada na amostra Ic76X e baixa nas demais. Entre os isolados de Didelphis, apenas $3(33,3 \%)$ apresentaram o parasito neste órgão. $\mathrm{Na}$ amostra Eg23X o parasitismo foi moderado, sendo baixo nas amostras Eg23P e Eg31P.

Neste estudo, o baço foi o órgão menos parasitado, sendo evidenciado o parasitismo em $8(50,0 \%)$ dos isolados. Das 7 amostras de Proechimys e Philander, 4 (57,1\%) apresentaram amastigotas. Parasitismo moderado foi observado nos isolados Ir14X e Ic70X, sendo que, nas outras duas amostras, a intensidade parasitária foi baixa. Em Didelphis, 4 (44,4\%) dos isolados foram positivos para a presença de amastigotas. Nesse grupo, apenas a amostra Eg23X apresentou intensidade parasitária moderada com a presença de macrófagos contendo amastigotas. Para as outras amostras positivas (Ag5P, Eg31P e Eg32X) o parasitismo foi baixo.

\subsection{Desenvolvimento dos flagelados em meio de cultura:}

No isolamento primário a partir de materiais originários do xenodiagnóstico, da punção cardíaca e do aspirado de figado e baço, as 16 amostras apresentaram boa adaptação ao cultivo em meios bifásicos. Posteriormente, todos os isolados foram mantidos em meio LIT com repiques semanais. No isolado Ig42X, houve, inicialmente, uma maior 
dificuldade na adaptação dos flagelados em meio LIT, exigindo cuidados adicionais como agitação contínua durante a fase de crescimento e suplementação de soro fetal bovino. Os exames microscópicos diretos ou por meio de esfregaços corados pelo Giemsa, realizados em cultivos recentes, após um periodo de adaptação, revelaram crescimento exuberante em rosetas e inúmeras formas epimastigotas em fase de divisão (Figura 8 A). Houve acentuado polimorfismo das epimastigotas em todos os isolados. Os tipos morfológicos variaram entre formas epimastigotas longas e largas; longas e finas; médias e pequenas (Figura $8 \mathrm{~A}, \mathrm{~B}, \mathrm{C}$ ).

As formas tripomastigotas metacíclicas apresentaram dimorfismo evidente, sendo observados tipos celulares grandes com membrana ondulante, por vezes, destacada do corpo e metacíclicos de tamanho médio (Figura $8 \mathrm{D}, E, F$ ). $O$ primeiro tipo foi predominante nos isolados de Didelphis, com exceção das amostras Eg23X e Ig42X; o segundo, encontrado nos demais isolados. Houve nítida diferença na taxa de metaciclogênese entre os diferentes isolados, como mostra a Tabela12. De maneira geral, a diferenciação das formas epimastigotas em tripomastigotas metacíclicas ocorreu mais precocemente na maioria das amostras de Didelphis, sendo iniciada a partir do $4^{\circ}$ dia de cultivo e alcançando intensa diferenciação no $14^{\circ}$ dia. Este comportamento não foi observado para os isolados de Didelphis, Eg23X e Ig42X e para o isolado de Philander, Ir12X, que apresentaram baixa taxa de metaciclogênese ao longo de todo o período de observação. Para as demais amostras, a metaciclogênese 
ocorreu de forma mais lenta, alcançando diferenciação de moderada a intensa no $28^{\circ}$ dia de cultivo.

\subsection{Desenvolvimento dos flagelados nos vetores:}

Todos os isolados evoluíram no tubo intestinal das três espécies de triatomineos ( $T$. infestans, $R$. neglectus e $P$. megistus), apresentando tripomastigotas metacíclicas nas fezes destes vetores, 30 ou 60 dias após a aplicação do xenodiagnóstico nos animais de experimentação inoculados com os diferentes isolados de $T$. cruzi. O número de ninfas positivas em relação ao número de ninfas aplicadas por espécies de triatomíneos e respectivo percentual de positividade está apresentada na Tabela 13. Exames da hemolinfa e da glândula salivar realizados nestes triatomíneos não revelaram a presença de outros flagelados.

Os percentuais de positividade do xenodiagnóstico aplicados nos animais de experimentação variaram conforme as espécies de triatomíneos usados e entre as amostras de tripanossomos estudadas. Os indices gerais de infectividade para as três espécies de triatomineos foram de $50,7 \%$, $49,3 \%$ e $50,7 \%$ para Triatoma infestans, Rhodnius neglectus e Panstrongylus megistus, respectivamente. Já, as taxas de positividade do xenodiagnóstico em relação às amostras de flagelados, variaram de $33,3 \%$ para os isolados Eg23X e Eg23F/B a 77,7\% para o isolado IC74F/B. 


\section{Identificação e caracterização molecular:}

Para a identificação e caracterização molecular, foram usadas as 16 amostras de DNA dos isolados primários. Dados complementares sobre o hospedeiro de origem, técnica de isolamento e municipio procedente, estão assinalados na Tabela 5, como já mencionado anteriormente. Como controle, foram utilizadas amostras de DNA da cepa G, isolada de marsupial da região amazônica e da cepa $Y$, isolada de caso humano. Portanto, foram usados controles representativos dos ciclos de transmissão silvestre e domiciliar.

\subsection{Identificação molecular pelo minicírculo de kDNA:}

A amplificação de seqüência de minicírculo de KDNA, foi utilizada com o objetivo de confirmar o diagnóstico de $T$. cruzi. Os resultados dos produtos amplificados pela técnica de PCR, utilizando-se os "primers" P35 e P36 são mostrados na Figura 9. A banda de $330 \mathrm{pb}$, característica de $T$. cruzi, foi obtida nas 16 amostras de tripanossomos, incluindo os dois controles. Este dado aliado com os dos parâmetros biológicos identificam todos os isolados analisados como sendo $T$. cruzi. Além do fragmento de $330 \mathrm{pb}$, um produto de aproximadamente $400 \mathrm{pb}$ foi amplificado em todas as amostras, com exceção da cepa Y, utilizada como controle.

\subsection{Caracterização molecular:}

\subsubsection{PCR de gene de mini-exon:}


A caracterização molecular foi baseada na amplificação, pela técnica de PCR, de um segmento da região intergênica do gene de mini-exon, que define o dimorfismo genético no grupo T. cruzi. A Figura 10 mostra os produtos resultantes desta reação. Os genótipos, T. cruzi I e T. cruzi ॥ relativos às 16 amostras isoladas estão assinalados na Tabela 14.

Houve diferenças na distribuição dos tipos genéticos, conforme a espécie de hospedeiro e sua origem geográfica. Assim, as amostras Ag5X e Ag5P, isoladas de um mesmo marsupial da espécie D. albiventris capturado no município de Araraquara, apresentaram banda de $350 \mathrm{pb}$, que caracteriza a linhagem de $T$. cruzi I. Das 6 amostras isoladas de $D$. marsupialis capturados no município de Eldorado, Vale do Ribeira, 5 apresentaram a banda de $350 \mathrm{pb}$ e, em apenas uma amostra, o produto de PCR foi de $300 \mathrm{pb}$, característico da linhagem T. cruzi II. Cabe ressaltar que, nas amostras Eg23X, Eg23P e Eg23F/B, isoladas de um mesmo $D$. marsupialis, foi identificada a banda de $300 \mathrm{pb}$ para a primeira amostra e de $350 \mathrm{pb}$ para a segunda e terceira amostra, respectivamente. Das 8 amostras de tripanossomos originários do municipio de Ilhabela, Litoral Norte, somente a amostra Ig42X, isolada de um D. marsupialis, apresentou banda de 300 pb. Os isolados de Proechimys e de Philander não apresentaram as bandas esperadas de 300 ou $350 \mathrm{pb}$. No entanto, foram obtidos nestas amostras bandas de aproximadamente $100 \mathrm{pb}$, mostrando que esses isolados não pertencem a nenhuma das linhagens descritas. 


\subsubsection{Polimorfismo pelo RAPD:}

Os perfis de bandas produzidas pela técnica de RAPD foram também utilizadas na caracterização molecular dos 16 isolados de animais silvestres. Os padrões de bandas obtidas com os "primers" 625, 615, 606 e 601 são mostrados nas Figuras $11 \mathrm{~A}, 11 \mathrm{~B}, 12 \mathrm{~A}$ e $12 \mathrm{~B}$

As análises comparativas dos fragmentos amplificados por RAPD revelaram diferentes padrões conforme o "primer" utilizado. Assim, o padrão obtido pelo "primer" 606 mostrou pequena heterogeneidade entre os isolados com o compartilhamento de dois fragmentos de aproximadamente $550 \mathrm{pb}$ e $650 \mathrm{pb}$, comuns a todos os isolados, incluíndo os controles da cepa G e Y (Figura 12 A). Padrões mais polimorficos, apresentando diferenças no número e no tamanho dos fragmentos amplificados, foram obtidos com os "primers" 625 e 615 . Esses padrões permitiram distinguir os isolados pela espécie de hospedeiro e pelos tipos genéticos, definidos na caracterização molecular pelo gene de mini-exon (Figuras 11 A e 11 B). Já, pelo perfil de bandas produzidas pelo "primer" 601 foi possivel separar as amostras de $T$. cruzi pela origem geográfica, independente da espécie de hospedeiro (Figura 12 B).

\subsubsection{Análise do relacionamento genéticos através dos dendogramas:}

Os quatro "primers" usados na técnica de RAPD geraram um total de 70 bandas (caracteres) que foram empregados na construção de matriz de similaridade para estudo do relacionamento genética. Os dendogramas obtidos pelos métodos de análises Neighbor Joinning e de Parsimônia de 
Wagner apresentaram a mesma topologia. A topologia do dendograma e respectivos valores de "bootstrap" obtidos a partir do método de Parsimônia de Wagner estão assinalados na Figura 13. Os percentuais de similaridade entre os "clusters" de $T$. cruzi estão expressos na Tabela 15.

A análise da topologia do dendograma e dos valores de "bootstrap" de 100 replicas separaram as amostras de $T$. cruzi, isoladas de animais silvestres em três "clusters" (A, B e C). As amostras Eg23X e Ig42X, do tipo genético T. cruzi II, proveniente de Didelphis, capturados nos municipios de Eldorado e Ilhabela, respectivamente, não foram agrupadas nesta análise (Figura 13).

O "cluster" A incluiu todas as amostras isoladas de Proechimys e de Philander originárias do município de llhabela e, com genótipo não definido pelo gene de mini-exon. O valor de "bootstrap" para essas amostras correspondeu a $96 \mathrm{com}$ índice de similaridade de $72 \%$ entres elas. Nesse grupo, os isolados foram sub-divididos em dois sub-“clusters”, um formado pelas duas amostras isoladas de Proechimys e, o outro formado pelas cinco amostras isoladas de Philander.

O "cluster" B foi constituido pelas cinco amostras do tipo T. cruzi I, isoladas de Didelphis capturados no municipio de Eldorado. Esse grupo apresentou valor de "bootstrap" de 86 e indice de similaridade de $82 \%$.

O "cluster" C apresentou valor de "boostrap" de 96 e percentual de similaridade de $100 \%$, sendo constituído pelas duas amostras do tipo $T$. cruzi I, isoladas do mesmo animal capturado no municipio de Araraquara. O controle cepa $G$, também do tipo $T$. cruzi I, isolada de Didelphis da regiāo 
Amazônica apresentou percentual de similaridade de $54 \%$ em relação aos isolados de Araraquara, indicando um maior relacionamento genético com o "cluster" C (Tabela 15). 
V. TABELAS E FIGURAS 
Tabela 1. Número $(N)$ e percentual $(\%)$ de espécies de mamiferos capturados nos municípios de Araraquara (Planalto Ocidental Paulista), Eldorado e Iguape (Vale do Ribeira e lihabela (Litoral norte), Estado de São Paulo, Brasil, no período de março de 1996 a março de 1999.

\begin{tabular}{|c|c|c|c|c|c|c|c|c|c|c|}
\hline \multirow{3}{*}{ Mamiferos } & \multicolumn{8}{|c|}{ Municípios } & & \\
\hline & \multicolumn{2}{|c|}{ Araraquara } & \multicolumn{2}{|c|}{ Eldorado } & \multicolumn{2}{|c|}{ Iguape } & \multicolumn{2}{|c|}{ Ilhabela } & \multicolumn{2}{|c|}{ Total } \\
\hline & $\mathbf{N}$ & $(\%)$ & $\mathbf{N}$ & $(\%)$ & $\mathbf{N}$ & $(\%)$ & $\mathbf{N}$ & $(\%)$ & $\mathbf{N}$ & $(\%)$ \\
\hline Didelphis albiventris & \multicolumn{2}{|c|}{$47(51,6)$} & \multirow{2}{*}{\multicolumn{2}{|c|}{$8(36,4)$}} & \multirow{2}{*}{\multicolumn{2}{|c|}{$\begin{array}{l}0(0,0) \\
3(13,6)\end{array}$}} & \multirow{2}{*}{\multicolumn{2}{|c|}{$\begin{array}{ll}0 & (0,0) \\
4 & (6,3)\end{array}$}} & \multicolumn{2}{|c|}{$47(23,7)$} \\
\hline Didelphis marsupialis & 0 & $(0,0)$ & & & & & & & 15 & $(7,6)$ \\
\hline Gracillinanus sp & 2 & $(2,2)$ & & $(4,5)$ & 0 & $(0,0)$ & 1 & $(1,6)$ & 4 & $(2,0)$ \\
\hline Lutreonila crassicaudata & 4 & $(4,4)$ & 0 & $(0,0)$ & 0 & $(0,0)$ & 0 & $(0,0)$ & 4 & $(2,0)$ \\
\hline Motachirus nudicaudatus & 0 & $(0,0)$ & 0 & $(0,0)$ & 1 & $(4,5)$ & 0 & $(0,0)$ & 1 & $(0,5)$ \\
\hline Philander opossum & 0 & $(0,0)$ & 0 & $(0,0)$ & 1 & $(4,5)$ & \multicolumn{2}{|c|}{$34(54,0)$} & \multicolumn{2}{|c|}{$35(17,7)$} \\
\hline Nasua nasua & 5 & $(5,5)$ & 0 & $(0,0)$ & 0 & $(0,0)$ & 0 & $(0,0)$ & 5 & $(2,5)$ \\
\hline Akodon montensis & \multicolumn{2}{|c|}{$19(20,9)$} & \multirow{2}{*}{\multicolumn{2}{|c|}{$\begin{array}{ll}2 & (9,1) \\
0 & (0,0)\end{array}$}} & \multicolumn{2}{|c|}{$7(31,8)$} & 0 & $(0,0)$ & 28( & $(14,1)$ \\
\hline Cavia aperea & 0 & $(0,0)$ & & & 0 & $(0,0)$ & 1 & $(1,6)$ & 1 & $(0,5)$ \\
\hline Nectomys squamipes & 7 & $(7,7)$ & 0 & $(0,0)$ & 0 & $(0,0)$ & 0 & $(0,0)$ & 7 & $(3,5)$ \\
\hline Echimys thomasi & 0 & $(0,0)$ & 0 & $(0,0)$ & 0 & $(0,0)$ & 1 & $(1,6)$ & 1 & $(0,5)$ \\
\hline Oligoryzomys nigripes & 3 & $(3,3)$ & 0 & $(0,0)$ & 0 & $(0,0)$ & 0 & $(0,0)$ & 3 & $(1,5)$ \\
\hline Oryzomys sp & 0 & $(0,0)$ & & $(13,6)$ & & $(31,8)$ & 0 & $(0,0)$ & 10 & $(5,0)$ \\
\hline Oxymycterus quaestor & 0 & $(0,0)$ & 1 & $(4,5)$ & & $(13,6)$ & 3 & $(4,8)$ & 7 & $(3,5)$ \\
\hline Proechimys iheringi & 0 & $(0,0)$ & 0 & $(0,0)$ & 0 & $(0,0)$ & & $(22,2)$ & 14 & $(7,1)$ \\
\hline Rattus norvegicus & 0 & $(0,0)$ & 0 & $(0,0)$ & 0 & $(0,0)$ & 3 & $(4,8)$ & 3 & $(1,5)$ \\
\hline Rattus rattus & 0 & $(0,0)$ & 1 & $(4,5)$ & 0 & $(0,0)$ & 0 & $(0,0)$ & 1 & $(0,5)$ \\
\hline Sciurus ingrami & 0 & $(0,0)$ & 0 & $(0,0)$ & 0 & $(0,0)$ & 1 & $(1,6)$ & 1 & $(0,5)$ \\
\hline Roedores não identificados & 4 & $(4,4)$ & & $(27,3)$ & 0 & $(0,0)$ & 1 & $(1,6)$ & 11 & $(5,5)$ \\
\hline Total por municipios & $91(1$ & $100,0)$ & 22( & $100,0)$ & 22( & $100,0)$ & 63( & $(100,0)$ & 198( & $(100,0)$ \\
\hline
\end{tabular}


Tabela 2. Resultados da hemoscopia (direto e esfregaço sangüíneo), "imprint" de órgãos (coração, fígado e baço), cultura de órgãos (fígado e baço), hemocultura e xenodiagnóstico de nove animais silvestres, capturados no município de Araraquara (Planalto Ocidental Paulista), Estado de São Paulo, Brasil, que apresentaram pesquisa positiva para flagelados.

\begin{tabular}{|c|c|c|c|c|c|c|c|}
\hline $\begin{array}{c}\text { Registro } \\
\text { do } \\
\text { Animal }\end{array}$ & Espécie & Hemoscopia & "Imprint" & $\begin{array}{c}\text { Cultura } \\
\text { de } \\
\text { órgãos }\end{array}$ & Hemocultura & $\begin{array}{l}\text { Xeno- } \\
\text { diagnóstico }\end{array}$ & Flagelados \\
\hline A4 & Didelphis albiventris & + & $\mathrm{Nr}$ & $\mathrm{Nr}$ & Neg & Neg & T. freitasi (?) \\
\hline A5 & Didelphis albiventris & + & Neg & Neg & $+*$ & $+*$ & T.cruzi \\
\hline A24 & Gracilinanus sp & + & Neg & Neg & Neg & Neg & T. freitasi (?) \\
\hline A30 & Gracilinanus sp & + & Neg & Neg & Neg & Neg & T. freitasi (?) \\
\hline A55 & Didelphis albiventris & + & $\mathrm{Nr}$ & $\mathrm{Nr}$ & Neg & Neg & T. freitasi (?) \\
\hline A66 & Didelphis albiventris & + & $\mathrm{Nr}$ & $\mathrm{Nr}$ & Neg & Neg & T. freitasi (?) \\
\hline A82 & Didelphis albiventris & + & $\mathrm{Nr}$ & $\mathrm{Nr}$ & Neg & Neg & T. freitasi (?) \\
\hline A111 & Didelphis albiventris & + & $\mathrm{Nr}$ & $\mathrm{Nr}$ & + & $\mathrm{Neg}$ & T. freitasi (?) \\
\hline A112 & Didelphis albiventris & Neg & $\mathrm{Nr}$ & $\mathrm{Nr}$ & + & Neg & T. freitasi (?) \\
\hline
\end{tabular}

Neg = negativo

$\mathrm{Nr}=$ exame năo realizado

* amostra isolada

(?) diagnóstico provável baseado em critérios morfológicos e/ou biológicos 
Tabela 3. Resultados da hemoscopia (direto e esfregaço sangüíneo), "imprint" de órgãos (coração, fígado e baço), cultura de órgãos (fígado e baço), hemocultura e xenodiagnóstico de oito animais silvestres, capturados nos municípios de Eldorado e Iguape (Vale do Ribeira), Estado de São Paulo, Brasil, que apresentaram pesquisa positiva para flagelados.

\begin{tabular}{|c|c|c|c|c|c|c|c|}
\hline $\begin{array}{c}\text { Registro } \\
\text { do } \\
\text { Animal }\end{array}$ & Espécie & Hemoscopia & "Imprint" & $\begin{array}{c}\text { Cultura } \\
\text { de } \\
\text { órgäos }\end{array}$ & Hemocultura & $\begin{array}{l}\text { Xeno- } \\
\text { diagnóstico }\end{array}$ & Flagelados \\
\hline E23 & Didelphis marsupialis & + & Neg & $+*$ & $+*$ & $+*$ & T.cruzi \\
\hline E24 & Didelphis marsupialis & Neg & Neg & Neg & Neg & $+*$ & T. cruzi \\
\hline E27 & Oryzomys sp & + & + & Neg & Neg & Neg & T. cruzi (?) \\
\hline E29 & Didelphis marsupialis & Neg & Neg & Neg & + & Neg & Sd \\
\hline $\mathrm{E} 30$ & Didelphis marsupialis & Neg & Neg & Neg & + & $\mathrm{Neg}$ & Sd \\
\hline E31 & Didelphis marsupialis & + & Neg & Neg & $+\star$ & Neg & T. cruzi \\
\hline E32 & Didelphis marsupialis & $\mathrm{Neg}$ & Neg & Neg & Neg & $+*$ & T. cruzi \\
\hline G5 & Didelphis marsupialis & Neg & Neg & Neg & + & $\mathrm{Neg}$ & Sd \\
\hline
\end{tabular}

Neg = negativo

Sd = sem diagnóstico

* amostra isolada

(?) diagnóstico provável baseado em critérios morfológicos e/ou biológicos 
Tabela 4. Resultados da hemoscopia (direto e esfregaço sangüíneo), "imprint" de órgãos (coração, fígado e baço), cultura de órgãos (fígado e baço), hemocultura e xenodiagnóstico de treze animais silvestres, capturados no município de llha Bela (Litoral Norte), Estado de São Paulo, Brasil, que apresentaram pesquisa positiva para flagelados.

\begin{tabular}{|c|c|c|c|c|c|c|c|}
\hline $\begin{array}{c}\text { Registro } \\
\text { do } \\
\text { Animal }\end{array}$ & Espécie & Hemoscopia & "Imprint" & $\begin{array}{c}\text { Cultura } \\
\text { de } \\
\text { órgãos }\end{array}$ & Hemocultura & $\begin{array}{c}\text { Xeno- } \\
\text { diagnóstico }\end{array}$ & Flagelados \\
\hline 12 & Proechimys iheringi & + & Neg & Neg & $\mathrm{Neg}$ & Neg & Sd \\
\hline 13 & Proechimys iheringi & Neg & Neg & Neg & $\mathrm{Neg}$ & + & T. cruzi (?) \\
\hline 112 & Proechimys iheringi & Neg & Neg & Neg & $\mathrm{Neg}$ & $+*$ & T. cruzi \\
\hline 114 & Proechimys iheringi & + & Neg & $\mathrm{Neg}$ & Neg & $+*$ & T. cruzi \\
\hline 118 & Roedor & + & Neg & Neg & + & Neg & Herpetosoma (?) \\
\hline 120 & Proechimys iheringi & + & $\mathrm{Neg}$ & Neg & Neg & $\mathrm{Neg}$ & $S d$ \\
\hline 126 & Proechimys iheringi & Neg & $\mathrm{Neg}$ & + & Neg & Neg & Leishmania \\
\hline 134 & Proechimys iheringi & + & $\mathrm{Neg}$ & Neg & + & $\mathrm{Neg}$ & Herpetosoma (?) \\
\hline 142 & Didelphis marsupialis & Neg & Neg & Neg & Neg & $+*$ & T. cruzi \\
\hline 154 & Philander opossum & Neg & Neg & Neg & + & $\mathrm{Neg}$ & Sd \\
\hline 170 & Philander opossum & $\mathrm{Neg}$ & Neg & Neg & Neg & $+*$ & T. cruzi \\
\hline 174 & Philander opossum & Neg & Neg & $+*$ & $+*$ & Neg & T. cruzi \\
\hline 176 & Philander opossum & $\mathrm{Neg}$ & Neg & $+*$ & $\mathrm{Neg}$ & $+*$ & T. cruzi \\
\hline
\end{tabular}

Neg = negativo, $\mathrm{Sd}=$ sem diagnóstico, " amostra isolada, (?) diagnóstico provável baseado em critérios morfológicos elou biológicos 
Tabela 5. Amostras de Trypanosoma cruzi isolados de animais silvestres capturados no Estado de São Paulo, Brasil. Designação do isolado, hospedeiro de origem, técnica de isolamento e municípios de origem.

\begin{tabular}{|c|c|c|c|}
\hline Isolado & Hospedeiro de origem & Técnica de isolamento & Municípios \\
\hline Ag5P & Didelphis albiventris & Punçăo cardíaca & Araraquara \\
\hline Ag5X & Dldelphis alblventris & Xenocultura & Araraquara \\
\hline $\operatorname{Eg} 23 X$ & Didelphis marsupialis & Xenocultura & Eldorado \\
\hline Eg23P & Dldelphis marsupialis & Punçáo cardiaca & Eldorado \\
\hline $\mathrm{Eg} 23 \mathrm{~F} / \mathrm{B}$ & Didelphis marsupialis & Aspirado flgado/baço & Eldorado \\
\hline Eg24X & Dldelphis marsupialis & Xenocultura & Eldorado \\
\hline Eg31P & Didelphis marsupialis & Punçăo cardiaca & Eldorado \\
\hline Eg32X & Didelphis marsupialis & Xenocultura & Eldorado \\
\hline $\operatorname{Ir} 12 x$ & Proechimys iheringi & Xenocultura & Ilhabela \\
\hline $\operatorname{Ir} 14 X$ & Proechimys iheringi & Xenocultura & Ilhabela \\
\hline $\lg 42 x$ & Didelphis marsupialis & Xenocultura & Ilhabela \\
\hline Ic70x & Philander opossum & Xenocultura & Ilhabela \\
\hline Ic74P & Philander opossum & Punçăo cardiaca & Ilhabela \\
\hline Ic74F/B & Philander opossum & Aspirado flgado/baço & Ilhabela \\
\hline Ic76X & Philander opossum & Xenocultura & Ilhabela \\
\hline Ic76F/B & Phllander opossum & Aspirado flgado/baço & Ilhabela \\
\hline
\end{tabular}


Tabela 6. Evolução da infecção em camundongos BALB/c normais. inoculados com $3 \times 10^{5}$ tripomastigotas metaciclicas de Trypanosoma cruzi, isolados de animais silvestres capturados no Estado de São Paulo, Brasil. Periodos prépatente e patente expressos em dias após infecção (d.p.i)

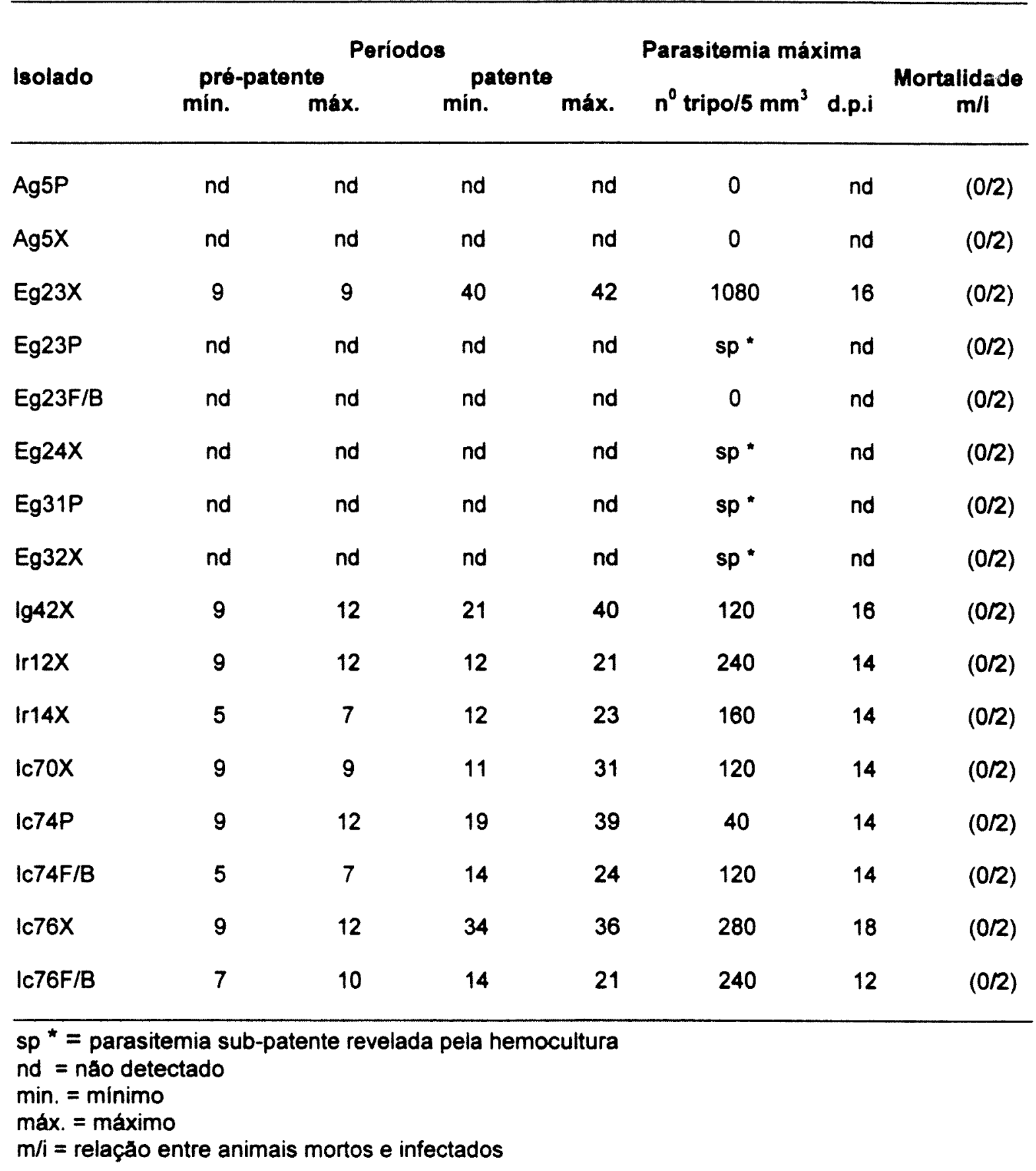


Tabela 7. Evolução da infecção em camundongos BALB/c imunodeprimidos com ciclofosfamida, inoculados com $3 \times 10^{5}$ tripomastigotas metacíclicas de Trypanosoma cruzi, isolados de animais silvestres capturados no Estado de São Paulo, Brasil. Períodos pré-patente e patente expressos em dias após infecção (d.p.i)

\begin{tabular}{|c|c|c|c|c|c|c|c|}
\hline \multirow[b]{2}{*}{ Isolado } & \multicolumn{4}{|c|}{ Periodos } & \multicolumn{2}{|c|}{ Parasitemia máxima } & \multirow[b]{2}{*}{$\begin{array}{c}\text { Mortalidade } \\
\mathrm{m} / \mathbf{i}\end{array}$} \\
\hline & $\begin{array}{l}\text { pró- } \\
\text { min. }\end{array}$ & máx. & $\begin{array}{l}\text { pa } \\
\text { min. }\end{array}$ & máx. & $\mathrm{n}^{0}$ tripo/5 $\mathrm{mm}^{3}$ & d.p.i & \\
\hline Ag5P & nd & nd & nd & nd & 0 & nd & $(0 / 2)$ \\
\hline $\operatorname{Ag} 5 \mathrm{X}$ & nd & nd & nd & nd & 0 & nd & $(0 / 2)$ \\
\hline Eg23X & 5 & 7 & 30 & 35 & 1640 & 19 & $(2 / 2)$ \\
\hline Eg23P & nd & nd & nd & nd & sp * & nd & $(0 / 2)$ \\
\hline Eg23F/B & nd & nd & nd & nd & 0 & nd & $(0 / 2)$ \\
\hline Eg24X & nd & nd & nd & nd & $s p *$ & nd & $(0 / 2)$ \\
\hline Eg31P & nd & nd & nd & nd & sp * & nd & $(1 / 2)$ \\
\hline Eg32X & nd & nd & nd & nd & $\mathbf{s p} *$ & nd & $(0 / 2)$ \\
\hline $\lg 42 x$ & 7 & 9 & 21 & 26 & 320 & 19 & $(2 / 2)$ \\
\hline $\operatorname{lr} 12 x$ & 5 & 7 & 16 & 23 & 18400 & 14 & $(2 / 2)$ \\
\hline $\operatorname{Ir} 14 X$ & 5 & 7 & 19 & 28 & 3200 & 17 & $(0 / 2)$ \\
\hline $1070 x$ & 9 & 9 & 26 & 33 & 1160 & 14 & $(2 / 2)$ \\
\hline Ic74P & 9 & 9 & 19 & 40 & 320 & 14 & $(1 / 2)$ \\
\hline IC74F/B & 5 & 7 & 19 & 30 & 1280 & 17 & $(0 / 2)$ \\
\hline Ic76x & 7 & 9 & 36 & 39 & 1760 & 13 & $(2 / 2)$ \\
\hline Ic76F/B & 7 & 7 & 33 & 42 & 1120 & 14 & $(1 / 2)$ \\
\hline \multicolumn{8}{|c|}{$\begin{array}{l}\text { sp }^{*}=\text { parasitemia sub-patente revelada pela hemocultura } \\
\text { nd = năo detectado } \\
\text { min. = mínimo } \\
\text { máx. = máximo } \\
\text { m/i = relaçăo entre animais mortos e infectados }\end{array}$} \\
\hline
\end{tabular}


Tabela 8. Evolução da infecção em ratos Wistar normais, inoculados com $3 \times 10^{5}$ tripomastigotas metaciclicas de Trypanosoma cruzi, isolados de animais silvestres capturados no Estado de São Paulo, Brasil. Periodos pré-patente e patente expressos em dias após infecção (d.p.i)

\begin{tabular}{|c|c|c|c|c|c|c|c|}
\hline \multirow[b]{2}{*}{ Isolado } & \multicolumn{4}{|c|}{ Períodos } & \multicolumn{2}{|c|}{ Parasitemia máxima } & \multirow[b]{2}{*}{$\begin{array}{c}\text { Mortalidade } \\
\mathrm{m} / \mathrm{i}\end{array}$} \\
\hline & $\begin{array}{l}\text { pré } \\
\text { min. }\end{array}$ & $\begin{array}{l}\text { nte } \\
\text { máx. }\end{array}$ & mín. & máx. & $\mathrm{n}^{0}$ tripo/5 $\mathrm{mm}^{3}$ & d.p.i & \\
\hline Ag5P & nd & nd & nd & nd & sp * & nd & $(0 / 2)$ \\
\hline $\operatorname{Ag} 5 X$ & nd & nd & nd & nd & sp * & nd & $(0 / 2)$ \\
\hline Eg23X & 7 & 9 & 14 & 21 & 1680 & 21 & $(0 / 2)$ \\
\hline Eg23P & 14 & 19 & 12 & 21 & 320 & 28 & $(0 / 2)$ \\
\hline $\mathrm{Eg} 23 \mathrm{~F} / \mathrm{B}$ & nd & nd & nd & nd & 40 & 35 & $(0 / 2)$ \\
\hline Eg24X & 9 & 9 & 21 & 26 & 840 & 26 & $(0 / 2)$ \\
\hline Eg31P & 7 & 10 & 16 & 17 & 400 & 19 & $(0 / 2)$ \\
\hline Eg32X & 19 & 19 & 14 & 23 & 40 & 31 & $(0 / 2)$ \\
\hline $\lg 42 x$ & nd & nd & nd & nd & 40 & 22 & $(0 / 2)$ \\
\hline $\operatorname{Ir} 12 X$ & 9 & 16 & 7 & 7 & 40 & 16 & $(0 / 2)$ \\
\hline $\operatorname{Ir} 14 x$ & 10 & 12 & 7 & 7 & 80 & 14 & $(0 / 2)$ \\
\hline Ic70X & 14 & 16 & 5 & 10 & 40 & 16 & $(0 / 2)$ \\
\hline Ic74P & 14 & 14 & 14 & 26 & 40 & 14 & $(0 / 2)$ \\
\hline Ic74F/B & nd & nd & nd & nd & 40 & 12 & $(0 / 2)$ \\
\hline $1076 x$ & 13 & 15 & 5 & 12 & 120 & 18 & $(0 / 2)$ \\
\hline Ic76F/B & 12 & 12 & 9 & 12 & 160 & 17 & $(0 / 2)$ \\
\hline
\end{tabular}

$\mathrm{sp}^{*}=$ parasitemia sub-patente revelada pelo microhematocrito

nd = náo detectado

min. $=$ mínimo

máx. $=$ máximo

$\mathrm{m} / \mathrm{i}=$ relaçăo entre animais mortos e infectados 
Tabela 9. Evolução da infecção em ratos Wistar imunodeprimidos com ciclofosfamida, inoculados com $3 \times 10^{5}$ tripomastigotas metacíclicas de Trypanosoma cruzi, isolados de animais silvestres capturados no Estado de São Paulo, Brasil. Períodos pré-patente e patente expressos em dias após infeç̧ão (d.p.i)

\begin{tabular}{|c|c|c|c|c|c|c|c|}
\hline \multirow[b]{2}{*}{ lsolado } & \multicolumn{4}{|c|}{ Períodos } & \multicolumn{2}{|c|}{ Parasitemia máxima } & \multirow[b]{2}{*}{$\underset{\mathrm{m} / \mathrm{i}}{\text { Mortalidade }}$} \\
\hline & $\begin{array}{c}\text { pré. } \\
\text { min. }\end{array}$ & máx. & $\begin{array}{l}\text { pe } \\
\text { min. }\end{array}$ & máx. & $\mathrm{n}^{0}$ tripo/5 $\mathrm{mm}^{3}$ & d.p.i & \\
\hline Ag5P & nd & nd & nd & nd & sp * & nd & $(0 / 2)$ \\
\hline $\operatorname{Ag} 5 \mathrm{X}$ & nd & nd & nd & nd & $s p *$ & nd & $(0 / 2)$ \\
\hline Eg23X & 7 & 9 & 26 & 33 & 2440 & 21 & $(0 / 2)$ \\
\hline Eg23P & 13 & 13 & 36 & 49 & 1240 & 24 & $(0 / 2)$ \\
\hline $\mathrm{Eg} 23 \mathrm{~F} / \mathrm{B}$ & 13 & 17 & 20 & 32 & 40 & 26 & $(0 / 2)$ \\
\hline Eg24X & 7 & 9 & 38 & 45 & 1200 & 26 & $(0 / 2)$ \\
\hline Eg31P & 7 & 10 & 25 & 33 & 1480 & 26 & $(0 / 2)$ \\
\hline $\operatorname{Eg} 32 X$ & 13 & 17 & 11 & 29 & 280 & 21 & $(0 / 2)$ \\
\hline $\lg 42 x$ & nd & nd & nd & nd & 40 & 19 & $(0 / 2)$ \\
\hline $\operatorname{Ir} 12 X$ & 12 & 14 & 14 & 21 & 1640 & 19 & $(0 / 2)$ \\
\hline $\operatorname{Ir} 14 X$ & 10 & 10 & 18 & 37 & 1800 & 19 & $(0 / 2)$ \\
\hline Ic70X & 14 & 16 & 26 & 35 & 2880 & 23 & $(0 / 2)$ \\
\hline Ic74P & 14 & 16 & 7 & 16 & 80 & 21 & $(1 / 2)$ \\
\hline Ic74F/B & 10 & 13 & 23 & 25 & 2360 & 26 & $(0 / 2)$ \\
\hline Ic76X & 12 & 12 & 30 & 38 & 1040 & 26 & $(0 / 2)$ \\
\hline Ic76F/B & 12 & 14 & 26 & 28 & 1640 & 26 & $(0 / 2)$ \\
\hline
\end{tabular}

$\mathbf{s p}^{*}=$ parasitemia sub-patente revelada pelo microhematócrito

nd = náo detectado

min. $=$ minimo

máx. = máximo

$\mathrm{m} / \mathrm{i}=$ relação entre animais mortos e infectados 
Tabela 10. Tipos morfológicos de tripomastigotas sangüíneos, observados na infecção experimental das amostras de Trypanosoma cruzi, isolados de animais silvestres capturados no Estado de São Paulo.

\begin{tabular}{|c|c|c|}
\hline Isolado & Animal de experimentação & Tripomastigota sangüínea \\
\hline Ag5P & Ratos Wistar * & Larga \\
\hline $\operatorname{Ag} 5 \mathrm{X}$ & Ratos Wistar * & Larga \\
\hline Eg23X & Ratos Wistar & Delgada/ Intermediária/ Larga/ Muito Larga \\
\hline Eg23P & Ratos Wistar & Intermediária/ Larga/ Muito Larga \\
\hline $\mathrm{Eg} 23 \mathrm{~F} / \mathrm{B}$ & Ratos Wistar & Intermediária/ Larga/ Muito Larga \\
\hline Eg24X & Ratos Wistar & Intermediária/ Larga/ Muito Larga \\
\hline Eg31P & Ratos Wistar & Intermediária/ Larga/ Muito Larga \\
\hline Eg32X & Ratos Wistar & Intermediária/ Larga/ Muito Larga \\
\hline $\operatorname{Ir} 12 X$ & Camundongos BALB/c & Intermediária/ Larga \\
\hline $\operatorname{Ir} 14 X$ & Camundongos BALB/C & Intermediária/ Larga \\
\hline $\lg 42 x$ & Camundongos $\mathrm{BALB} / \mathrm{C}$ & Intermediária/ Larga \\
\hline Ic70X & Ratos Wistar & Intermediária/ Larga/ Muito Larga \\
\hline Ic74P & Camundongos BALB/C & Intermediária/ Larga \\
\hline IC74F/B & Ratos Wistar & Intermediária/ Larga \\
\hline Ic76X & Camundongos BALB/C & Intermediária/ Larga \\
\hline Ic76F/B & Camundongos BALB/c & Intermediária/ Larga \\
\hline
\end{tabular}

* parasitemia sub-patente (tripomastigotas no creme leucocitário) 
Tabela 11. Presença de amastigotas reveladas pela técnica de impressão de órgãos "imprint" do coração, medula óssea, fígado e baço, de camundongos (") ou ratos $\left(^{\star \star}\right)$, inoculados com as diferentes cepas. Dados qualitativos.

\begin{tabular}{|c|c|c|c|c|}
\hline \multirow{2}{*}{ Isolado } & \multirow{2}{*}{ Coração } & \multicolumn{2}{|c|}{ Órgãos } & \multirow[b]{2}{*}{ Baçc } \\
\hline & & Medula Ossea & Figado & \\
\hline Ag5P ** & neg & neg & neg & + \\
\hline Ag5X ** & + & neg & neg & neg \\
\hline Eg23X * & +++ & ++ & ++ & ++ \\
\hline Eg23P ** & ++ & + & + & neg \\
\hline $\mathrm{Eg} 23 \mathrm{~F} / \mathrm{B}$ ** & + & neg & neg & neg \\
\hline Eg24X ** & + & neg & neg & neg \\
\hline Eg31P ** & +++ & + & + & + \\
\hline $\operatorname{Eg} 32 X$ ** & + & + & neg & + \\
\hline $\lg 42 x$ * & + & + & neg & neg \\
\hline $\operatorname{Ir} 12 x$ * & + & + & + & + \\
\hline $\operatorname{lr} 14 X$ * & + & + & +++ & ++ \\
\hline Ic70X * & + & ++ & +++ & ++ \\
\hline $1674 \mathrm{P}$ * & + & + & neg & neg \\
\hline Ic74F/B * & + & neg & + & neg \\
\hline Ic76x * & + & + & ++ & + \\
\hline Ic $76 F / B^{*}$ & + & + & + & neg \\
\hline
\end{tabular}

parasitismo: + baixo, ++ moderado, +++ intenso neg $=$ negativo 
Tabela 12. Desenvolvimento das diferentes amostras de Trypanosoma cruzi. isoladas de animais silvestres, em meio LIT. Dados quantitativos sobre a metaciclogênese em função do tempo de cultivo.

\begin{tabular}{|c|c|c|c|c|c|}
\hline \multirow[b]{2}{*}{ Isolado } & \multicolumn{5}{|c|}{ Tempo de cultivo em dias } \\
\hline & 4 & 7 & 14 & 21 & 28 \\
\hline Ag5P & sm & + & +++ & ++ & $\mathrm{nr}$ \\
\hline $\operatorname{Ag} 5 \mathrm{X}$ & + & ++ & +++ & $\mathrm{nr}$ & +++ \\
\hline Eg23X & $\mathrm{sm}$ & + & + & + & $\mathrm{nr}$ \\
\hline Eg23P & ++ & ++ & +++ & $\mathrm{nr}$ & $\mathrm{nr}$ \\
\hline $\mathrm{Eg} 23 \mathrm{~F} / \mathrm{B}$ & + & ++ & ++ & +++ & $\mathrm{nr}$ \\
\hline Eg24X & + & ++ & +++ & +++ & $\mathrm{nr}$ \\
\hline Eg31P & ++ & ++ & +++ & $\mathrm{nr}$ & $\mathrm{nr}$ \\
\hline Eg32X & + & ++ & +++ & +++ & +++ \\
\hline $\lg 42 x$ & sm & + & + & + & + \\
\hline $\operatorname{Ir} 12 X$ & sm & sm & + & + & $\mathrm{nr}$ \\
\hline $\operatorname{Ir} 14 X$ & sm & + & ++ & ++ & +++ \\
\hline Ic70X & $\mathrm{sm}$ & + & + & ++ & ++ \\
\hline IC74P & $\mathrm{sm}$ & $\mathrm{sm}$ & + & ++ & $\mathrm{nr}$ \\
\hline Ic74F/B & + & + & ++ & ++ & +++ \\
\hline Ic76x & + & + & ++ & $\mathrm{nr}$ & +++ \\
\hline Ic76F/B & + & + & ++ & ++ & +++ \\
\hline
\end{tabular}

metaciclogéneses: + baixa; ++ moderada; +++ intensa $\mathrm{sm}=$ sem tripomastigota metaciclico $\mathrm{nr}=$ năo realizado 
Tabela 13. Resultados do xenodiagnóstico, aplicado em animais de experimentação, infectados com Trypanosoma cruzi, isolados de animais silvestres capturados no Estado de São Paulo, Brasil. Dados expressos em número de ninfas positivas (NP) em relação ao número de ninfas aplicadas (NA) por espécies de triatomineo e respectivo percentual de positividade (\%).

\begin{tabular}{|c|c|c|c|c|c|c|c|c|}
\hline \multirow{2}{*}{$\begin{array}{l}\text { lsolado } \\
\text { Ag5P }\end{array}$} & \multicolumn{2}{|c|}{$\begin{array}{l}\text { T. Infestans } \\
\text { NP/NA (\%) }\end{array}$} & \multicolumn{2}{|c|}{$\begin{array}{l}\text { R. neglectus } \\
\text { NP/NA (\%) }\end{array}$} & \multicolumn{2}{|c|}{$\begin{array}{l}\text { P. megistus } \\
\text { NP/NA } \quad(\%)\end{array}$} & \multicolumn{2}{|c|}{$\begin{array}{c}\text { Total } \\
\text { NP/NA (\%) }\end{array}$} \\
\hline & $6 / 8$ & $(75,0)$ & $6 / 8$ & $(75,0)$ & $3 / 6$ & $(50,0)$ & $15 / 22$ & $(68,2)$ \\
\hline $\operatorname{Ag} 5 X$ & $4 / 8$ & $(50,0)$ & $3 / 8$ & $(37,5)$ & $2 / 4$ & $(50,0)$ & $9 / 20$ & $(45,0)$ \\
\hline $\operatorname{Eg} 23 x$ & $2 / 6$ & $(33,3)$ & $2 / 6$ & $(33,3)$ & $2 / 6$ & $(33,3)$ & $6 / 18$ & $(33,3)$ \\
\hline Eg23P & $2 / 3$ & $(66,6)$ & $1 / 3$ & $(33,3)$ & $3 / 3($ & $(100,0)$ & $6 / 9$ & $(66,6)$ \\
\hline $\mathrm{Eg} 23 \mathrm{~F} / \mathrm{B}$ & $1 / 6$ & $(16,6)$ & $3 / 6$ & $(50,0)$ & $2 / 6$ & $(33,3)$ & $6 / 18$ & $(33,3)$ \\
\hline Eg24X & $2 / 6$ & $(33,3)$ & $3 / 6$ & $(50,0)$ & $2 / 6$ & $(33,3)$ & $7 / 18$ & $(38,9)$ \\
\hline Eg31P & $1 / 3$ & $(33,3)$ & $3 / 31$ & $(100,0)$ & $2 / 3$ & $(66,6)$ & $6 / 9$ & $(66,6)$ \\
\hline Eg32X & $1 / 3$ & $(33,3)$ & $2 / 3$ & $(66,6)$ & $2 / 3$ & $(66,6)$ & $5 / 9$ & $(55,5)$ \\
\hline $\lg 42 x$ & $1 / 3$ & $(33,3)$ & $2 / 3$ & $(66,6)$ & $1 / 3$ & $(33,3)$ & $4 / 9$ & $(44,4)$ \\
\hline $\operatorname{Ir} 12 X$ & $2 / 3$ & $(66,6)$ & $1 / 3$ & $(33,3)$ & $2 / 3$ & $(66,6)$ & $5 / 9$ & $(55,5)$ \\
\hline $\operatorname{Ir} 14 X$ & $4 / 6$ & $(66,6)$ & $2 / 6$ & $(33,3)$ & $3 / 6$ & $(50,0)$ & $9 / 18$ & $(50,0)$ \\
\hline Ic70X & $4 / 6$ & $(66,6)$ & $1 / 6$ & $(16,6)$ & $3 / 6$ & $(50,0)$ & $8 / 18$ & $(44,4)$ \\
\hline Ic74P & $2 / 3$ & $(66,6)$ & $1 / 3$ & $(33,3)$ & $2 / 3$ & $(66,6)$ & $5 / 9$ & $(55,5)$ \\
\hline Ic74F/B & $1 / 3$ & $(33,3)$ & $3 / 3$ & $(100,0)$ & $3 / 3$ & $(100,0)$ & $7 / 9$ & $(77,7)$ \\
\hline Ic76x & $2 / 3$ & $(66,6)$ & $2 / 3$ & $(66,6)$ & $1 / 3$ & $(33,3)$ & $5 / 9$ & $(55,5)$ \\
\hline Ic76F/B & $2 / 3$ & $(66,6)$ & $1 / 3$ & $(33,3)$ & $1 / 3$ & $(33,3)$ & $4 / 9$ & $(44,4)$ \\
\hline Total & $37 / 73$ & $(50,7)$ & $36 / 73$ & $(49,3)$ & $34 / 67$ & $(50,7)$ & $107 / 213$ & $(50,2)$ \\
\hline
\end{tabular}


Tabela 14. Polimorfismo genético observado entre as 16 amostras de Trypanosoma cruzi, isoladas de mamíferos silvestres capturados no Estado de São Paulo. Distribuição do número de amostras e respectivos hospedeiros, segundo os municipios de origem e os genótipos de $T$. cruzi.

\begin{tabular}{|c|c|c|c|c|}
\hline & \multicolumn{4}{|c|}{ Municípios } \\
\hline & Araraquara & Eldorado & Ilhabela & Total \\
\hline T. cruzil & 2 Didelphis & 5 Didelphis & 0 & 7 \\
\hline T. cruzi II & 0 & 1 Didelphis & 1 Dldelphis & 2 \\
\hline Năo Definido & 0 & 0 & $\begin{array}{l}2 \text { Proochimys } \\
5 \text { Philander }\end{array}$ & 7 \\
\hline Total & 2 & 6 & 8 & 16 \\
\hline
\end{tabular}


Tabela 15. Indice de similaridade entre os "clustres" de $T$. cruzi, isolados de animais silvestres, determinados pela técnica de RAPD. Os números representam os percentuais de bandas compartilhadas entre os isolados. A, B e C correspondem aos "clusters" derivados a partir do método de Parsimônia de Wagner.
A
B
C
Eg23X $\lg 42 X$
G

A

72

B

25

82

C

32

51

100

Eg23X 26

33

33

100

$\lg 42 x \quad 31$

24

31

31

100

G

29

31

54

25

23

100

\begin{abstract}
A = isolados de Proechimys e de Philander, sem genotipo definido pelo gene de miniexon, da llhabela; $\mathbf{B}=$ isolados de Dldelphis tipo T. cruzl I de Eldorado; Eg23X = isolado de Didelphis tipo $T$. cruzi II de Eldorado; $\mathbf{C}=$ isolados de Didelphis tipo $T$. cruzi I de Araraquara; Ig42X = isolado de D/delphis tipo $T$. cruzi II de llhabela e $\mathbf{G}=$ controle cepa $\mathbf{G}$.
\end{abstract}




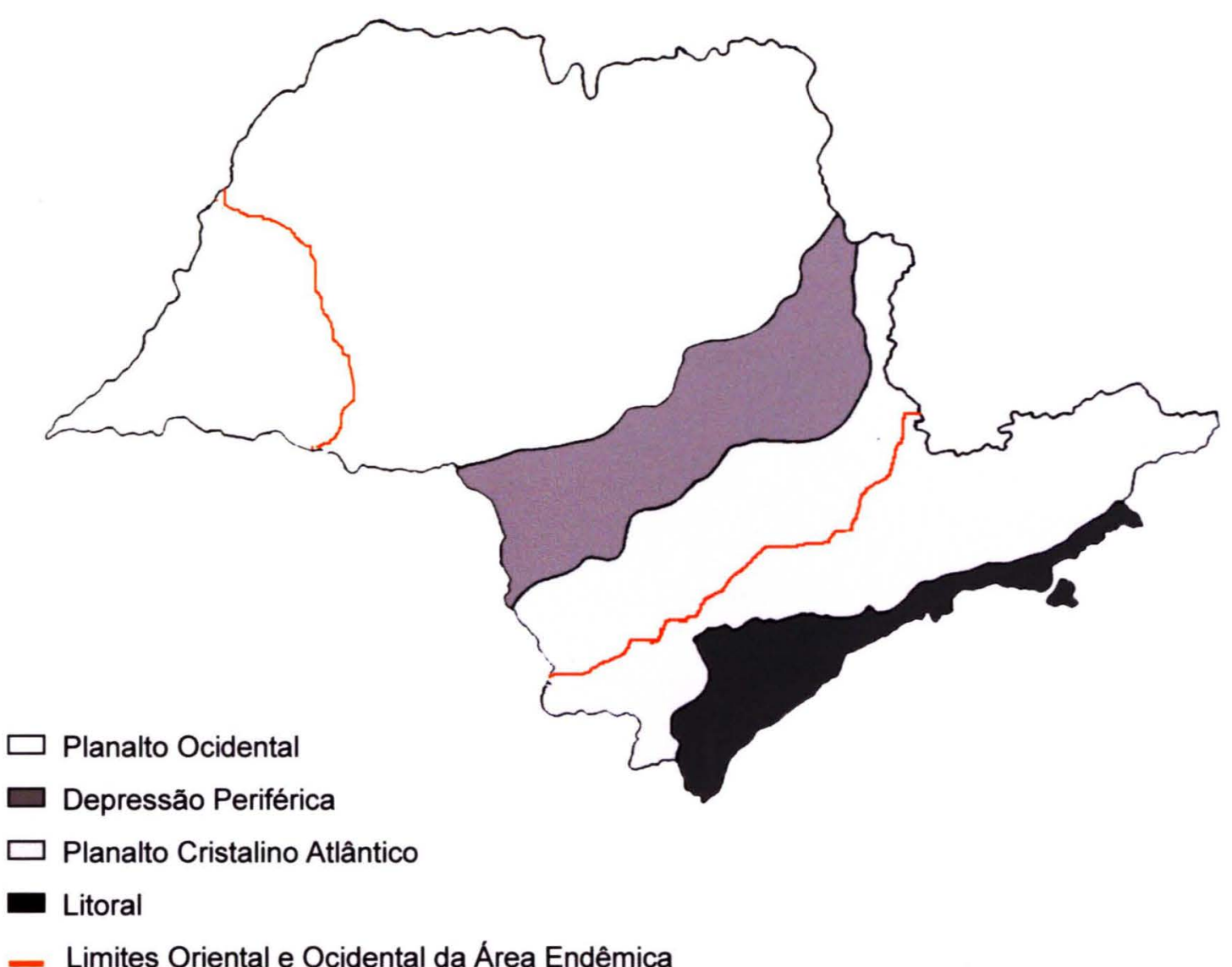

Figura 1. Mapa do Estado de São Paulo mostrando os limites oriental e ocidental que delimitam a antiga área endêmica, em relação aos domínios morfo-estruturais Reproduzido e adaptado de Silva, 1980. 


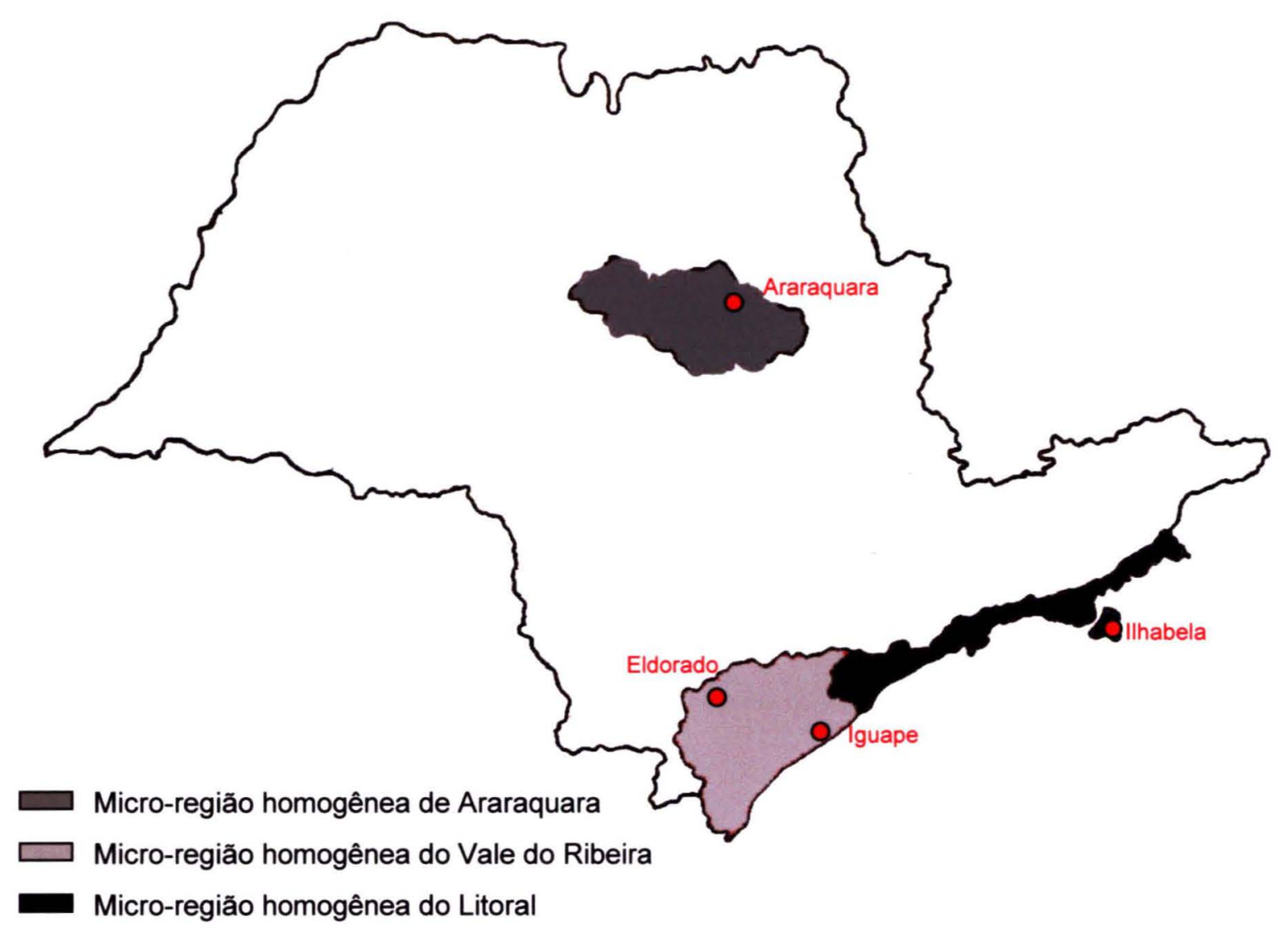

Figura 2. Mapa do Estado de São Paulo mostrando a localização das micro-regiões homogêneas e respectivos municípios estudados. 

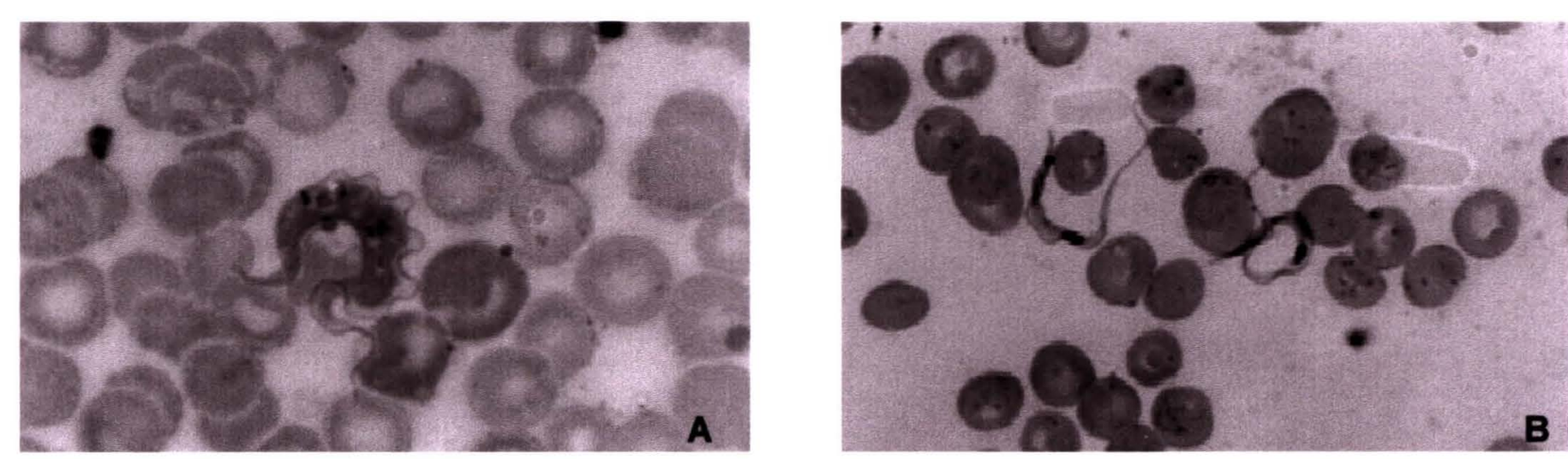

$10 \mu \mathrm{m}$

FIGURA 3. Esfregaço sangüíneo corado pelo Giemsa: A) Forma tripomastigota do subgênero Megatrypanum, provavelmente Trypanosoma freitasi, encontrado em Didelphis albiventris (A4); B) Formas tripomastigotas do subgênero. Herpetosoma encontradas em Proechimys iheringe (134). 


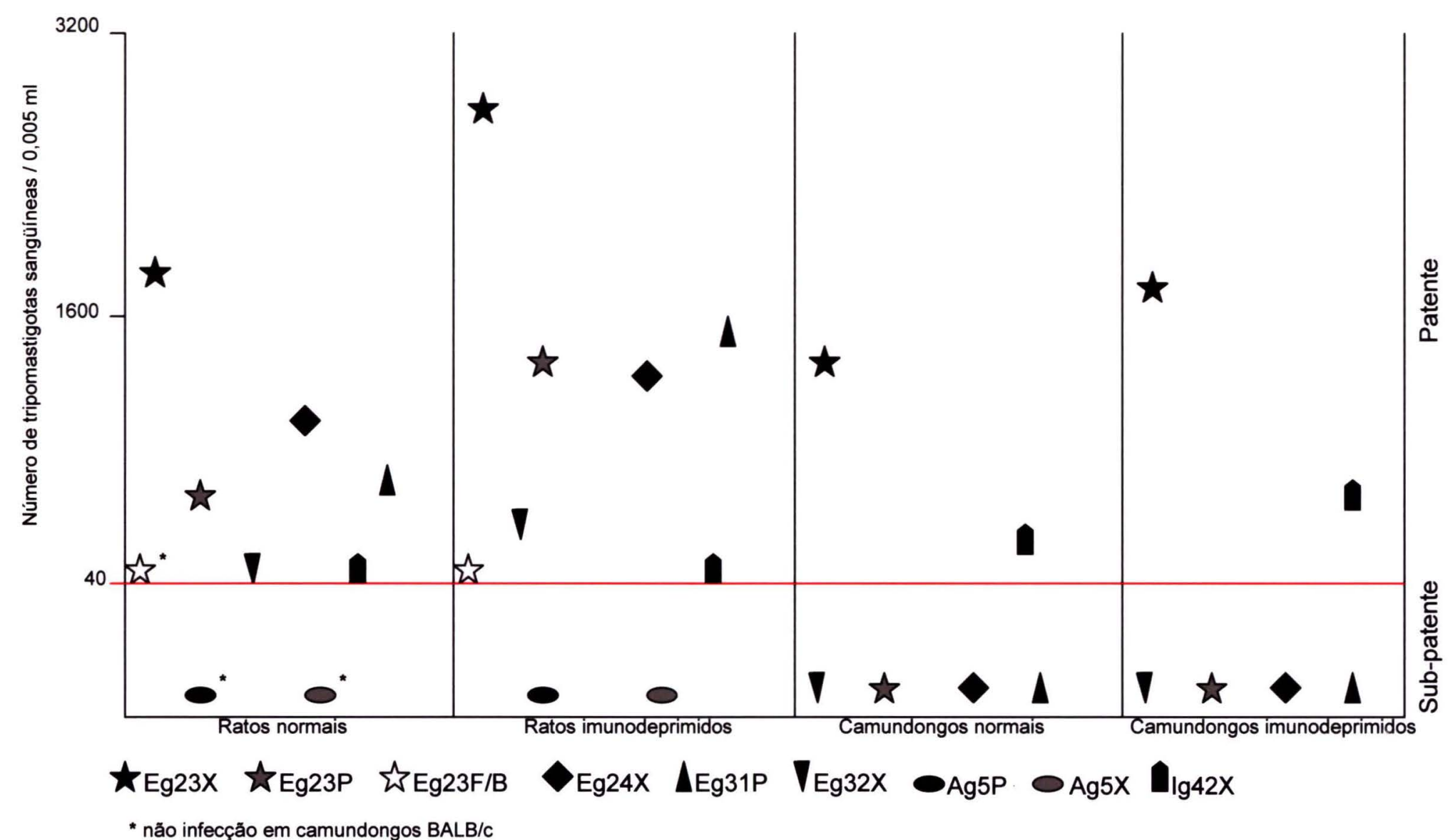

Figura 4. Níveis de parasitemias máximas observadas em ratos Wistar e camundongos BALB/c, normais e submetidos à imunodepressão pela ciclofosfamida, inoculados com $3 \times 10^{5}$ metacíclicos de Trypanosoma cruzi isolados de Didelphis marsupialis e $D$. albiventris, capturados no Estado de São Paulo. 


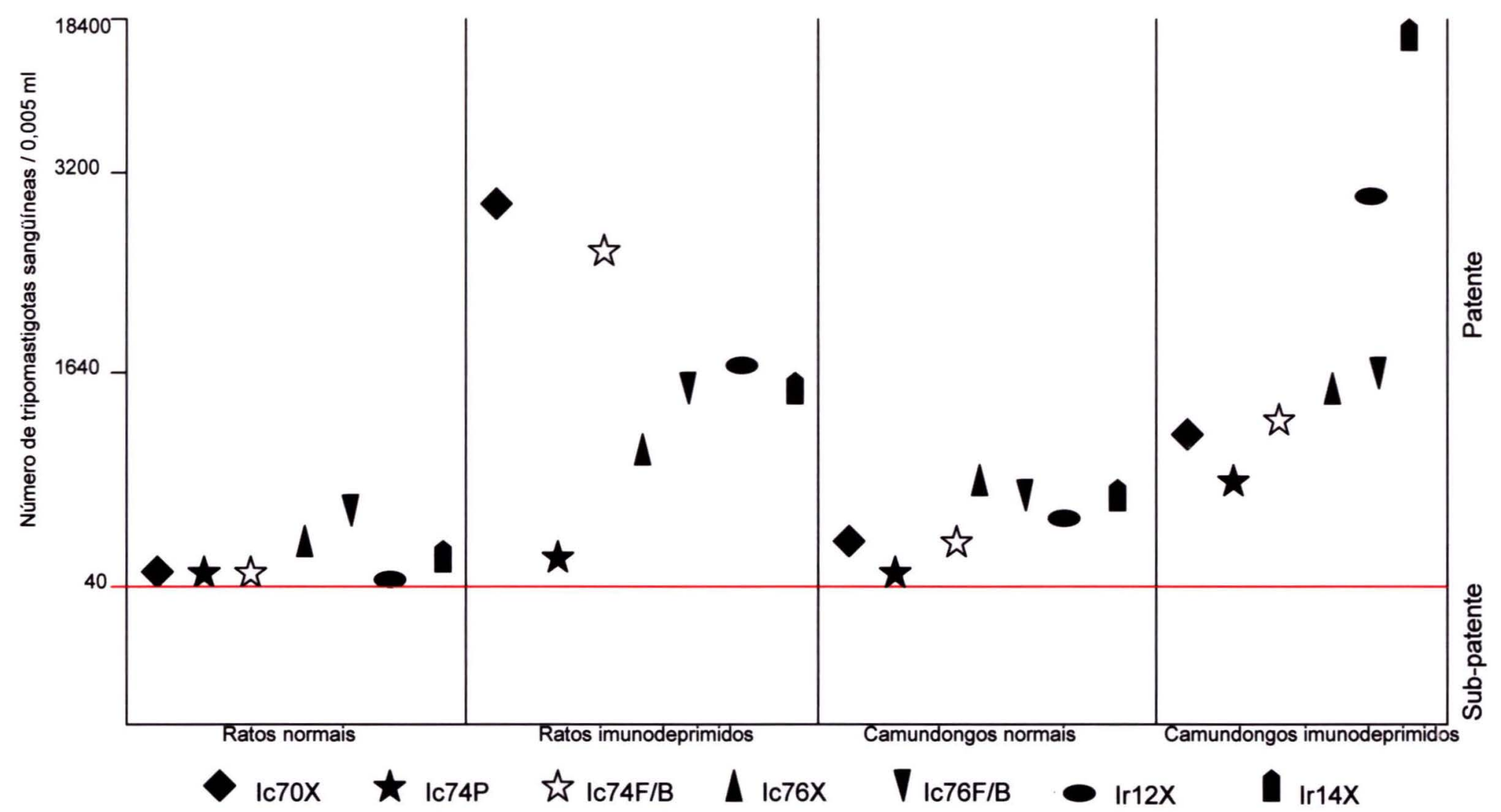

Figura 5. Níveis de parasitemias máximas observadas em ratos Wistar e camundongos BALB/c, normais e submetidos à imunodepressão pela ciclofosfamida, inoculados com $3 \times 10^{5}$ metacíclicos de Trypanosoma cruzi isolados de Philander opossum e Proechimys iheringi, capturados no Estado de São Paulo. 

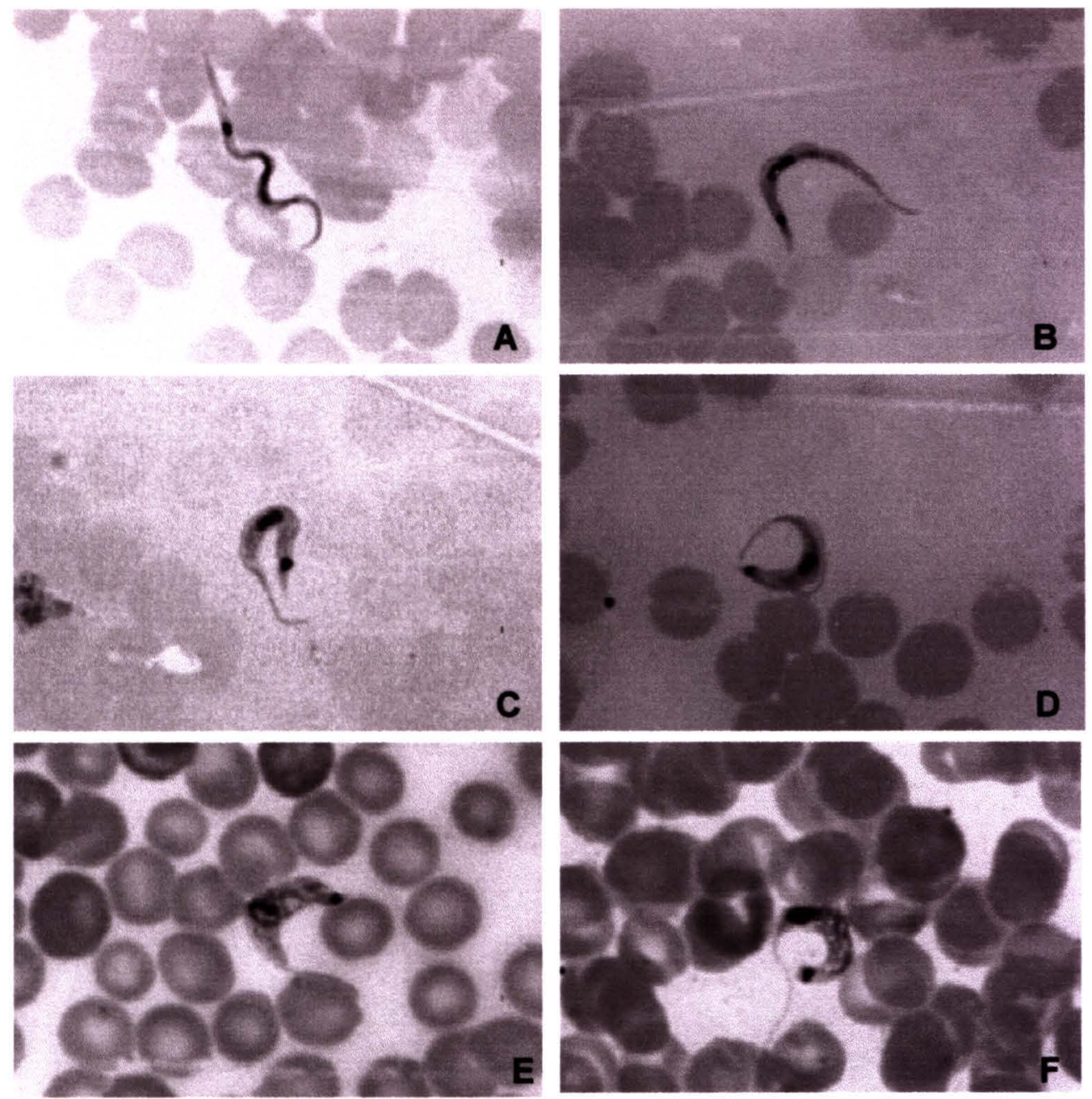

$10 \mu \mathrm{m}$

Figura 6. Esfregaço sangüíneo corado pelo Giemsa:

A) tripomastigota delgada (Eg23X);

B) e C) tripomastigotas intermediárias (Eg23X e Ic76X);

D) tripomastigota larga em forma de "C" (Eg23X) ;

E) tripomastigota muito larga (Eg31P) ;

F) tripomastigota muito larga com núcleo situado na porção anterior (Eg24X). 

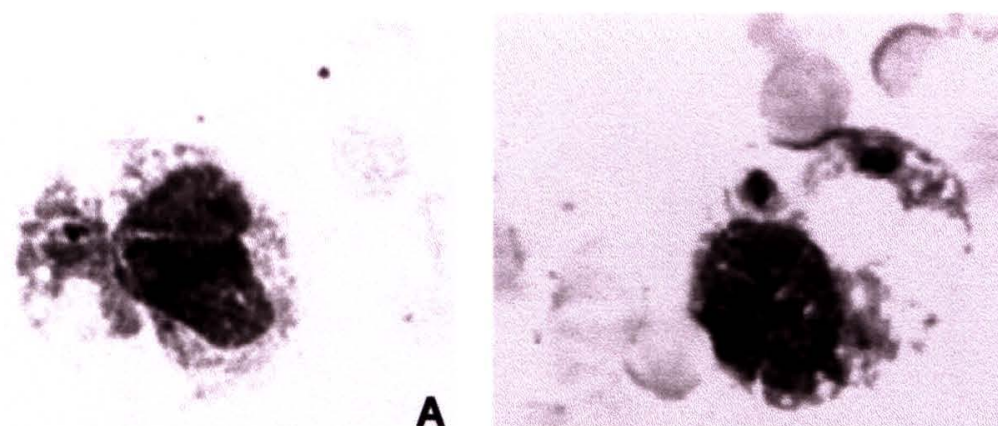

A
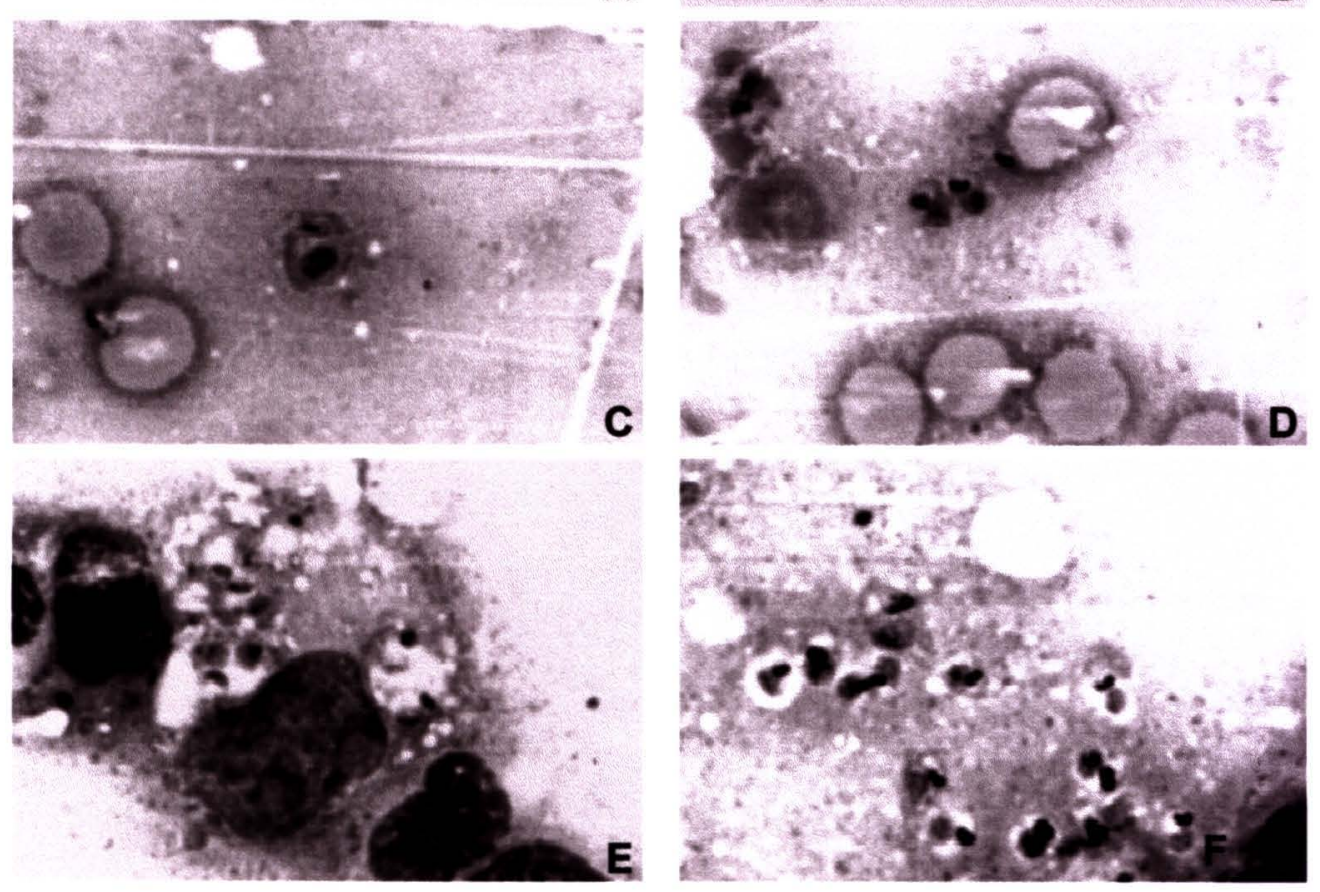

$\underline{10 \mu m}$

Figura 7. Impressão de órgãos "imprint" corado pelo Giemsa:

A) e B) formas amastigotas no citoplasma de macrófagos no coração (Eg23X);

C) amastigota isolada no coração (Eg31P);

D) amastigotas agrupadas no coração (Eg31P);

E) amastigotas intracelulares na medula óssea (Ic70X);

F) amastigotas livres na medula óssea (Ic70X). 


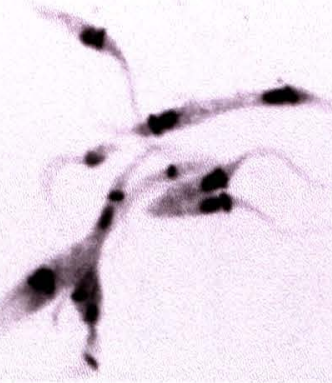

A

B
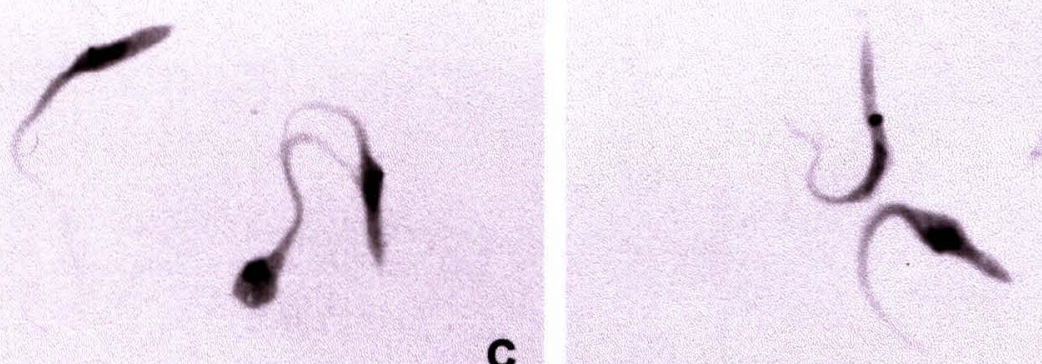

C

D

$\mathbf{E}$

$10 \mu \mathrm{m}$

FIGURA 8. Esfregaço de cultura em meio LIT corado pelo Giemsa:
A) epimastigotas de Trypanosoma cruzi em divisão (Ic74F/B);
B) epimastigotas longa e larga (Ic70X);
C) epimastigotas apresentando variabilidade de formas (Ir12X);
D) epimastigotamédia e tripomastigota metacíclica longa (Eg24X);
E) tripomastigota metacíclica longa (Eg31P);
F) tripomastigota metacíclica de tamanho médio entre duas epimastigotas ( Ir14X). 


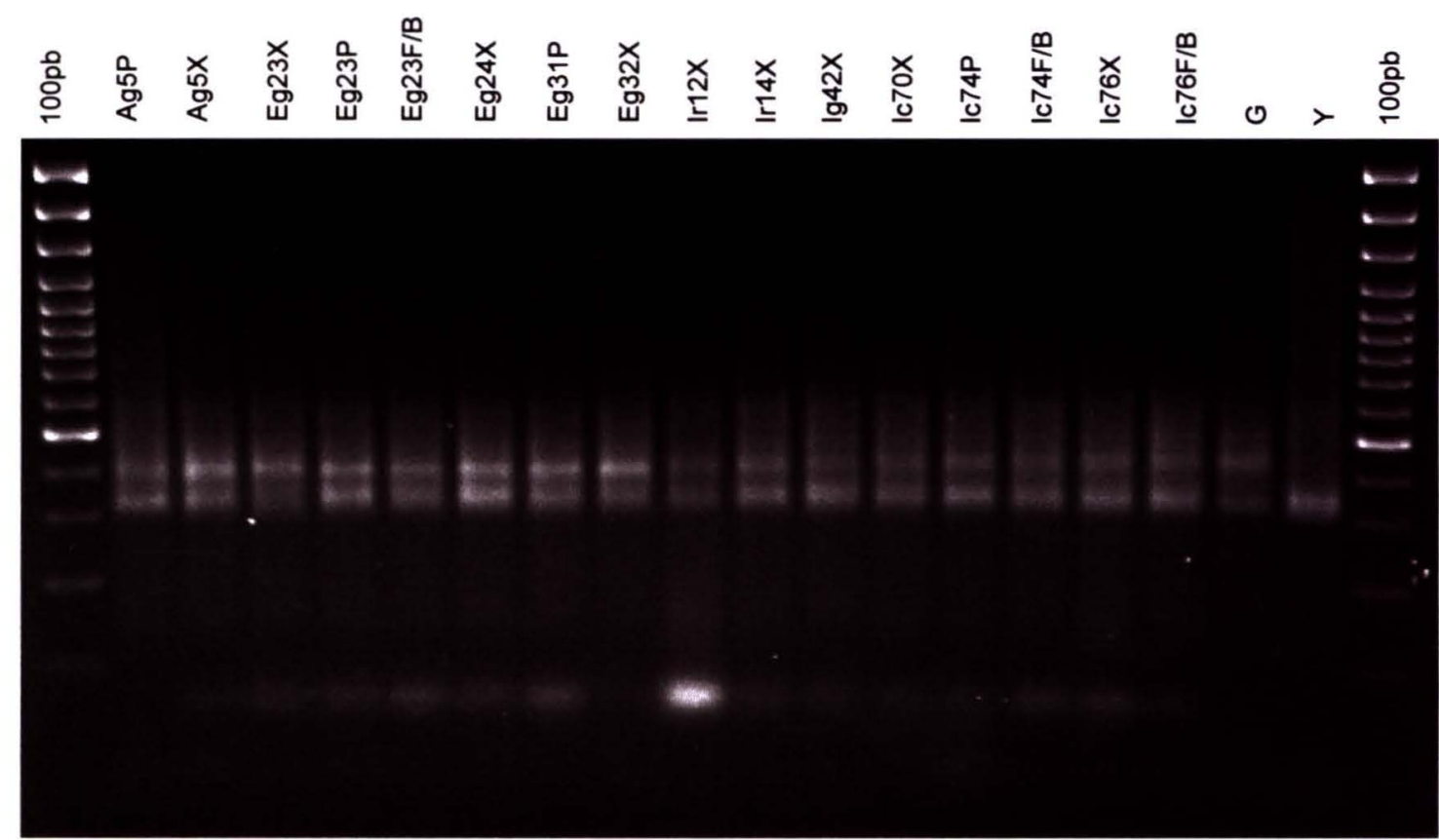

$100 \mathrm{pb}=$ marcador de peso molecular $\mathrm{pb}=$ pares de bases

G = cepa referência de $T$. cruzi isolada de Didelphis da Amazônia $\mathrm{Y}=$ cepa referência de $\boldsymbol{T}$. cruzi isolada de caso humano

Figura 9. Resultados dos produtos amplificados pela técnica de PCR, do fragmento de kDNA minicírculo, de 16 amostras de Trypanosoma cruzi isoladas de animais silvestres capturados no Estado de São Paulo, Brasil. Eletroforese em gel de agarose $2 \%$, corado com Brometo de etidium, mostrando os produtos de $330 \mathrm{pb}$, específicos para $T$. cruzi. 


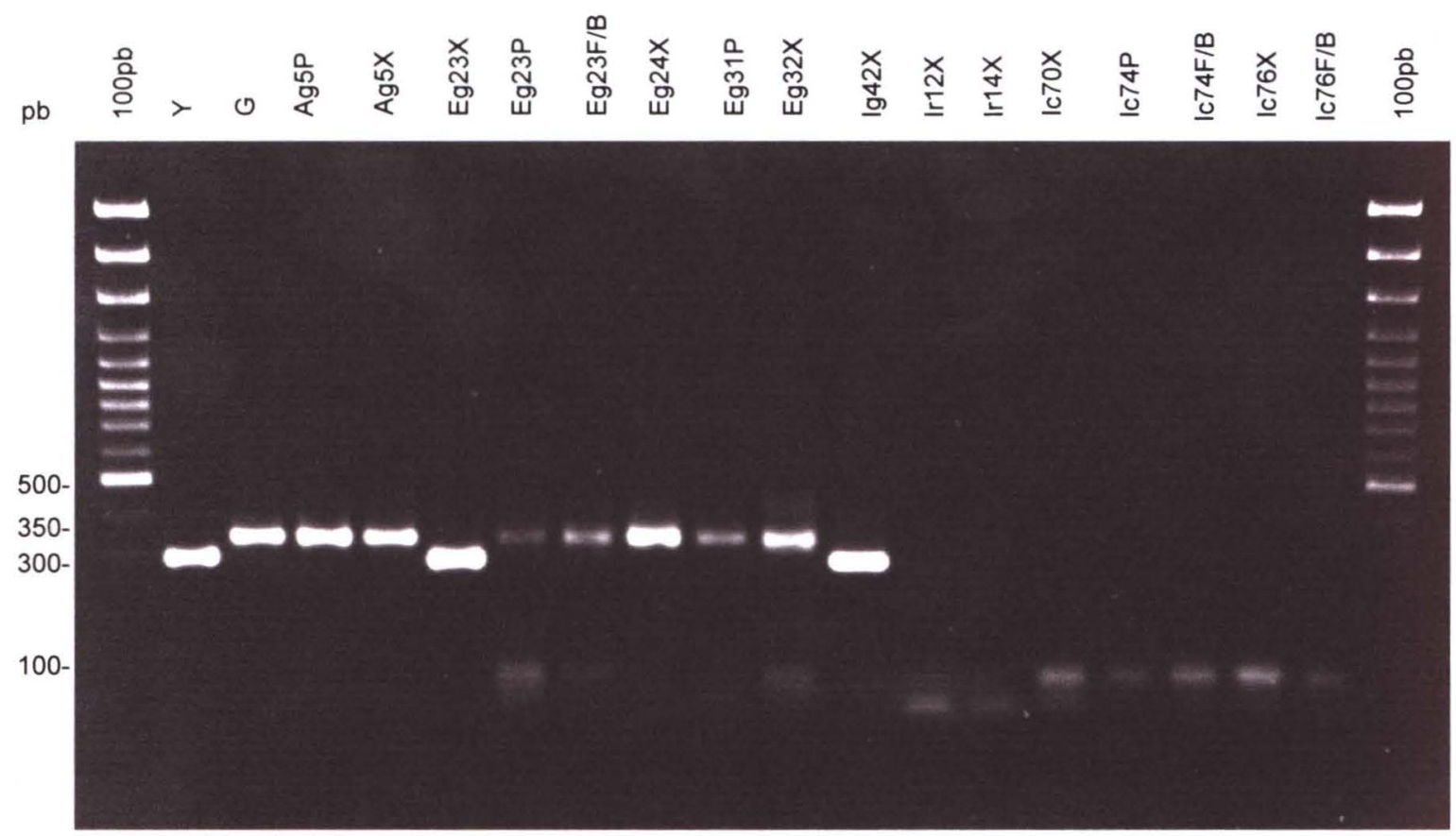

$100 \mathrm{pb}=$ marcador de peso molecular

$\mathrm{pb}=$ pares de bases

G = cepa referência de $T$. cruzi isolada de Didelphis da Amazônia

$\mathrm{Y}=$ cepa referência de $\boldsymbol{T}$. cruzi isolada de caso humano

Figura 10. Resultados dos produtos amplificados pela técnica de PCR, de um segmento da região intergênica do gene de mini-exon, de 16 amostras de Trypanosoma cruzi isoladas de animais silvestres capturados no Estado de São Paulo, Brasil. Eletroforese em gel de agarose 2\%, corado com Brometo de etidium, mostrando os produtos de $350 \mathrm{pb}$ que caracterizam $T$. cruzi l e, de $300 \mathrm{pb}$ que caracterizam $T$. cruzi II. 


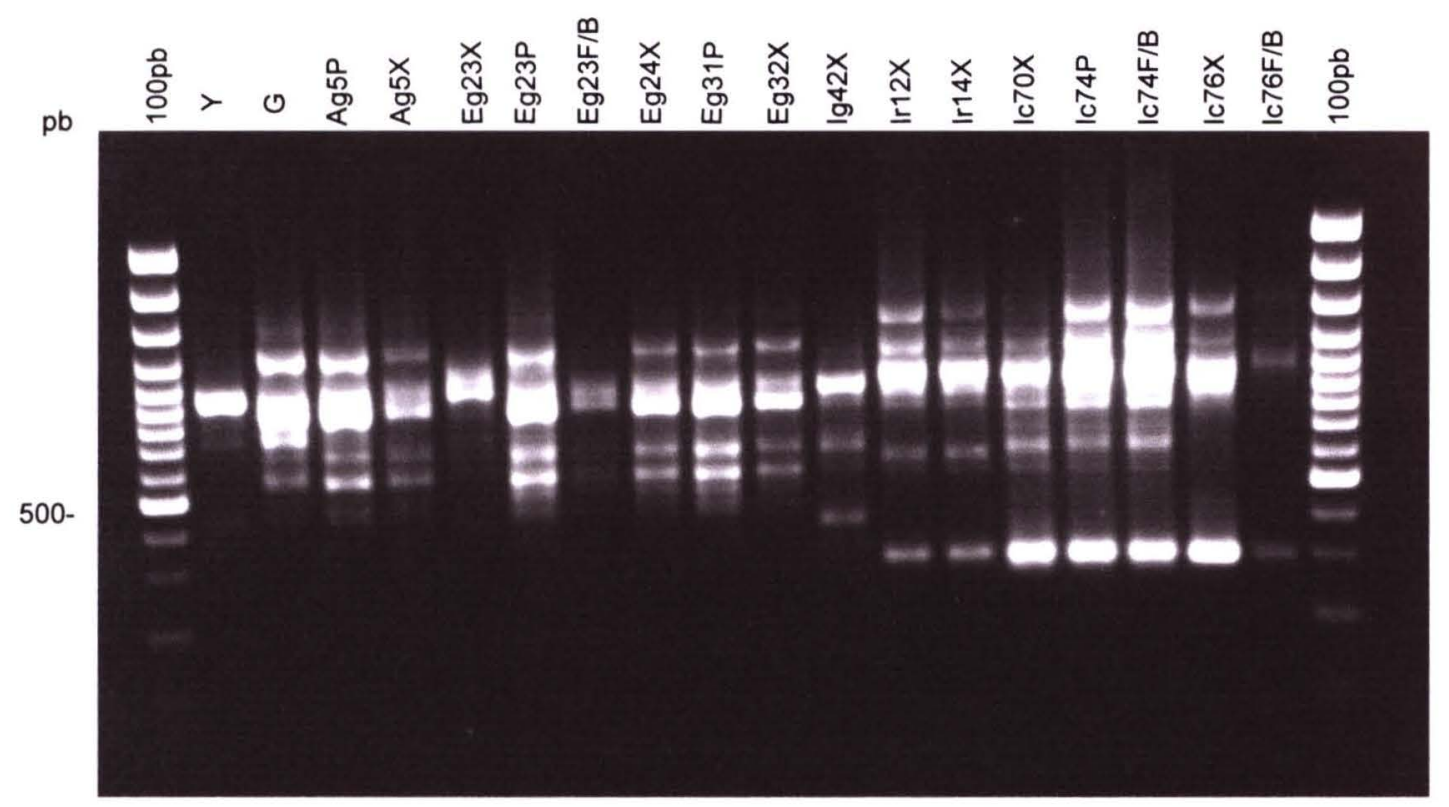

A

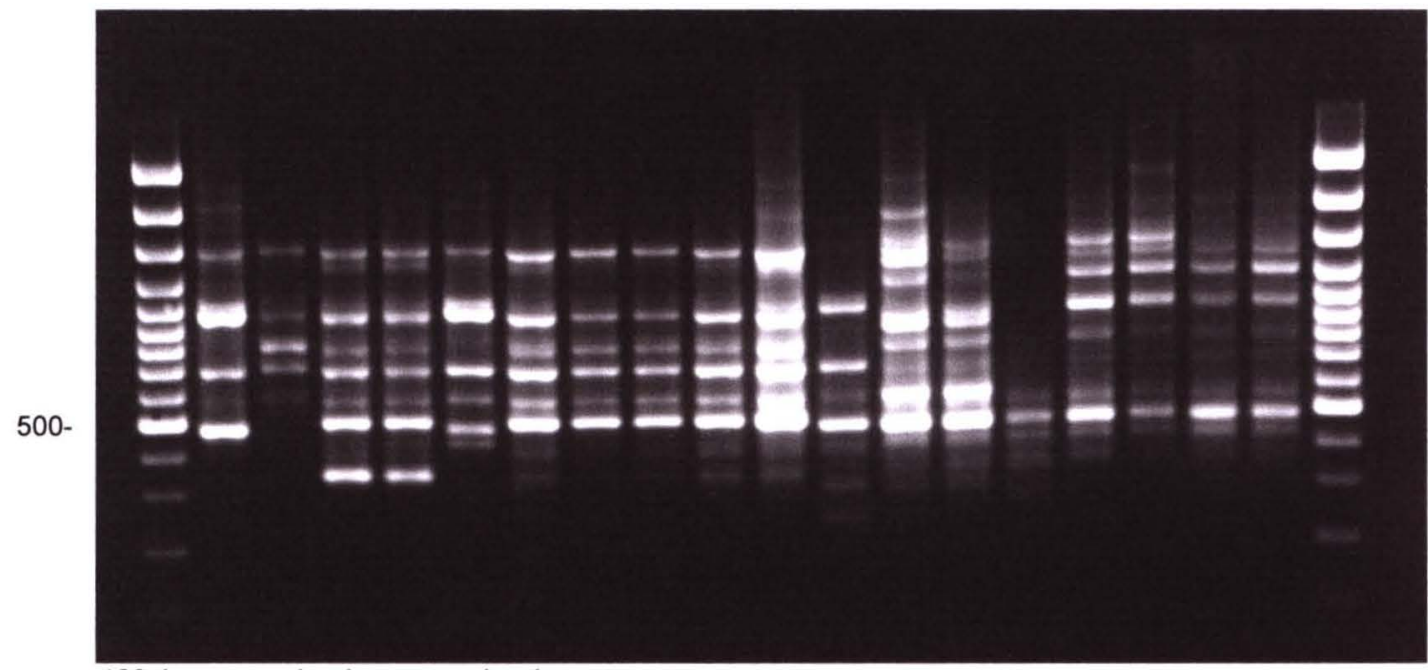

B

$100 \mathrm{pb}=$ marcador de peso molecular

$\mathrm{pb}=$ pares de bases

$\mathrm{G}$ = cepa referência de $\boldsymbol{T}$. cruzi isolada de Didelphis da Amazônia

$\mathrm{Y}=$ cepa referência de $\boldsymbol{T}$. cruzi isolada de caso humano

Figura 11. Padrões de RAPD obtidos com a amplificação de DNA de Trypanosoma cruzi isolados de animais silvestres, capturados no Estado de São Paulo, com os "primers": A) 625; B) 615. 


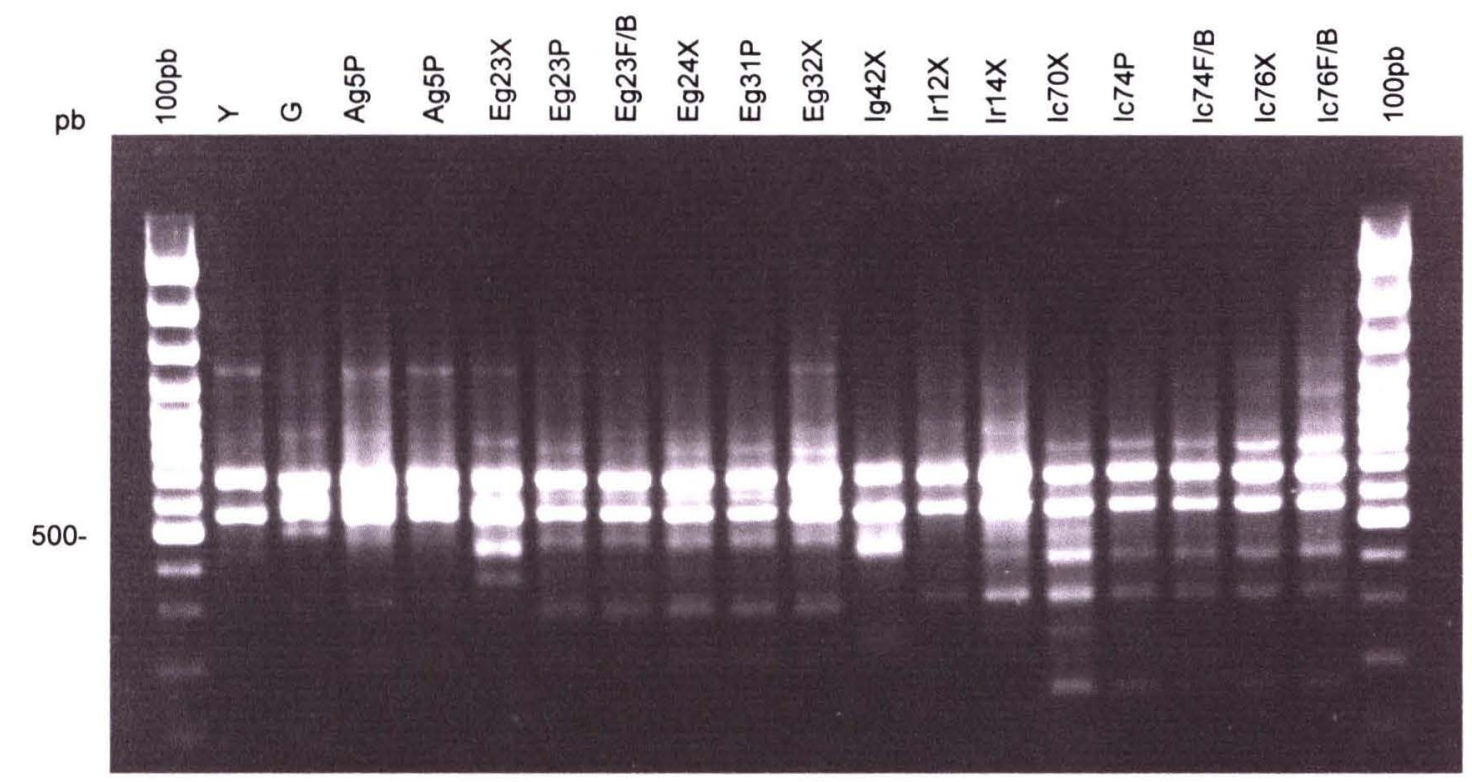

A

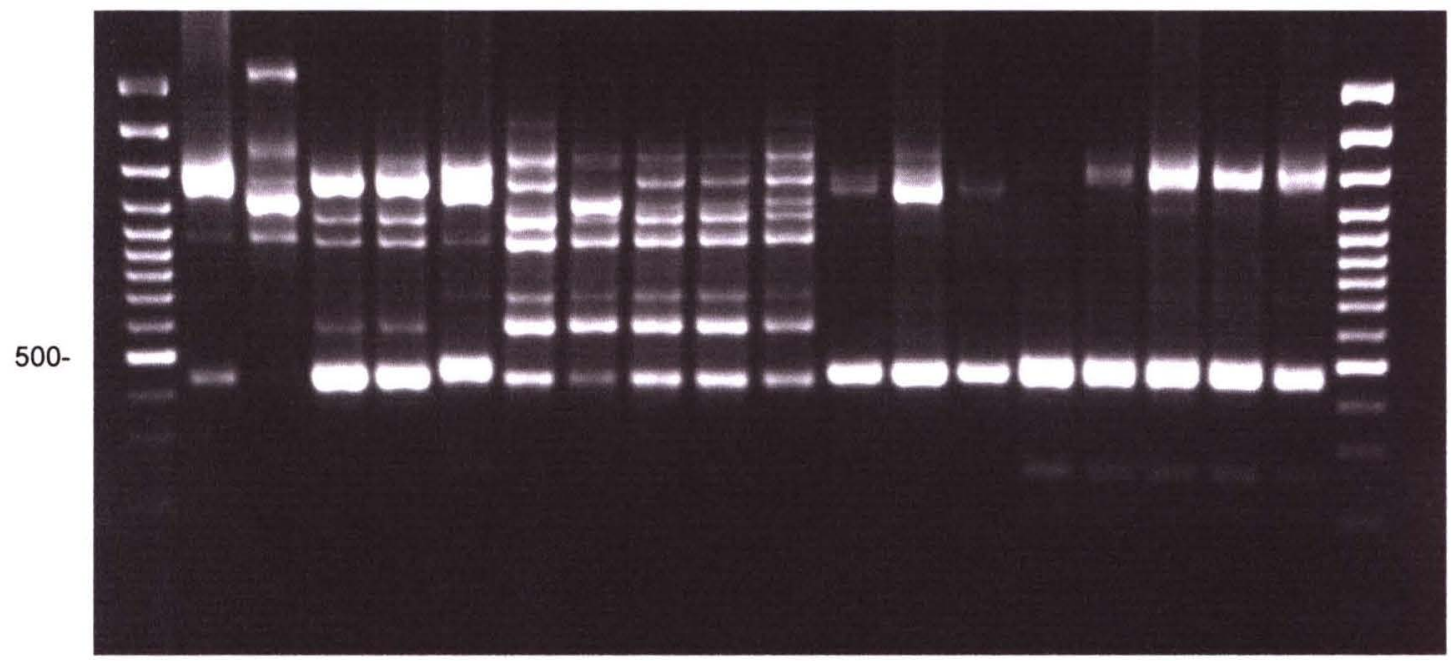

B

$100 \mathrm{pb}=$ marcador de peso molecular

$\mathrm{pb}$ - pares de bases

G = cepa referência de $T$. cruzi isolada de Didelphis da Amazônia

$\mathrm{Y}=$ cepa referência de $T$. cruzi isolada de caso humano

Figura 12. Padrões de RAPD obtidos com a amplificação de DNA de Trypanosoma cruzi isolados de animais silvestres, capturados no Estado de São Paulo, com os "primers": A) 606; B) 601. 


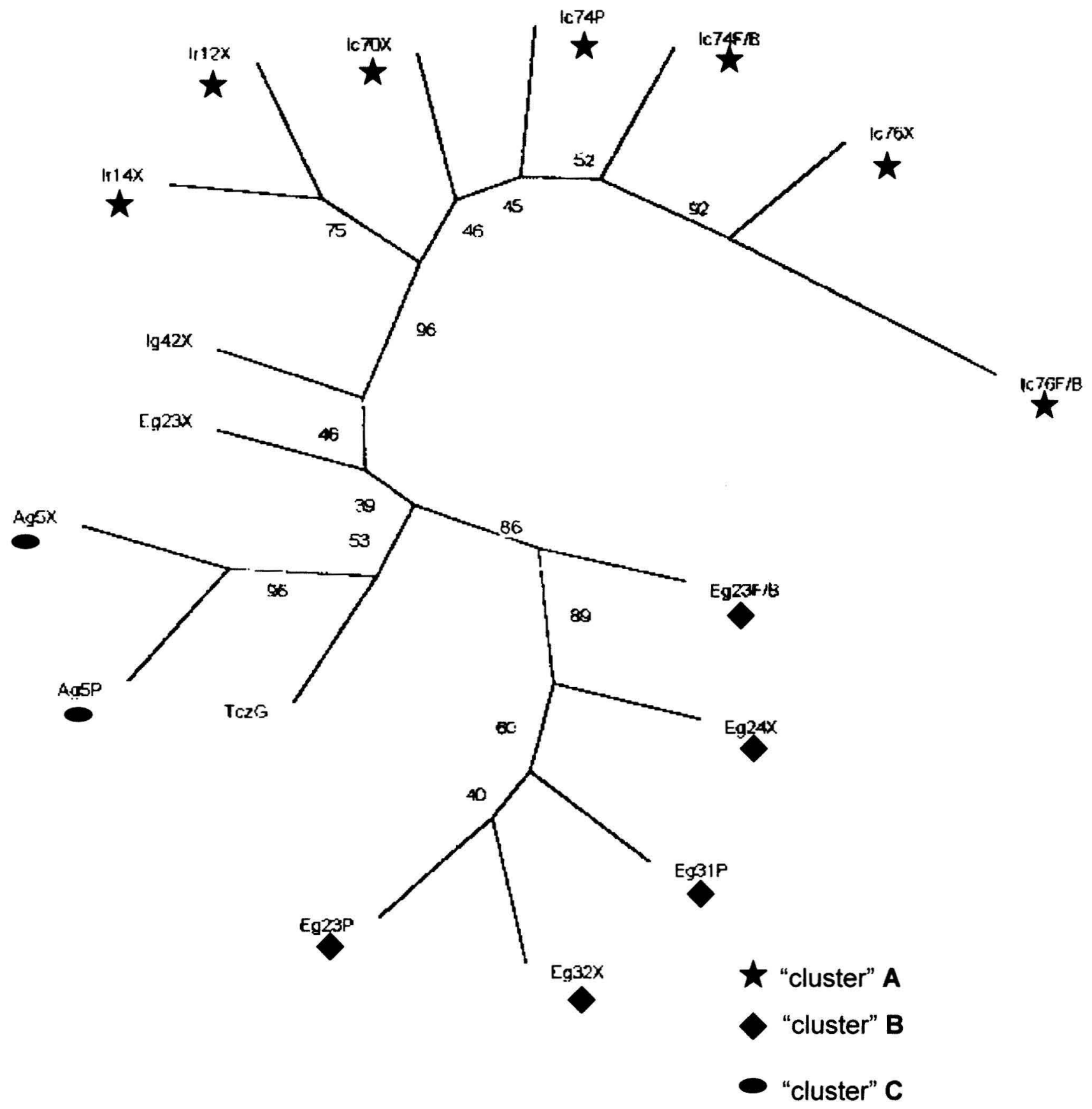

Figura 13. Dendograma das 16 amostras de Trypanosoma cruzi isoladas de animais silvestres construído a partir de padrões de RAPD com o método de Parsimônia de Wagner. Os números correspondem aos valores de "bootstrap" de 100 replicas. 


\section{DISCUSSÃO}

\section{Situação epidemiológica da doença de Chagas:}

O Estado de São Paulo e, sobretudo, a região do Planalto Ocidental Paulista, já representou uma importante área endêmica de doença de Chagas no país. Com o estabelecimento de um amplo programa de controle da transmissão da doença, iniciada na década de 50 , obteve-se a erradicação da infestação intradomiciliar do $T$. infestans e a interrupção da transmissão por triatomíneos. Por outro lado, em áreas como o Vale do Ribeira e Litoral Paulista, onde não há evidências, até o momento, de domiciliação triatomínica, os raros casos agudos registrados de infeç̧ão humana por transmissão vetorial foram vinculados ao contato do homem com o ambiente silvestre (CIARAVOLO et alii, 1997). Atualmente, nessas regiōes, têm sido desenvolvidas atividades de vigilância entomológica com ações integrando o órgão executor, a rede de atenção à saúde e a participação da população na notificação dos triatomíneos (WANDERLEY, 1994b).

Muito embora o Estado de São Paulo apresente uma situação epidemiológica que não favorece a transmissão humana da tripanossomíase americana, a constatação da presença de triatomíneos com hábitos de domiciliação, como P. megistus e $T$. sordida, em áreas submetidas ao Programa de Vigilância Epidemiológica, é de grande importância. Estudos sobre dinâmica populacional desses artrópodes no intradomicílio e peridomicilio ou pelo emprego de galinheiros experimentais, mostraram que 
essas espécies podem reinfestar áreas já controladas e manter a circulação do T. cruzi nesses ambientes (FORATTINI et alii, 1977, 1979 e 1984).

Dados relativos ao Programa de Controle no Estado, também apontaram estas características, havendo diferenças entre as duas espécies quanto à densidade de colonização nos ambientes e nos índices de infecção natural (WANDERLEY, 1994b). Dessa forma, $\boldsymbol{P}$. megistus tem apresentado maiores taxas de infecção por $T$. cruzi, contrastando com uma menor freqüência no ambiente domiciliar. Em outras regiões do país, comportamento semelhante também tem sido assinalado. Assim, DIOTAIUTI et alii (1993) mostraram, em algumas regiōes do Estado de Minas Gerais, que $T$. sordida e $\boldsymbol{P}$. megistus são espécies que têm predominado nas casas de áreas rurais, depois da eliminação do $T$. infestans no intradomicilio. FERNANDES et alii (1992) mostraram a possibilidade do $\boldsymbol{P}$. megistus reintroduzir a transmissão natural da doença de Chagas em Bambui, MG. A captura, na região, de exemplares parasitados por $T$. cruzi, pertencentes aos Zimodemas $Z 1$ e Z2, sugere que essa espécie esteja atuando como elemento de ligação entre os diferentes ciclos epidemiológicos de transmissão.

\section{Avaliação do potencial de domiciliação de triatomíneos:}

No presente estudo, o potencial de domiciliação de triatomíneos foi demonstrado pela colonização de adultos e ninfas de $\boldsymbol{P}$. megistus em ecótopo artificial, utilizando-se galinheiro experimental instalado em um 
resíduo de mata no sítio Carandá, localizado a $12 \mathrm{Km}$ da área urbana do município de Araraquara, região do Planalto Ocidental Paulista.

Segundo FORATTINI et alii (1980a), a tendência dessa espécie em ocupar ecótopos artificiais parece estar relacionada com as alterações ambientais, responsáveis pela diminuição das matas úmidas e pelas características climáticas regionais, definidas por inverno seco e verão chuvoso. Nestas condições $\boldsymbol{P}$. megistus mantém este comportamento em ambientes de matas residuais ou, até mesmo, em pequenas áreas florestadas. Os resultados obtidos na área em estudo, onde o galinheiro foi instalado e onde tem sido demonstrada a domiciliação triatomínica vem confirmar essas observações.

Quanto à infecção natural por $T$. cruzi, essa não foi observada sendo a pesquisa de tripanossomos nas fezes dos triatomíneos realizada por amostragem, sugerindo ser baixa a circulação do parasita na área. Por questões operacionais não foram instalados galinheiros experimentais nas regiões do Vale do Ribeira e Litoral Norte. Mas, dados da literatura mostram que, em áreas florestais mais preservadas do domínio tropical atlântico, como nesses casos, a domiciliação triatomínica em ecótopos artificiais não tem ocorrido (FORATTINI et alii 1980a). Porém, infecção natural por T. cruzi já foi assinalada em triatomíneos adultos, capturados no ambiente humano, em áreas rurais dos municipios do Vale do Ribeira e Litoral, demonstrando, desta forma, a circulação enzoótica do flagelado nestas regiões (CIARAVOLO et alii, 1997). 
Indiscutivelmente, o controle da transmissão vetorial no Estado de São Paulo fez com que a doença de Chagas deixasse de ser um problema de Saúde Pública. Neste processo, foram gerados profundos conhecimentos sobre populações triatomínicas e suas interrelaçð̃es com o ambiente humano, que serviram de base e, até mesmo, nortearam as ações de controle e vigilância. No entanto, informações sobre animais reservatórios e populações de T. cruzi que circulam em ambientes remanescentes não foram produzidas na mesma intensidade. Foi dentro desta perspectiva que o presente estudo foi direcionado, qual seja, o de contribuir para o reconhecimento dos animais reservatórios responsáveis pela manutenção da zoonose e a identificação dos flagelados neles encontrados, para que esses conhecimentos possam servir de apoio ao Programa de Vigilância Epidemiológica. Principalmente, devido a existência, no Estado, de focos naturais preservados, em áreas de antiga transmissão e sob controle, e de focos ainda desconhecidos em áreas consideradas indenes e que merecem a atenção por parte da vigilância epidemiológica.

\section{Animais silvestres:}

A infecção natural pelo $T$. cruzi em reservatórios animais tem sido observada e estudada na maioria dos paises do Continente Americano (BARRETTO, 1985), mesmo em regiões onde a tripanossomíase não é endêmica (KARSTEN et alii, 1992; KIRCHHOFF, 1993). Segundo a OMS (1991), já foram descritas mais de 150 espécies e subespécies de animais silvestres, sinantrópicos e domésticos infectados pelo protozoário. 
BARRETTO e RIBEIRO (1979) em trabalho de revisão já haviam reconhecido, no entanto, mais de 200 espécies de mamiferos distribuídos desde os Estados Unidos da América até a Argentina. No Brasil, a infecção natural pelo flagelado já foi constatada em aproximadamente um quarto das espécies de animais reservatórios descritas para o Continente.

Os mamíferos pertencentes às ordens Marsupialia e Rodentia são os reservatórios mais importantes de $T$. cruzi. A importância desses animais tem sido assegurada por apresentarem características como: capacidade em colonizar ecótopos naturais e artificiais variados, alta densidade, ampla distribuição geográfica, alto grau de relacionamento com espécies triatomínicas transmissoras e elevadas taxas de infecção natural, (BARRETTO, 1985; MELLO et alii, 1982; SCHLEMPER et alii, 1985).

Neste estudo, os animais procederam de ambientes silvestres, exceto os roedores do gênero Rattus, que foram capturados em áreas de matas próximas aos domicilios. Os mamíferos da ordem Marsupialia representaram $53,5 \%(106 / 198)$ do total de animais capturados. As espécies dos Gêneros Didelphis e Philander foram as mais freqüentes, com taxas de captura de $31,3 \%(62 / 198)$ e $17,7 \%(35 / 198)$, respectivamente. Quanto à distribuição desses animais, houve diferenças específicas para cada região. Assim, D. albiventris representou a espécie predominante na região do Planalto Ocidental Paulista 51,6\% (47/91), já D. marsupialis teve sua ocorrência assinalada no Vale do Ribeira (municipios de Eldorado e Iguape) e Litoral Norte; perfazendo $25,0 \%(11 / 44)$ e $6,3 \%(4 / 63)$ do total das capturas nas duas regiões, respectivamente. Da mesma forma, Philander opossum 
foi especie predominante no Litoral Norte, com indice de captura de $54,0 \%$ (35/63).

Os mamíferos da ordem Rodentia representaram 43,9\% (87/198) do total de animais estudados. Este grupo apresentou maior diversidade de espécies, sendo os gêneros Akodon, Proechimys e Oryzomys os mais freqüentes, com taxas de capturas de $14,1 \%(28 / 198), 7,1 \%(14 / 198)$ e $5,1 \%$ (10/198), respectivamente. Como observado na ordem Marsupialia, os roedores também apresentaram diferenças quanto à distribuição geográfica das espécies. Assim, a ocorrência do gênero Akodon foi assinalada no Planalto Ocidental Paulista e Vale do Ribeira, com índices de capturas de 20,9\% (19/91) e 20,4\% (9/44), respectivamente. Já a espécie Proechimys iheringi predominou no Litoral Norte, correspondendo a $22,2 \%$ (14/63) das capturas, enquanto que Oryzomys foi encontrado, exclusivamente, no Vale do Ribeira, representando $22,7 \%$ (10/44) dos animais capturados na região.

Os mamiferos da ordem Carnivora apresentaram menores índices de captura, $2,5 \%$ (5/198), sendo representados por exemplares do gênero Nasua, procedentes da região do Planalto Ocidental Paulista. Cabe ressaltar que a metodologia adotada nas capturas dos animais silvestres, com o emprego de armadilhas do tipo Tomahawk e Sherman, como também, os tipos de iscas utilizadas favoreceram as capturas de marsupiais e roedores.

Durante o período de capturas dos reservatórios algumas tentativas foram feitas para localizar refúgios naturais de Didelphis e roedores, com o intuito de encontrar triatomineos associados e estudar os tripanossomos neles encontrados. Mesmo que esta atividade não tenha sido realizada de 
maneira sistemática, na maioria das vezes, falharam em revelar tais refúgios, mas quando encontrados não apresentaram triatomineos.

Resultados diferentes foram relatados por vários autores em outras regiōes do pais. Assim, MELLO (1981) encontrou 24\% dos biótopos silvestres com triatomíneos, em áreas não endêmicas para a doença cie Chagas, na região de cerrado do Estado de Goiás. Já, em área endêmica do mesmo Estado, este índice alcançou 34,2\% (MELLO, 1982). SCHLEMPER Jr et alii (1985), no Estado de Santa Catarina, encontraram triatomíneos em cerca de $25 \%$ dos ninhos de animais silvestres examinados. MILES (1976), ao testar um novo dispositivo para seguimento de animais silvestres no interior de florestas, encontrou triatomíneos em $20 \%$ dos refúgios naturais localizados. É possível que diferenças metodológicas utilizadas para a localização dos biótopos e na coleta dos triatomíneos sejam responsáveis pelos resultados discrepantes.

\section{Pesquisa de flagelados em animais silvestres:}

No decorrer dos procedimentos para isolamento de $T$. cruzi em animais silvestres, foram constatadas infecçōes por outros flagelados pertencentes aos gêneros Leishmania e Trypanosoma. Dos 30 (15,1\%) animais que apresentaram flagelados, em, pelo menos um procedimento, 6 $(20,0 \%)$ não foram identificados por falta de dados que permitissem um diagnóstico correto.

De um roedor da espécie $\boldsymbol{P}$. iheringi, procedente do município da Ilhabela, Litoral Norte, foi isolado protozoário do sub-gênero $L$. 
(Leishmania). Cabe ressaltar que, na mesma região, durante a investigação de campo, foram diagnosticados, por outro grupo de trabalho, casos humanos e caninos de Leishmaniose Cutânea Americana devido à $L$. (Viannia) braziliensis. Este dado mostra a existência de diferentes subgêneros de Leishmania circulando na região (TOLEZANO et alii, 1999̄). Essa característica epidemiológica já foi assinalada em outras áreas do Estado de São Paulo, tendo como reservatórios descritos, roedores dos gêneros Oryzomys e Akodon (FORATTINI et alii, 1973; TOLEZANO et alii, 1988) e marsupial da espécie D. marsupialis (YOSHIDA et alii, 1979).

A identificação presumivel de $T$. freitasi foi baseada em critérios morfológicos dos tripomastigotas sangüíneos e no comportamento biológico. Apesar de ser constatada baixa parasitemia, $T$. freitasi foi detectado no sangue circulante de $7(87,5 \%)$, dos 8 animais parasitados. O não desenvolvimento em triatomíneos e a dificuldade no isolamento e na manutenção dos flagelados em meio de cultura acelular, foram outras características observadas que confirmaram os relatos de outros autores (REGO et alii, 1957; Deane, 1964; Silva et alii, 1976).

Ao que tudo indica, $T$. freitasi apresenta uma especificidade quanto ao hospedeiro vertebrado. O primeiro encontro do flagelado foi descrito por REGO et alii (1957), no município de Ribeirão Preto, Estado de São Paulo, no sangue de exemplares de $D$. albiventris. Posteriormente, DEANE (1964) registrou o encontro do protozoário em um $\boldsymbol{D}$. marsupialis capturado na região amazônica. Mais recentemente, DEANE e JANSEN (1986) assinalaram o encontro dessa espécie no conteúdo das glândulas anais de 
D. marsupialis, provenientes do Estado do Rio de Janeiro, mostrando que este comportamento não se restringe somente ao $T$. cruzi.

Na presente investigação, $T$. freitasi foi observado em mamiferos da ordem Marsupialia, sendo $6 \mathrm{D}$. albiventris e 2 Gracilinanus sp (antigo gênero Marmosa), todos capturados no municipio de Araraquara, região do Planalto Ocidental Paulista (Figura 3 A). A taxa de infecção geral foi de $9,8 \%$ (9/91), não sendo observado parasitismo associado com outros tripanossomos. Já, DEANE e JANSEN (1990) encontraram em $D$. marsupialis, taxas de infecção de $38,7 \%$, em alguns animais apresentando infecções associadas com $T$. cruzi. As diferenças observadas entre as taxas de infecçð̃es podem estar relacionadas com a metodologia do isolamento primário. THOMAZ e DEANE (1990), confirmaram as dificuldades no estabelecimento de cultivo "in vitro" quando utilizados meios bifásicos ou meios liquidos convencionais. Segundo os autores, só foi possível obter crescimento exuberante e contínuo dos flagelados quando utilizaram, para cultivo, linhagens de células de fibroblastos de camundongos.

A presença de tripanossomos do subgênero Herpetosoma foi constatada em dois roedores capturados no município de llhabela, sendo um P. iheringi e outro de espécie não identificada. Nesse subgênero está incluído, sobretudo, espécies de tripanossomos parasitas de roedores. Segundo BARRETTO e RIBEIRO (1981), este grupo de flagelados apresenta características comuns quanto à morfologia, biologia e especificidade em relação ao seus hospedeiros vertebrados. 
Neste estudo, as formas tripomastigotas sangüíneas, encontradas nos dois animais, eram semelhantes àquelas descritas para o referido subgênero (Figura 3 B). Não foram evidenciadas formas parasitárias de desenvolvimento intracelular através do exame das impressões de órgãos e do cultivo de vísceras. O exame das hemoculturas provenientes dos dois roedores apresentaram inicialmente flagelados, no entanto, não foi possivel a manutenção continuada desses protozoários. O fato do xenodiagnóstico ser negativo nos dois roedores parasitados, aliado a morfologia típica, vem reforçar o diagnóstico de tripanossomos pertencentes ao subgênero Herpetosoma.

Tentativas de estabelecimento de tripanossomos do subgênero Herpetosoma em meios de cultura convencionais sempre resultaram em insucessos (DEANE, 1961; BARRETO e RIBEIRO, 1981). Por outro lado, TOLEZANO et alii (1984) demonstraram que tripanossomos do subgênero Herpetosoma isolados de $\boldsymbol{P}$. iheringi, apresentavam intenso crescimento em meios de cultura convencionais, quando estes eram suplementados com sangue de vertebrados da espécie da qual foi obtido o isolamento.

\section{Infecção natural por T. cruzi em animais silvestres:}

Ao contrário de outros tripanossomos, T. cruzi apresentou um caracter eurixeno, ou seja, foi observado em marsupiais e roedores de diferentes espécies. Assim, a infecção natural por T. cruzi foi encontrada em 13 mamíferos capturados nas três regiões estudadas, sendo um $D$. albiventris, 5 D. marsupialis, 3 P. opossum, 3 P. iheringe e 1 Oryzomys 
sp. Todas as espécies animais, aqui encontradas, já foram assinaladas por outros autores em várias regiōes (BARRETTO e RIBEIRO, 1979; BARRETTO, 1985 ; OMS, 1991), não ocorrendo, desta forma, a descrição de novos reservatórios.

Houve nítida diferença nas taxas de infecção geral e por espécies de animais reservatórios nas três regiões estudadas. Desta forma, no Planalto Ocidental Paulista, município de Araraquara, o indice de infecção geral foi de $1,1 \%(1 / 91)$. Entre os animais do gênero Didelphis, este indice foi de $2,1 \%$ (1/47). Já, nos 33 roedores capturados, neste município, nenhum apresentou infecção por $T$. cruzi ou por outro tripanossomo. No Vale do Ribeira, nos municípios de Eldorado e Iguape, a taxa de infecção geral para T. cruzi foi de $11,4 \%(5 / 44)$. Entre os Didelphis, o indice de infecção foi de $36,3 \%$ (4/11) e, dentre os roedores, de 3,3\% (1/30). No Litoral Norte, município de Ilhabela, a taxa de infecção geral foi de $11,1 \%(7 / 63)$, semelhante à observada no Vale do Ribeira. Porém os índices de infecção variaram de 25,0\% (1/4) entre os Didelphis, 8,8\% (3/34) entre os Philander e, $21,4 \%$ (3/14) entre os Proechimys.

Cabe ressaltar que em Araraquara foi registrado o mais baixo índice de infecção natural entre animais reservatórios $(1,1 \%)$. Considerando que esta região foi marcada por grandes transformações econômicas, sociais e ambientais e, ainda, pelas ações do Programa de Controle da doença de Chagas, torna-se licito admitir que tais ocorrências possam ter repercutido sobre o ciclo de transmissão silvestre do $T$. cruzi. Isso pode significar que a área estudada represente um foco natural residual em extinção ou em plena 
dispersão. Por outro lado, não se pode deixar de considerar, também, como foco natural originalmente de baixa atividade. Já, nas regiões do Vale do Ribeira e Litoral Norte, onde a situação econômica e social tem sido mais estável e as alterações ambientais menos intensas, as taxas gerais de infecção natural foram de $11,4 \%$ a $11,1 \%$, respectivamente.

Recentemente, FERNANDES et alii (1999) observaram diferenças significativas nas taxas de infecções em Didelphis capturados em distintas localidades do Estado do Rio de Janeiro, mas pertencentes ao mesmo sistema ecológico (Mata Tropical Atlântica Costeira). Estes achados levaram os autores a concluír que, em relação à transmissão do $T$. cruzi, cada ecótopo representa uma unidade com características epidemiológicas próprias, não permitindo que se faça generalizações entre diferentes áreas em estudo.

Com relação aos índices de infecção por espécies, os dados aqui alcançados confirmam a importância dos marsupiais, sobretudo, do gênero Didelphis, na transmissão silvestre do $T$. cruzi. Para a espécie $D$. albiventris, MELLO (1982) encontrou índice de infecção de 20,6\% (15/73) em região de cerrado, no município de Mambaí, Estado de Goiás. Já, FERNANDES et alii (1991),em área sob Vigilância Epidemiológica para o controle da doença de Chagas, no Estado de Minas Gerais, obtiveram taxas de $37,9 \%$ (44/116). Para o Estado de Săo Paulo, BARRETTO e RIBEIRO (1979), em revisão detalhada, apontaram indices de infecção natural que variaram de $18,6 \%$ a $21,4 \%$, para vários municipios Paulistas. Da mesma forma, para D. marsupialis, os mesmos autores relataram taxas 
semelhantes de infecção para o Estado de São Paulo de 19,8\% e índices mais elevados de $91,7 \%$ e $35,7 \%$, em outros Estados.

Neste estudo, outro marsupial encontrado naturalmente infectado foi do gênero Philander, que apresentou uma freqüência de positividade de $8,8 \%(3 / 34)$ para os animais capturados no município de llhabela. Entre nos, DEANE (1964) descreveu pela primeira vez esta espécie como reservatório de $T$. cruzi em exemplares capturados na região amazônica. $O$ autor obteve taxa de $40 \%$ de infecção natural, mesmo em um pequeno número de espécimes capturada (2/5), ressaltando a importåncia desse gênero na transmissão silvestre do flagelado na região. Recentemente, FERNANDES et alii (1999) encontraram índice de infecção para este gênero de $43 \%$ (18/42), utilizando como técnica de isolamento a hemocultura, aplicada em animais procedentes de diversas localidades do Estado do Rio de Janeiro.

Em relação aos roedores, os dados aqui obtidos confirmam a menor importância do grupo, em relação aos marsupiais, na transmissão silvestre da tripanossomíase americana em algumas regiões. Assim, foram obtidos índices de infecção de $3,3 \%$ no Vale do Ribeira, com o encontro de 1 Oryzomys sp infectado entre os 30 animais examinados e, indice nulo para roedores capturados em Araraquara. Por outro lado, o encontro de $21,4 \%$ (3/14) de $\boldsymbol{P}$. iheringi naturalmente infectados, no município de Ilhabela, mostra que, para a região, esta espécie representa um elemento importante no ciclo enzoótico do flagelado.

Diferenças nas freqüências de infecção natural entre roedores silvestres já foram assinaladas por outros autores na mesma região e em 
regiões diferentes do país. MELLO (1981), no município de Formosa, Estado de Goiás, relatou o encontro de um exemplar de Calomys callosus, infectado entre 963 roedores estudados. Posteriormente, o mesmo autor verificou que, entre os 151 roedores capturados no município de Mambaí, Estado de Goiás, 2 Trychomys apereoides, 1 Zygodontomys lasiurus $\in 1$ C. callosus estavam infectados com T. cruzi (MELLO, 1982). No Estado de São Paulo, FORATTINI (1969) havia observado freqüência de infecção de 0,28\% para Akodon arviculoides e de $0,14 \%$ para Oryzomys nigripes, capturados em região de cerrado do municipio de Salto de Pirapora. Porém, BARRETTO e RIBEIRO (1979) apontaram cifras de $12,8 \%$ para Cavia aperea, 15,8\% para Dasyprocta azarae e $18,4 \%$ para A. arviculoides, capturados na região de Ribeirão Preto.

Por não ter sido possível isolar parasitas em dois roedores dos gêneros Proechimys e Oryzomys, o diagnóstico presumível da infeç̧ão natural por $T$. cruzi foi baseada, para a primeira espécie animal, no encontro de formas tripomastigotas metaciclicas nas fezes de ninfas de triatomíneos provenientes do xenodiagnóstico e, para a segunda espécie, no encontro de flagelados no exame direto e presença de formas amastigotas no baço. Nos outros onze animais, o diagnóstico da infecção por T. cruzi foi obtido a partir da caracterização biológica dos isolados por meio de critérios morfológicos, desenvolvimento dos flagelos em meio de cultura acelular e celular, evolução em animais de experimentação e em vetores. Para confirmação diagnóstica, foi usada metodologia molecular com análise do minicírculo de kDNA pela técnica de PCR. 


\section{Isolamento de $T$. cruzi em animais silvestres:}

O isolamento de $T$. cruzi foi obtido por 3 procedimentos diferentes. Desta maneira, a partir dos 11 animais silvestres, foram isoladas 16 amostras do protozoário, sendo $56,2 \%(9 / 16)$ delas por xenocultura, $25, \%$ (4/16) por hemocultura e $18,7 \%$ (3/16) pela cultura do material de aspirado de visceras. Dentre as técnicas utilizadas, a xenocultura foi a que apresentou melhor eficiência no isolamento das amostras. Este processo consistiu no cultivo, em meio acelular, do conteúdo intestinal de ninfas infectadas usadas no xenodiagnóstico. O bom desempenho do processo já foi constatado no isolamento de amostras humanas (BISUGO et alii, 1998) e de mamiferos silvestres capturados em outras regiões (PIETROKOVSKY et alii, 1991; WISNIVESKY-COLI et alii, 1992).

As variações na eficiência das três técnicas usadas para isolamento poderiam ser explicadas pelas baixas parasitemias observadas na maioria dos animais estudados. Assim, nos 11 animais, em que foi possível o isolamento de amostras do protozoário, 6 (54,5\%) não apresentaram flagelados no exame direto, indicando que, no momento da realização dos procedimentos, as parasitemias eram baixas ou subpatentes. Além disso, os animais foram submetidos aos três procedimentos no mesmo momento e em uma única vez. Neste sentido, RIBEIRO et alii (1984) demonstraram que, quando o xenodiagnóstico e a hemocultura foram empregados de forma seriada, em Didelphis naturalmente infectados por $T$. cruzi, ocorreu um aumento significativo na eficiência dos dois métodos. Segundo os autores, as parasitemias em animais com infecção natural são, geralmente, 
subpatentes e de longa duração, como observadas nas infecções humanas crônicas.

Tem sido demonstrado que isolados de $T$. cruzi, originários de casos humanos, de vetores e de animais silvestres, após período de adaptação em condições de laboratório, adquirem padrões de comportamento biológico bem definidos, relacionados com a morfologia, virulência, tropismo tecidual, entre outros. Essas caracteristicas biológicas representam apenas alguns dos critérios adotados no diagnóstico específico, na classificação e nos estudos de variabilidade dentro do grupo (ANDRADE, 1974; BRENER, 1985; MAGALHĀES e ANDRADE, 1991; ZINGALES et alii, 1997).

\section{Caracterização biológica dos isolados:}

O acompanhamento da infecção em animais de laboratório permite obter informações sobre a morfologia das formas sangüíneas, sobre a virulência, através do estabelecimento dos períodos pré-patente e patente, niveis de parasitemia e mortalidade, e sobre a patogenicidade, avaliada pela capacidade de invasão dos flagelados nos tecidos e pelas características das lesões produzidas nos órgãos. Desta forma, ANDRADE (1974) descreveu três padrões de comportamento em camundongos experimentalmente infectados com cepas de $T$. cruzi isoladas de casos humanos. Assim, esse autor estabeleceu que cepas do tipo I apresentam como características biológicas, a alta virulência, o predomínio de tripomastigotas delgadas e reticulotropismo no início da infecção e miotropismo aparecendo tardiamente; do tipo II, apresentam média 
virulência, o predomínio de formas tripomastigotas largas, com formas delgadas, aparecendo somente no inicio da infecção e com miotropismo predominante; e do tipo III, apresentam baixa virulência, com predomínio de formas largas e miotropismo em todo o curso da infecção.

Tem sido aceito que amostras isoladas de animais reservatórios, em geral, são menos virulentas para animais de laboratório do que as amostras isoladas de casos humanos ( BARRETTO, 1965; MELLO, 1979; FERNANDES et alii, 1991; HERRERA e URDANETA-MORALES, 1992; HERRERA e URDANETA-MORALES ,1997). Segundo BARRETTO (1965), os dados da literatura sobre o comportamento da infecção em animais de experimentação não podem ser comparados devido à falta de padronização dos ensaios. O autor aponta, como fatores que podem influenciar nos resultados, o inóculo (número e forma) e o animal de laboratório utilizado (idade, espécie e sexo). No entanto, mesmo dentro de condições padronizadas, tem sido observadas diferenças na evolução da infecção experimental entre amostras isoladas de diferentes espécies de animais silvestres, sobretudo de Didelphis, com a ocorrência de algumas amostras infectando camundongos e ratos e outras infectando somente ratos (BARRETTO et alii, 1980).

Considerando, no presente estudo, que foram usados isolados recentes, utilizou-se como inóculo $3 \times 10^{5}$ tripomastigotas metacíclicas obtidas de meio LIT, por animal e administradas pela via intraperitoneal. Nestas condições, todas as amostras infectaram animais de laboratório, havendo, no entanto, variações quanto ao comportamento da infecção 
conforme a espécie de animal de experimentação utilizada. Assim, foram observados três perfis de comportamento: perfil I. com parasitemias patentes em ratos e camundongos; perfil II. parasitemias patentes em ratos e subpatentes em camundongos e; perfil III. parasitemias baixas ou sub-patentes em ratos e ausentes em camundongos. As amostras de $T$. cruzi isoladas de Didelphis apresentaram os 3 perfis de comportamento, confirmando a existência de variações comportamentais entre os isolados de $T$. cruzi originários dessa espécie de reservatório. Já, as amostras isoladas de Proechimys e Philander apresentaram somente o perfil I.

No Didelphis E23, capturado no Vale do Ribeira, município de Eldorado, em que foi possivel isolar o flagelado pelas três metodologia (Eg23X, pela xenocultura; Eg23P, pela hemocultura e; Eg23F/B, pela cultura do material de aspirado de vísceras), as amostras apresentaram os três perfis de comportamento. Este dado mostra a possibilidade de seleção de diferentes populações de tripanossomos circulantes em um mesmo reservatório, quando utilizados diferentes procedimentos para o isolamento.

Admite-se que diferentes cepas de $T$. cruzi poderiam ser selecionadas de uma população heterogênea. O processo de seleção atuaria no ciclo de transmissão natural, explicando, desta forma, a predominância de certas populações de parasitas em diferentes regiões geográficas, ou em condições experimentais, determinadas pelas passagens seriadas em animais de laboratório ou em meios de cultura (DEANE et alii, 1984; CARNEIRO et alii, 1991). Experimentalmente, DEANE et alii (1984) demonstraram a co-existência de mais de uma população de $T$. cruzi no 
mesmo hospedeiro. Os autores, também, mostraram que o uso de diferentes esquemas de inoculação, re-inoculação e re-isolalamento, podem favorecer a circulação de uma ou de outra população de parasitas no hospedeiro. Por outro lado, alguns autores não constataram a seleção de subpopulações de T. cruzi, quando utilizado os processos de isolamento pelo xenodiagnóstıco ou pela hemocultura (ROMANHA et alii, 1989; FERNANDES et alii, 1991).

Considerando que, no presente estudo, o objetivo inicial da caracterização biológica foi verificar se os isolados apresentavam infectividade para ratos Wistar e/ou camundongos BALB/c, como critério de identificação de $T$. cruzi, o número de animais por experimento foi reduzido. Desta forma, foram utilizados como parâmetros os valores mínimos e máximos do período pré-patente e patente, os níveis máximos de parasitemias e a mortalidade. Pela análise destes parâmetros constantes nas Tabela 6 e 8, e dentro das condições de padronização dos experimentos, todos os isolados estudados apresentaram baixa virulência para animais de laboratório, concordando com os relatos de outros autores para animais silvestres já citados.

Como os niveis máximos de parasitemias em camundongos BALB/c e ratos Wistar foram baixos e, em alguns casos, não detectados no exame direto, foram utilizados animais das duas espécies submetidos à imunodepressão pela ciclofosfamida. Este procedimento teve a finalidade de induzir a elevação da parasitemia e do parasitismo tecidual. O esquema de imunodepressão foi baseado em experiência prévia, estabelecida pela Dra. Gentilda Kazuko Funayama Takeda, do Instituto de Ciências Biomédicas da 
USP (comunicação pessoal). A utilização de substância imunodepressora no esquema aqui preconizado proporcionou parasitemias mais elevadas em relação aos animais normais (Tabelas 7 e 9), facilitando o encontro dos flagelados no sangue e nos órgāos. Este procedimento representou um recurso útil nos estudos iniciais dos isolados de animais silvestres. Mesmo assim, nas amostras Ag5X e Ag5P, isoladas de um Didelphis capturado em Araraquara, a administração do imunodepressor não exacerbou as parasitemias. Cabe ressaltar, no entanto, que parâmetros como o período pré-patente, patente e mortalidade, sobretudo, em camundongos BALB/C, sofreram variações decorrentes, provavelmente, da utilização do imunodepressor.

Os aspectos morfológicos das tripomastigotas sangüineas representam o primeiro elemento de identificação entre os tripanossomos (BARRETTO, 1965; HOARE,1972). Contudo, a identificação baseada somente nas características morfológicas pode induzir a erros no diagnóstico, uma vez que há tripanossomos com características morfológicas semelhantes a $T$. cruzi. A biometria das formas encontradas no sangue do hospedeiro vertebrado fornece parâmetros como o comprimento do corpo e do flagelo que, juntos com o índice nuclear e do cinetoplasto, auxiliam na identificação de tripanossomos. Porém, BARRETTO (1965) chama à atenção de que esses dados só apresentam valores no diagnóstico especifico, quando são analisados com outros elementos. Segundo o autor, por existir variações acentuadas nas medidas dos flagelados em diferentes 
amostras isoladas de hospedeiro da mesma espécie e em uma mesma amostra, tal fato limita a utilização do parâmetro isoladamente.

As tripomastigotas sangüíneas têm mostrado grande variabilidade na morfologia ao longo da infecção aguda em animais de experimentação. Desta forma, os flagelados têm sido classificados em formas delgadas, intermediárias, largas e muito largas (BRENER e CHIARI, 1963; BRENER, 1985; SCHLEMPER et alii, 1986).

Cepas de $T$. cruzi mantidas por longos períodos em condiçð̃es experimentais, apresentam padrões de comportamento mais homogeneos, sendo usados como cepas de referência para estudos de caracterização, incluindo a morfobiológica. Assim a cepa $Y$, isolada de caso humano, tem como característica o predomínio de formas delgadas "clássicas" no início da fase aguda, apresentando, posteriormente, as formas intermediárias (ANDRADE, 1974). Já, na cepa CL, isolada a partir de fezes de triatomíneos, há predomínio das formas largas e muito largas (BRENER e CHIARI, 1963).

Tripomastigotas sangüíneas do tipo largo têm predominado na maioria das amostras de $T$. cruzi, isolados de casos humanos, triatomíneos e mamiferos silvestres (ANDRADE, 1974; BRENER e CHIARI, 1963; SCHLEMPER et alii, 1986). BRENER e CHIARI (1963) e, posteriormente, SCHLEMPER et alii (1986) apontaram o encontro de formas muito largas em amostras isoladas de triatomineos e animais silvestres procedentes da região Sul do país, sugerindo que este padrão morfológico possa representar uma característica regional. 
No presente trabalho, os tipos morfológicos foram estudadas ao longo da infecção experimental, como assinalado na Tabela 10. Foi observado polimorfismo, predominando, em todos os isolados, as formas intermediárias e largas. Formas muito largas apareceram no final da infecção, em amostras isoladas de Didelphis, sobretudo originárias do Vale do Ribeira, região sudeste do Estado de São Paulo. É possivel que este dado venha reforçar a sugestão de que tripomastigotas sangüíneos do tipo muito largos, possam ter distribuição regional mais restrita.

O encontro de formas delgadas "clássicas" na amostra Eg23X, isolada de Didelphis, não teve, ao que tudo indica, relação com o aumento da virulência na infecção experimental. Este achado, no entanto, difere dos dados da literatura, onde as formas delgadas estão associadas à intensa reprodução tecidual, parasitemias elevadas e ascendentes e, alta mortalidade (BRENER ,1985). É possível que o resultado, aqui alcançado, tenha sido influenciado pelo seu recente isolamento. Neste sentido, BRENER e CHIARI (1963) relataram, por exemplo, que para a amostra CL, atingir níveis elevados de parasitemia em camundongos albinos foram necessárias 25 passagens, nesses animais, com intervalos de 8 a 10 dias entre elas.

O encontro de parasitas nos tecidos, como assinala a Tabela 11, reafirma a infectividade das 16 amostras de $T$. cruzi, isoladas de animais silvestres. Apesar do encontro de amastigotas na medula óssea, fígado e baço, de intensidade variável, na maioria das amostras estudadas, o coração foi o órgão mais infectado, sendo constatada a presença do parasita 
em $15(93,7 \%)$ das 16 amostras estudadas. Elevada intensidade de parasitismo foi observado, neste órgão, nos isolados Eg23X, Eg23P e Eg31P, todos de Didelphis. Desta forma, os dados evidenciam um maior tropismo para a musculatura cardíaca, como já apontado por diferentes autores, para amostras isoladas de animais silvestres (MELLO et alii, 1979; BARRETTO et alii, 1980; HERRERA e URDANETA-MORALES, 1997). Notase porém, que, nas amostras isoladas de Proechimys e Philander, houve igual tropismo, tanto para o coração, quanto para órgãos ricos em macrófagos como medula óssea, figado e baço. Este "duplo tropismo", provavelmente, deve estar relacionado com a heterogeneidade das formas sangüineas encontradas. Com relação a esse aspecto, vários autores já mostraram, na infecção experimental, uma associação direta entre formas delgadas com parasitismo de macrófagos e formas largas com parasitismo cardíaco (ANDRADE, 1974; BRENER, 1985).

A técnica de impressão de órgãos "imprint" fornece uma idéia da capacidade de invasão dos flagelados em diferentes tecidos, não permitindo, no entanto, avaliar as características das lesões produzidas. Mas, estudos histopatológicos das amostras de $T$. cruzi isoladas de animais silvestres e de baixa virulência, em modelos experimentais murinos, têm mostrado padrões de lesões semelhantes às observadas na infecção natural em humanos e, na infecção experimental com cepas de origem humana ( MELLO, 1978).

Com relação à cultivabilidade, em geral, todos os isolados apresentaram crescimento expressivo em meio LIT. A má adaptação inicial 
observada na amostra Ig42X pode estar relacionada com as condições de criopreservação ou de descongelamento do isolado primário. Após o período de adaptação, foi possivel a manutenção continuada, em meio LIT, das 16 amostras de $T$. cruzi, mediante repiques sucessivos, com intervalos semanais. Estes dados concordam com a literatura, onde amostras de $T$. cruzi, isoladas de casos humanos, triatomíneos e animais silvestres apresentam um bom desenvolvimento em meios artificiais bifásicos ou liquidos (CAMARGO, 1964; CHIARI,1974; BARRETTO, 1980).

Os tipos morfológicos das tripomastigotas metacíclicas guardaram relação com o hospedeiro de origem, com o comportamento da infecção em animais de laboratório e, com a taxa de metaciclogênese. Assim, as tripomatigotas metaciclicas grandes e com membrana ondulante, por vezes, destacada do corpo, foram predominantes nos isolados de Didelphis, com exceção das amostras Eg23X e Ig42X. A evolução da infecção experimental, destas amostras, apresentou os perfis II e III, ou seja, determinou parasitemias sub-patentes ou ausentes em camundongos $B A L B / c$, diferentemente das amostras com predomíneo de tripomastigotas metacíclicas médias que apresentaram somente o perfil I. Além disso, houve diferenças acentuadas nas taxas de metaciclogênese em função do tempo de cultivo. Assim, a diferenciação das formas epimastigotas em tripomastigotas ocorreram a partir do $4^{\circ}$ dia de cultivo para as amostras de Didelphis, com exceção, novamente, dos isolados Eg23X e Ig42X. Estes achados sugerem a existência de, pelo menos, duas populações de 
tripomastigotas metacíclicos originários de animais silvestres, que puderam ser diferenciadas por caracteristicas morfobiológicas.

Vale salientar, ainda, que YOSHIDA (1983) demonstrou diferenças na constituição antigênica e na suscetibilidade à lise mediada por complemento, em tripomastigotas metacíclicas de várias cepas de T. cruzi. Segundo o autor, extrato de tripomastigotas da cepa $G$, isolado de marsupial da região Amazônica, apresentou marcadas diferenças na composição dos antígenos de superficie, quando comparado com as cepas virulentas $Y$ e $C L$, isoladas de casos humanos e de triatomíneos, respectivamente. Da mesma maneira, as cepas $\mathrm{Y}$ e $\mathrm{CL}$, foram resistentes à lise "in-vitro" por anti-soro contra a forma metacíclica. Já, no mesmo ensaio, as tripomastigotas da cepa G foram completamente lisadas pelo mesmo anti-soro. Sugeriu, o autor, que essas características imunológicas podem ser usadas como critérios na distinção entre cepas virulentas e não virulentas.

Foi demonstrado que todas as amostras estudadas evoluíram no tubo intestinal de triatomíneos. Este dado aliado à ausência de flagelados na hemolinfa e glândula salivar dos insetos, reforça o diagnóstico de $T$. cruzi. Porém, há de se destacar que, segundo BARRETTO (1965), apesar do $T$. cruzi apresentar bom desenvolvimento no intestino de triatomíneos, esta caracteristica não é exclusiva da espécie, existindo outros tripanossomos como $T$. sanmartini e $T$. diasi que podem evoluir no mesmo vetor, produzindo formas metacíclicas no intestino posterior.

No estudo do desenvolvimento dos tripanossomos nos vetores, notase que os indices de positividade foram relativamente baixos. Esses dados 
são significativos, uma vez que os xenodiagnósticos foram aplicados, na maioria dos animais de experimentação, na fase de parasitemia patente, onde foram observadas, com exceção do Eg23X, formas intermediária, larga e muito larga, que são mais adptadas ao vetor. Neste caso, é possível que fatores ligados ao parasita, ao triatomíneo ou, até mesmo, à metodologia possam ter influenciado nos resultados. Neste sentido, têm sido relatadas variações na positividade do xenodiagnóstico, conforme a espécie de triatomineo usada, tanto na infecção humana como em animais silvestres (ALVARENGA e BROFEN et alii, 1984; BORGES-PEREIRA et alii, 1996b; RIBEIRO et alii, 1984). Diferenças de infectividade entre cepas de $T$. cruzi e diferentes espécies de vetores foram mostradas por PERLOWAGORASZUMLEWICZ et alii (1990). Assim, os autores encontraram uma associação entre alta infectividade de cepas de $T$. cruzi do tipo biológico II e Zimodema Z2, e baixa infectividade para cepas do tipo III e Zimodema Z1.

Além disso, outros parâmetros relacionados com a interação do $T$. cruzi no trato intestinal do vetor podem influenciar na suscetibilidade entre as espécies de triatomíneos (GARCIA e AZAMBUJA, 1991). Desta forma, o número minimo de flagelados requeridos para a infecção dos triatomineos e a atividade lítica existente no intestino dos artrópodes, após alimentação, são alguns fatores que podem influenciar na inter-relação entre o parasita e seu vetor (GARCIA e AZAMBUJA, 1991).

Pelo exposto, os critérios morfobiológicos permitiram classificar os 16 isolados de animais reservatórios como $T$. cruzi, uma vez que: a) os tripanossomos evoluiram bem em meios de cultura acelulares com o 
aparecimento de formas metacíclicas características dessa espécie; b) as formas metaciclicas infectaram animais de laboratório, produzindo parasitemias patentes e sub-patentes; c) os tripanossomos sangüineos apresentaram aspectos morfológicos concordantes com a descrição de $T$. cruzi; d) foram observadas formas amastigotas nos órgãos dos animais de experimentação; e) ninfas de triatomineos, alimentadas em animais experimentalmente infectados, eliminaram tripomastigotas metaciclicas nas fezes, e estas formas não foram observadas na hemolinfa e glândulas salivares.

\section{Identificação molecular pelo minicírculo de kDNA:}

A técnica de PCR para amplificação de seqüência de minicírculo de kDNA com os "primers" P35/P36, foi utilizada com o propósito de avaliar um método molecular para a identificação de amostras de tripanossomos isolados de animais silvestres, já que, até o momento, a maioria dos métodos descritos para o diagnóstico molecular de $T$. cruzi foram aplicados em amostras humanas e de triatomíneos. Neste caso, os 16 isolados foram confirmados como T. cruzi, pela visualização de banda específica de 330 pb (Figura 9). Estes dados são concordantes com os parâmetros biológicos já apresentados e confirmam os relatos de outros autores, que consideram o produto de $330 \mathrm{pb}$, derivado da amplificação de uma seqüência que abrange uma região variável e parte de uma região conservada do minicírculo de KDNA, como sendo espécie especifica e cepa independente (STURM et alii, 1989; AVILA et alii, 1990; AVILA et alii, 1993). 
A obtenção da banda de aproximadamente $400 \mathrm{pb}$ em todos os isolados silvestres, incluindo o controle cepa $G$, representa um dado novo. Levando em consideração a padronização do ensaio, o encontro deste produto poderia representar um marcador de cepas de animais silvestres. No entanto, o verdadeiro significado deste achado só poderá ser avaliado, em futuros estudos, pelo uso de ensaios de hibridização com sondas especificas.

STURM et alii (1989), ao utilizarem o mesmo grupo de "primers" na amplificação de minicírculo de kDNA da cepa $C L$, isolada de $T$. infestans e das cepas Y e Peruana, isoladas de casos humanos, obtiveram um único fragmento de $330 \mathrm{pb}$. Posteriormente, AVILA et alii (1990) estenderam o estudo para 56 amostras de $T$. cruzi isoladas de casos humanos, animais reservatórios e triatomineos procedentes do Brasil, Venezuela, Colômbia e Costa Rica, e obtiveram os mesmos resultados. Por outro lado, já foi demonstrado que a amplificação de seqüências não esperadas pode ser obtida, com o mesmo grupo de "primers", quando mudanças no protocolo de extração de DNA e nas condições da técnica de PCR são introduzidas (GOMES et alii, 1998).

\section{Caracterização molecular pelo gene de mini-exon:}

A amplificação pela técnica de PCR de uma seqüência variável, localizada na região não transcrita do gene de mini-exon de $T$. cruzi, resulta em produtos de 300 ou 350 pb, indicando a existência de dimorfismo nesta seqüência gênica entre isolados dessa espécie. Essa característica também 
foi observada na seqüência do gene $24 S \alpha$ rDNA, outro marcador genético que apresenta dimorfismo entre isolados de T. cruzi (SOUTO et alii. 1996).

As diferenças nas seqüências gênicas observadas com esses marcadores, têm permitido agrupar amostras de $T$. cruzi, isoladas de casos humanos, triatomíneos e animais reservatórios, em dois grupos designados T. cruzi I e T. cruzi II; existindo, porém, um agrupamento hibrido que apresenta um duplo genótipo (SOUTO et alii, 1996; FERNANDES et alii, 1998a). Estudos de variabilidade genética, pela técnica de RAPD, de isolados pertencentes aos dois grupos mostraram a existência de ampla distância filogenética, suficiente para separa-los em duas linhagens (SOUTO et alii, 1996; ZINGALES et alii, 1998).

Do ponto de vista filogenético, a origem desses grupos ainda não está esclarecida. No entanto, admite-se duas hipóteses: a primeira, considerando a existência de ancestrais distintos que evoluiram separadamente, tendo o grupo híbrido surgido como conseqüência de uma transferência genética do T. cruzi I para T. cruzi II. A segunda, considerando a evolução a partir de ancestral comum, pertencente ao grupo $T$. cruzi I, que divergiu durante a evolução clonal em $T$. cruzill e no grupo hibrido (SOUTO et alii, 1996).

Mais recentemente, FERNANDES et alii (1998b) mostraram que algumas amostras de $T$. cruzi, isoladas da região Amazônica, não puderam ser classificadas como T. cruzi I ou T. cruzi II, quando utilizado, como marcador, o gene de mini-exon. Segundo os autores estes isolados seriam classificados como uma sub-linhagem derivada do $T$. cruzi I, a qual estaria relacionada com o Zimodema $Z 3$. 
Para um melhor entendimento da questão, vários autores têm procurado investigar a distribuição dos dois genótipos em reservatórios vertebrados e invertebrados. Desta forma, estudos epidemiológicos usando marcadores de genes ribossômicos têm mostrado uma associação preferencial de $T$. cruzi II, com o ciclo de transmissão doméstica e de $T$. cruzi I, com o ciclo de transmissão silvestre (ZINGALES et alii, 1998; FERNANDES et alii, 1998a).

FERNANDES et alii (1999) encontraram os dois grupos de $T$. cruzi co-existindo no mesmo ambiente natural, demonstrando ser o ciclo de transmissão silvestre mais complexo do que o admitido. Associações dos dois genótipos com as espécies de reservatórios naturais também foram observadas. Assim, D. marsupialis, capturados em áreas silvestres do Estado do Rio de Janeiro, apresentaram flagelados do tipo T. cruzi I ou de linhagem hibrida, enquanto que em isolados de $\boldsymbol{P}$. opossum foram encontrados os tipos T. cruzi I e T. cruzi II. Entre os primatas, capturados na mesma região, todos os isolados foram reconhecidos como do tipo $T$. cruzi II. No mesmo estudo, os isolados de triatomíneos, também, apresentaram associações preferênciais, sendo todos os isolados de Rhodnius sp classificados como T. cruzil e de Triatoma vitticeps como $T$. cruzi II.

No presente estudo, foi possivel agrupar amostras de $T$. cruzi isoladas de animais silvestres, nos dois genótipos já descritos e em um grupo de isolados não classificado por essa metodologia (Figura 10). Das 9 amostras isoladas de Didelphis, $7(77,8 \%)$ foram classificadas como do tipo 
T. cruzi I e $2(22.2 \%)$ como do tipo T. cruzi II. As duas amostras isoladas de um mesmo $D$. albiventris capturado no municipio de Araraquara, foram classificadas como $T$. cruzi I. Das 6 amostras isoladas de $D$. marsupialis capturados no municipio de Eldorado, 5 foram do tipo $T$. cruzi I e uma do tipo T. cruzi II. O isolado de D. marsupialis capturado no município de Ilhabela foi classificado como do tipo T. cruzi II. Os isolados de Proechimys e Philanders, originários dessa última região, não puderam ser definidos por essa metodologia. Esses achados confirmam a associação preferêncial do T. cruzi I com marsupiais do gênero Didelphis.

Caracteristicas genotípicas puderam ser relacionadas com algumas características biológicas. Deste modo, as amostras caracterizadas como $T$. cruzi I determinaram na infecção experimental de ratos e camundongos perfis de comportamentos II (parasitemias patentes em ratos e sub-patentes em camundongos) e III (parasitemias baixas ou sub-patentes em ratos e ausentes em camundongos). As amostras $T$. cruzi II e as que não foram definidas pelo marcador do gene de mini-exon apresentaram o perfil 1 (parasitemias patentes em ratos e camundongos). A metaciclogênese observada nos cultivos em meio LIT também apresentou relação com os genótipos. Os isolados $T$. cruzi I apresentaram maior taxa de metaciclogênese, que os isolados $T$. cruzi II e, nas amostras sem genótipo definido, as taxas foram intermediárias. Estes dados mostram uma similaridade no comportamento biológico entre os isolados de Didelphis do tipo T. cruzi II, com os isolados de Proechimys e Philanders. Contudo, uma possível relação destes últimos isolados com a sub-linhagem 
relacionada ao Zimodema $Z 3$ e ao ciclo de transmissão silvestre, como descrita na região Amazônica, não pode ser totalmente descartada, e será futuramente investigada com outros marcadores genéticos.

Muito embora seja reconhecida a divisão do taxon $T$. cruzi em pelo menos dois grupos, o verdadeiro significado desses genótipos necessitā de melhores esclarecimentos. Algumas evidências sugerem que T. cruzi II possa servir como fator de pré-disposição para o aparecimento da doença de Chagas em algumas áreas (SOUTO et alii, 1996). Assim, tem sido mostrado uma predominância desse grupo em espécies de triatomíneos encontrados no ambiente doméstico e peridoméstico.

Outra evidência relaciona-se com a associação dos diferentes genótipos e a infecção humana. FERNANDES et alii (1998a) mostraram que isolados humanos do tipo $T$. cruzi II predominam em áreas endêmicas onde há elevada soroprevalência e maiores percentuais de alterações eletrocardiográficas. Nas áreas indenes onde os casos humanos são esporádicos e as alterações eletrocardiográficas são menos freqüentes, como no caso da região Amazônica, há relatos de isolados humanos do tipo T. cruzi I e da sub-linhagem associada ao Zimodema Z3, ambas relacionadas ao ciclo de transmissão silvestre (FERNANDES et alii, 1998b). Nesse sentido, as linhagens poderiam ser usadas como marcadores epidemiológicos para os estudos de inter-relação dos ciclos de transmissão silvestre e domiciliar, visando avaliar o risco de restabelecimento do ciclo de transmissão domiciliar em áreas controladas ou no risco de sua introdução em áreas indenes. 
10. Polimorfismo genético entre tripanossomos isolados de animais silvestres:

Nesta investigação, o grau de variabilidade entre os isolados de $T$. cruzi foi avaliado pela técnica de RAPD. Essa metodologia tem sido amplamente utilizada em estudos populacionais de parasitas devido a sua capacidade de detectar polimorfismo mesmo entre organismos geneticamente relacionados e a sua simplicidade, uma vez que não há necessidade de informações prévias sobre as seqüências de DNA-alvo que serão amplificados nos ensaios (STEINDEL et alii, 1993; TIBAYRENC et alii, 1993).

As análises por RAPD confirmaram a existência de variabilidade genética entre os isolados de $T$. cruzi estudados. Os padrões de RAPD dos isolados $T$. cruzi I foram distintos dos observados nos isolados $T$. cruzi II, confirmando a existência de uma distância genética entre os grupos (Figura 13). Nas amostras pertencentes ao genótipo $T$. cruzi I foi observado um maior grau de similaridade entre elas. O mesmo não ocorreu com os isolados classificados como T. cruzi II, que apresentaram indices de similaridade inferiores quando comparados entre si (Tabela 15). De maneira geral, os padrões de RAPD tenderam a ser similares nas amostras isoladas da mesma espécie de animal silvestre, originárias da mesma área geográfica e pertencentes ao mesmo genótipo (Figuras 11 A, 11 B, 12 A, 12 B). Esses dados, sugerem a existência de populações de $T$. cruzi mais homogêneas, quanto às caracteristicas genéticas, circulando em uma dada 
área geográfica. Mesmo assim, um número variado de genótipos individuais foi observado dentro de cada grupo.

\section{Consideraçōes finais:}

Devido ao pequeno número de isolados originários do Planalto Ocidental Paulista, município de Araraquara (antiga região endêmica), não foi possivel correlacionar as caracteristicas genéticas e biológicas com esta área geográfica. As duas amostras de $T$. cruzi, isoladas de um mesmo $D$. albiventris, foram caracterizadas como $T$. cruzi I, apresentando alta similaridade entre elas e mesmo comportamento biológico.

As amostras isoladas de animais reservatórios capturados no Vale do Ribeira, municipio de Eldorado (região indene), foram constituídas de isolados exclusivamente de Didelphis. Nesta região foi constatada a circulação das duas populações $T$. cruzi I e $T$. cruzi II, sendo que, de um mesmo animal foi possivel o isolamento dos dois genótipos, quando usadas metodologias diferentes. Assim, pela xenocultura foi isolada a amostra Eg23X, do tipo $T$. cruzi II e, pela hemocultura e cultura de aspirado de visceras foram isoladas as amostras Eg23P e Eg23F/B, ambas do tipo $T$. cruzi I. Nesse caso, os isolados diferiram tanto no grau de variabilidade genética quanto nas caracteristicas biológicas.

No litoral Norte, municipio de llhabela (área indene) houve maior diversidade de espécies de animais reservatórios naturalmente infectados por T. cruzi. As amostras isoladas foram de Didelphis, Proechimys e Philander. O isolado de Didelphis foi caracterizado como T. cruzi II e as 
demais não foram definidas pelo marcador genético utilizado. Este último grupo de isolados apresentou baixo grau de similaridade, pela técnica de RAPD, em relação aos tipos $T$. cruzi I (não encontrado na região) e $T$. cruzi II. Contudo, as características biológicas foram similares às encontradas nas amostras do tipo T.cruzi II. Destaca-se o fato da ausência do genótipo $T$. cruzi I circulando na região. É possível que neste caso, o isolamento geográfico tenha influência na circulação da população do flagelado na região. O real significado dos isolados de Proechimys e Philander serão esclarecidos em estudos futuros, utilizando-se outros marcadores moleculares e com maior número de isolados. 


\section{CONCLUSÕES}

1) O potencial de domiciliação de Panstrongylus megistus na antiga área endêmica do Estado de São Paulo, foi demonstrado pela colonização de ecótopo artificial. A infecção natural por T. cruzi nestes triatomíneos não foi observada, sugerindo ser baixa a circulação do parasita na área;

2) No decorrer dos procedimentos para isolamento de $T$. cruzi, foram constatadas infecções por outros flagelados pertencentes aos sub-gêneros

L. (Leishmania), T. (Herpetosoma) e T. (Megatrypanum).

3) Os indices de infecção natural para $T$. cruzi foram de 1,1\%, 11,4\% e $11,1 \%$ para as regióes do Planalto Ocidental Paulista, Vale do Ribeira e Litoral Norte, respectivamente;

4) Os indices de infecção natural por espécies confirmaram a importáncia dos marsupiais, sobretudo, do gênero Didelphis, na transmissão silvestre do T. cruzi;

5) Foram isoladas 16 amostras de tripanossomos de 11 animais pela xenocultura, hemocultura e/ou cultura do aspirado de vísceras. A xenocultura foi a técnica que apresentou melhor eficiência no isolamento das amostras;

6) Os critérios morfobiológicos permitiram identificar todas as amostras estudadas como T. cruzi. Assim, os isolados apresentaram baixa virulência para animais de laboratório; formas amastigotas foram encontradas na medula óssea, figado, baço e coração; as formas sangüineos apresentaram aspectos morfológicos concordantes com a 
descrição de T. cruzi; os tripanossomos evoluíram bem em meios de cultura acelulares e; infectaram ninfas de triatomíneos com presença de formas tripomastigotas metaciclicas nas fezes e ausentes na hemolinfa e glândulas salivares;

7) A amplificação de seqüência de minicírculo de kDNA dos 16 isolados pela técnica de PCR confirmou o diagnóstico de $T$. cruzi, revelando um produto espécie específico e cepa independente de 330pb;

8) Na caracterização molecular, a amplificação de um fragmento da região intergênica do gene de mini-exon, resultou, para os isolados de Didelphis, em produtos de 300 ou $350 \mathrm{pb}$. Desta forma, $77,8 \%$ foram classificados como T. cruzi I e $22,2 \%$ como T. cruzi II. Uma associação preferencial do genótipo $T$. cruzi I com marsupiais do gênero Didelphis foi observada;

9) Os isolados de Proechimys e Philander, todos procedentes do município de lihabela, não apresentaram os produtos esperados de 300 ou 350pb, não sendo possivel a definição dos genótipos T. cruzi l e T. cruzi II, pelo marcador molecular do gene de mini-exon;

10) Os padrões de RAPD demonstraram variabilidade entre os isolados pertencentes aos tipos T. cruzi I, T. cruzi II e no grupo sem genótipo definido. Maior similaridade foi observada entre as amostras pertencentes ao mesmo grupo. Foi possivel, também, agrupar os padrões de RAPD conforme a espécie de hospedeiro e a origem geográfica. 
11) Em um mesmo Didelphis foi possivel selecionar duas populações de flagelados que apresentaram características biológicas e genéticas distintas. 


\section{REFERÊNCIAS}

Acha PN, Szyfres B. Zoonosis y enfermedades transmisibles comunes al hombre y a los animales. Washington (DC); 1977 (OPS-Publicacción Cientifica, 354).

Alvarenga NJ, Bronfen E. Interação do Trypanosoma cruzi com diferentes vetores: uso para o xenodiagnóstico. Rev Soc Bras Med Trop 1984; 17: 145-9.

Andrade SG. Caracterização de cepas do Trypanosoma cruzi isoladas no Recôncavo Baiano. Rev Patol Trop 1974; 3: 65-121.

Avila $H$, Gonçalves AM, Nehme NS, Morel CM, Simpson L. Schizodeme analysis of Trypanosoma cruzi from South and Central America by analysis of PCR-amplified minicircle variable region sequences. Mol Biochem Parasitol 1990; 42: 175-88.

Avila $H$, Pereira JB, Thiemann $O$, De Paiva E, Degrave W, Morel CM, Simpson L. Detection of Trypanosoma cruzi in blood specimens of chronic chagasic patients by polymerase chain reaction amplification of kinetoplast minicircle DNA: Comparison with serology and xenodiagnosis. J Clin Microbiol 1993; 31: 2421-6.

Barata JMS, Rocha RM, Rodrigues VLCC, Ferraz-Filho NA. Primeiro caso autóctone de tripanossomíase americana do Estado do Acre (Brasil) e sua correlação com as cepas isoladas do caso humano e de triatomineos silvestres da área. Rev Saúde Pública 1988; 22: 401-10.

Barretto MP. Tripanossomos semelhantes ao Trypanosoma cruzi em animais silvestres e sua identificação com o agente etiológico da doença de Chagas. Rev Inst Med Trop São Paulo 1965; 7: 305-15.

Barretto MP. Estudos sôbre reservatórios e vectores silvestres do Trypanosoma cruzi. XXII. Modificaçōes dos focos naturais da tripanossomose americana e sua consequências. Rev Soc Bras Med Trop 1967a; $1: 167-73$.

Barretto MP. Estudos sôbre reservatórios e vectores silvestres do Trypanosoma cruzi. XVII. Contribuição para o estudo dos focos naturais da tripanossomose americana, com especial referência à região nordeste do Estado de São Paulo, Brasil. Rev Soc Bras Med Trop 1967b; 2: 23-35.

Barretto MP, Ribeiro RD. Reservatórios silvestres do Trypanosoma (Schizotrypanum) cruzi Chagas, 1909. Rev Inst Adolfo Lutz 1979; 39: 25 36 . 
Barretto MP, Ribeiro RD, Ferriolli Filho F. Estudos sôbre reservatórios e vectores silvestres do Trypanosoma cruzi. LXXV: Estudo de amostras de $T$. cruzi isoladas de gambás do gênero Didelphis. Rev Bras Biol 1980; 40: $387-91$.

Barretto MP, Ribeiro RD. Estudos sobre tripanossomos do subgênero Herpetosoma Doflein, 1901 em roedores silvestres, com a descrição de três novas espécies. Rev Bras Blol 1981; 41: 485-97.

Bisugo MC, Araújo MFL, Nunes EV, Cunha EA, Oliveira Junior OC, Guilherme CS, et al. Isolamento de Trypanosoma cruzi por xenocultura após aplicação de xenodiagnóstico In vivo e/ou In vitro em pacientes na fase crônica da doença de Chagas e na co-infecção pelo HIV. Rev Inst Adolfo Lutz 1998; 57: 89-96.

Borges-Pereira J, Abreu LL, Aguilar HMV, Benites CDV, Coura JR. Avaliação da prevalência e da morbidade da infecção chagásica humana em áreas endêmicas dos Estados de Minas Gerais (Região Sudeste) e da Paraíba (Região Nordeste), Brasil, I. Contribuiçăo ao estudo do custo da doença de Chagas. Rev Soc Bras Med Trop 1996 a; 29 Supl 2: 107-9.

Borges-Pereira J, Junqueira ACV, Santa LC, Castro JAF, Araujo IB, Coura JR. Xenodiagnóstico na doença de Chagas crónica. I. Sensibilidade de Panstrongylus megistus e Triatoma infestans. Rov Soc Bras Med Trop 1996 b; 29: 341-7.

Brener $Z$. Therapeutic activity and criterion of cure of mice experimentally infected with Trypanosoma cruzi. Rev Inst Med Trop São Paulo 1962; 4: 389-96.

Brener Z, Chiari E. Variaçőes morfológicas observadas em diferentes amostras de Trypanosoma cruzi. Rev Inst Med Trop São Paulo 1963; 5: $220-4$.

Brener Z. General review on Trypanosoma cruzi classification and taxonomy. Rev Soc Bras Med Trop 1985; 18 Supl 1: 1-8.

Camargo EP. Growth and differention in Trypanosoma cruzi. I. Origin of metacyclic trypanosomes in liquid media. Rev Inst Med Trop São Paulo 1964; 4: 93-100.

Cenargo ME, Silva GR, Castilho EA, Silveira AC. Inquérito sorológico da prevalência de infecção chagásica no Brasil 1975/1980. Rev Inst Med Trop São Paulo 1984; 26: 92-204.

Carneiro M, Romanha AJ, Chiari E. Biological characterization of Trypanosoma cruzi strains from different zymodemes and schizodemes. Mem Inst Oswaldo Cruz 1991; 86: 387-93. 
Cerqueira RL, Kawarabayashi M, Guimarães ACS, Nakamura PM, Ferraz SN, Pinto PLS, Andrade Jr HF. Santo Inácio revisited: Protozoan diseases in na isolated village in Northeastern Brazil after twenty years. Am J Med Hyg 1998; 59: 736-40.

Chiari E, Growth and differentiation of Trypanosoma cruzi culture forms kept in laboratory for different periods of time. Rev Inst Med Trop São Paulo 1974; 16: 81-7.

Ciaravolo RMC, Domingos MF, Wanderley DMV, Gersi LJ, Chieffi PP, Peres BA, Umezawa ES. Autochthonous acute Chagas' disease in São Paulo State, Brazil. Epidemiological aspects. Rev Inst Med Trop São Paulo 1997; 39: $171-4$.

Clark CG, Pung OJ. Host specificity of ribosomal DNA variation in sylvatic Trypanosoma cruzi from North America. Mol Biochem Parasitol 1994; 66: 175-9.

Correa, RR, Lima FC, Carvalho PL. Da infecção natural pelo Trypanosoma cruzi nas ninfas e adultos do Triatoma infestans. Arq Hig Saúde Pública Univ São Paulo 1952; 17: 9-14.

Coura JR, Fernandez O, Arboleda M, Barett TV, Carrara N, Degrave W, Campbell, DA. Human infection by Trypanosoma rangeli in the Brazilian Amazon. Trans R Soc Med Hyg 1996; 90: 278-9.

Coutinho, JO. Contribuição ao estudo da epidemiologia da doença de Chagas. Arq Hig Saúde Pública Univ São Paulo 1962; 27: 317-33.

Cuba Cuba AC Revisión de los aspectos biológicos y diagnósticos del Trypanosoma (Herpetosoma) rangeli. Rev Soc Bras Med Trop 1998; 31: 207-20.

Deane LM. Tripanosomídeos de mamíferos da Região Amazônica. I. Alguns flagelados encontrados no sangue de mamíferos silvestres do Estado do Pará. Rev Inst Med Trop São Paulo 1961; 3: 15-28.

Deane LM. Tripanosomídeos de maniferos da Região Amazônica. III Hemoscopia e xenodiagnóstico de animais silvestres dos arredores de Belém, Pará. Rev Inst Med Trop São Paulo 1964; 6: 225-32.

Deane MP, Lenzi HL, Jansen AM. Trypanosoma cruzi vertebrate and invertebrate cycles in the same mammal host the Opossum Didelphis marsupialis. Mem Inst Oswaldo Cruz 1984; 79: 513-5. 
Deane MP, Jansen AM. Another Trypanosoma, distinct from $T$. cruzi, multiplies in the lumen of the anal glands of the opossum Didelphis marsupialis. Mem Inst Oswaldo Cruz 1986; 81: 131-2.

Deane MP, Jansen AM. From a mono to digenetic life-cycle: How was the jump for flagellates of the family trypanisomatidae? Mem Inst Oswaldo Cruz 1988; 83: 273-5.

Deane MP, Jansen AM. Developmental stages of Trypanosoma (Megatrypanum) freitasi Rego, Magalhães \& Siqueira, 1957 in the opossum Didelphis marsupialis (Marsupialia, Didelphidae). J Protozool 1990; 37: 44-7.

Dias JCP. Aspectos socio-culturales y economicos relativos al vector de la enfermedad de Chagas. In: Carcavallo RU, Rabinovich JE, Tonn RJ. Factores biológicos y ecológicos en la enfermedad de Chagas. Buenos Aires; Ministério de Salud y Acción Social; 1985. V 2: Parasitos reservatorios - control - situacion regional.

Dias JCP. The control of Chagas diseases in Brazil. Parasitol Today 1987; 3: $336-41$.

Dias JCP. Estratégias e perspectivas atuais da consolidação do controle de vetores na etapa de vigiláncia epidemiológica. Rov Soc Bras Med Trop 1994; 27Supl 2: 63-6.

Dias JCP. Silveira AC. Situação atual da doença de Chagas no Brasil. Rev Soc Bras Med Trop 1996; 29 Supl 2: 63-6.

Dias JCP. O desafio da doença de Chagas nos centros urbanos. Rev Soc Bras Med Trop 1999; 32 Supl 2: 45-8.

Diotaiuti L, Loiola CF, Falcão PL, Dias JCP. The ecology of Triatoma sordida in natural environments in two different regions of the State of Minas Gerais, Brazil. Rev Inst Med Trop São Paulo 1993; 35: 237-46.

Diotaiuti L, Pereira AS, Loiola CF, Fernandes AL, Schofield JC, Dujardin JP et al. Inter-relation of sylvatic and transmission of Trypanosoma cruzi in areas with and without domestic vectorial transmission in Minas Gerais, Brazil. Mem Inst Oswaldo Cruz 1995; 90: 443-8.

Felsenstein J. PHYLIP - Phylogeny Inference Package (Version 3.2) Cladistics 1989; 5: 164-6.

Fernandes AJ, Diotaiuti L , Dias JCP, Romanha AJ, Chiari E. Infecção natural das glândulas de gambá (Didelphis albiventris) pelo Trypanosoma cruzi no município de Bambuí-MG. Mem Inst Oswaldo Cruz 1989; 84 : 87 93. 
Fernandes AJ, Chiari E, Rodrigues RR, Dias JCP, Romanha AJ. The importance of Opossum (Didelphis albiventris) as a reservoir for Trypanosoma cruzi in Bambui, Minas Gerais State. Mem Inst Oswaldo Cruz 1991; 86: 81-5.

Fernandes AJ, Chiari E, Casanova C, Dias JCP, Romanha AJ. The threat of reintroduction of natural transmission of Chagas'diseases in Bambui, Minas Gerais State, Brazil, due to Panstrongylus megistus. Mem Inst Oswaldo Cruz 1992; 87: 285-9.

Fernandes O, Murthy VK, Kurath U, Degrave WM, Campbell DA. Mini-exon gene variation in human pathogenic Leishmania species. Mol Biochem Parasitol 1994; 66: 261-71.

Fernandes O, Souto RP, Castro JÁ, Pereira JB, Fernandes NC, Junqueira $\mathrm{CV}$, et al. Brazilian isolates of Trypanosoma cruzi from humans and triatomines classified into two lineages using mini-exon and ribosomal RNA sequences. Am J Trop Med Hyg 1998a; 58: 807-11.

Fernandes O, Sturm NR, Derré R, Campbell DA. The mini-exon gene: A genetic marker for zymodeme III of Trypanosoma cruzi. Mol Biochem Parasitol 1998b; 95: 129-133.

Fernandes O, Mangia RH, Lisboa CV, Pinho AP, Morel CM, Zingales B, et al. The complexity of the sylvatic cycle of Trypanosoma cruzi in Rio de Janeiro state (Brazil) revealed by the non-transcribed spacer of the mini-exon gene. Parasitology 1999; 118: 161-6.

Forattini OP, Juarez E, Rabello EX, Pattoli D, Corrêa RR. Infestaçăo domiciliar por Triatoma infestans e alguns aspectos epidemiológicos da tripanossomíase americana em área do Estado de São Paulo, Brasil. Rev Saúde Pública 1969; 3: 159-72.

Forattini OP, Pattoli DBG, Rabello EX, Ferreira AO. Nota sobre a infecção natural de Oryzomys capito laticeps em foco enzoótico de Leishmaniose Tegumentar no Estado de São Paulo, Brasil. Rev Saúde Pública 1973; 6: 225-61.

Forattini OP, Rocha e Silva EO, Ferreira AO, Rabello EX, Santos JLF, Lima AR. Aspectos ecológicos da Tripanossomíase americana. XI. Domiciliação de Panstrongylus megistus e potencial enzoótico. Rev Saúde Pública $1977 ; 11: 527-50$.

Forattini OP, Ferreira AO, Rocha e Silva EO, Rabello EX. Aspectos ecológicos da Tripanossomiase americana. XIV. Persistência e potencial de domiciliação de populaçōes triatomínicas silvestres em região de intensa atividade agropecuária. Rev Saúde Pública 1979; 13: 123-46. 
Forattini OP. Biogeografia, origem e distribuição da domiciliação de triatomineos no Brasil. Rev Saúde Pública 1980a; 14: 265-99.

Forattini OP, Rocha e Silva EO, Barata JMS, Boainaim E. Nota sobre caso autóctone de Tripanossomiase americana no litoral sul do Estado de São Paulo, Brasil. Rev Saúde Pública 1980b; 14: 143-9.

Forattini OP, Rocha e Silva EO, Barata JMS, Boainaim E. Nota sobre novo caso autóctone de Tripanossomíase americana no litoral sul do Estado de São Paulo, Brasil. Rev Saúde Pública 1981; 15: 350-2.

Forattini OP, Rabello EX, Ferreira AO, Rocha e Silva EO, Santos JLF. Aspectos ecológicos da Tripanossomiase americana. XXI. Comportamento de espécies triatomíneas silvestres na reinfestação do intra e peridomicilio. Rev Saúde Pública 1984; 18: 185-208.

Frasch ACC, Goijman SG, Cazzulo JJ, Stoppani AOM. Constant and variable regions in DNA mini-circles from Trypanosoma cruzi and Trypanosoma rangeli: Application to species and stock differentiation. Mol Biochem Parasitol 1981; 4: 163-70.

Garcia ES, Azambuja P. Development and interaction of Trypanosoma cruzi within the insect vector. Parasitol Today 1991; $7: 240-4$.

Gomes ML, Macedo AM, Vago AR, Pena SDI, Galvão LMC, Chiari E. Trypanosoma cruzi: Optimization of polymerase chain reaction for detection in human blood. Exp Parasitol 1998; 88: 28-33.

Herrera L, Urdaneta-Morales S. Didelphis marsupialis: a primary reservoir of Trypanosoma cruzi in urban areas of Caracas, Venezuela. Ann Trop Med Parasitol 1992; 86: 607-12.

Herrera L, Urdaneta-Morales S. Synanthropic rodent reservoirs of Trypanosoma (Schizotrypanum) cruzi in the Valley of Caracas, Venezuela. Rev Inst Med Trop São Paulo 1997; 39: 279-82.

Higuchi ML, De Brito T, Reis MM, Barbosa A, Bellotti G, Pereira-Barreto AC, Pileggi F. Correlation between Trypanosoma cruzi parasitism and myocardial inflammatory infiltrate in human chronic chagasic myocarditis: Light microscopy and immunohistochemical findings Cardiovasc Pathol 1993; 2: 101-6.

Hoare CA. The trypanosomes of mammals. A zoological monograph. Oxford: Blackwell; 1972. p. 214.

Jaccard DB. Soc V Science Naturelle 1908; 44: 223-70. 
Junqueira $A C V$, Chiari $E$, Wincker $P$. Comparison of the polymerase chain reaction with two classical parasitological methods for the diagnosis of Chagas disease in endemic region of north-eastern Brazil. Trans $\mathbf{R}$ Soc Trop Med Hyg 1996; 90: 129-32.

Karsten V, Davis C, Kunn R. Trypanosoma cruzi in wild raccoons and opossums in North Carolina. J Parasitol 1992; 78: 547-9.

Kirchhoff LV. American trypanosomiasis (Chaga's diseases) a tropical disease now in the United State. N Engl J Med 1993; 329: 639-44.

Kirchhoff LV, Votava JR, Ochs DE, Moser DR. Comparison of PCR and microscopic methods for detecting Trypanosoma cruzi. J Clin Microbiol 1996; 34: 1171-5.

Luckow M, Pimentel D. Na empirical comparison of numerical Wagner computer programs. Cladistics 1985; 1: 47-66.

Magalhães JB; Andrade SG. Estudo do comportamento de cepas de Trypanosoma cruzi após passagem em diferentes espécies de triatomineos. Rev Soc Bras Med Trop 1991; 24: 209-16.

Mansfield JM. Non pathogenic trypanosomes of mammals. In: Kreier JP, editor. Parasitic Protozoa I. Taxonomy, kinetoplastids, and flagellates of fish. New York: Academic Press; 1977. p.297-327.

Marcondes CB, Guedes LA, Mendonça DD. Surto de doença de Chagas de provável contaminação oral, em Catolé do Rocha (Paraíba) - Encontro de Didelphis albiventris naturalmente infectado. In: $24^{\text {a }}$ Congresso da Sociedade Brasileira de Medicina Tropical;1988 Manaus, Amazonas. Resumo 29.

Marques de Araújo S; Chiari E. Caracterização biológica de clones das cepas $\mathrm{Y}, \mathrm{CL}$ e MR de Trypanosoma cruzi em camundongos $\mathrm{C} 3 \mathrm{H}$ isogênicos. Mem Inst Oswaldo Cruz, 1988; 83: 175-81.

Maslov DA, Lukes J, Jirku M, Simpson L. Phylogeny of trypanosomes as inferred from the small and large subunit rRNAs: implications for the evolution of parasitism in the trypanosomatid protozoa. Mol Biochem Parasitol 1996; 75: 197-205.

Mello DA, Valin E, Teixeira ML. Alguns aspectos do comportamento de cepas silvestres de Trypanosoma cruzi em camundongos e Calomys callosus (Rodentia). Rev Saúde Pública 1979; 13: 314-25.

Mello DA. Aspectos do ciclo silvestre do Trypanosoma cruzi em região de cerrado (município de Formosa, Estado de Goiás). Mem Inst Oswaldo Cruz 1981; 76: $227-46$. 
Mello DA. Roedores, marsupiais e triatomineos silvestres capturados no municipio de Mambaí-Goiás. Infecção natural pelo Trypanosoma cruzi. Rev Saúde Pública 1982; 16: 282-91.

Miles MA, Toye PJ, Oswald SC, Godfrey DG. The identification by isoenzyme patterns of two distinct strain-groups of Trypanosoma cruzi circulating independently in a rural area of Brazil. Trans $\mathbf{R}$ Soc Trop Med Hyg 1977; 71: 217-25.

Miles MA, Souza A, Póvoa M, Shaw JJ, Lainson R, Toye PJ. Isozymic heterogeneity of Trypanosoma cruzi in the first autochthonous patients with Chagas' disease in the Amazonian Brazil. Nature 1978; 22: 819-21.

Miles MA. Transmission cycles and the heterogeneity of Trypanosoma cruzi. In: Lumsden WHR, Evans DA, edtors, Biology of the Kinetoplastida. London: Academic Press; 1979 v 2, p. 117-96.

Miles MA, Lanham SM, Souza AA, Póvoa M. Further enzymic characters of Trypanosoma cruzi and their evaluation for strain identification. Trans $\mathbf{R}$ Soc Trop Med Hyg 1980; 74: 221-37.

Miles MA, Cedillos RA, Póvoa MM, De Souza AA, Prata A, Macedo V. Do radically dissimilar Trypanosoma cruzi strains (zymodemes) cause Venezuelan and Brazilian forms of Chagas' disease? Lancet 1981; 20: 1338-40.

Miles MA, Arias JE, Valente SAS, Naiff RD, Souza AA, Povoa MM, Lima JAN, Cedillos RA. Vertebrate hosts and vectors of Trypanosoma rangeli in the Amazon Basin of Brazil. Am J Trop Med Hyg 1983; 32: 1251-8.

Momen H. Taxonomy of Trypanosoma cruzi: a Commentary on Characterization and Nomenclature. Mem Inst Oswaldo Cruz 1999; 94 Supl 1: $181-4$.

Morel CM, Chiari E, Plessmann Camargo E, Mattei DM, Romanha AJ, Simpson L. Strains and clones of Trypanosoma cruzi can be characterized by pattern of restriction endonuclease products of kinetoplast DNA minicircles. Proc Nat Acad Sci 1980; 77: 6810-4.

Mott KE, Mota EA, Sherlock I, Hoff R, Muniz TM, Oliveira TS, Draper CC. Trypanosoma cruzi infection in dogs and cats and household seroreactivity to T. cruzi in a rural comunity in Northeast Brazil. Am J Trop Med Hyg 1978; 27:1123-7.

Noyes HA, Stevens JR, Teixeira MMG, Phelan J, Holz PA. A nested PCR for the ssrRNA gene detects Trypanosoma binneyi in the platypus and Trypanosoma sp. in wombats and kangaroos in Australia. Inte J Parasitol 1998; 29: 331-9. 
Nunes VLB, Oshiro ET. Trypanosoma (Trypanozoon) evansi in the coati from the Pantanal region of Mato Grosso do Sul State, Brazil. Trans R Soc Trop Med Hyg1990; 84: 692.

Nunes LR, Carvalho MRC, Buck GA. Trypanosoma cruzi strains partition into two groups based on the struture and function of the spliced leader RNA and rRNA gene promoters. Mol Biochem Parasitol 1997; 86: 211-24.

Oliveira EC, Stefani MMA, Luquetti AO, Vêncio EF, Moreira MAR, Souza C, Rezende. Trypanosoma cruzi and experimental Chagas'disease: Characterization of a stock isolated from a patient with associated digestive and cardiac form. Rev Soc Bras Med Trop 1993; 26: 25-33.

Oliveira Jr W. Prevalência da infecção chagásica e das formas da doença na região Nordeste. Rev Soc Bras Med Trop 1996; 29 Supl 2: 105-6.

Organisation Mondiale de la Santé. Lutte contre la maladie de Chagas: rapport d'un Comité OMS d'experts. Genève: OMS; 1991 (Série de Rapports Techniques, 811).

Osaki LS, Czeko YMT. Genomic DNA cloning and related techniques. In: Morel CM, editor. Genes and antigenes of parasites, a laboratory manual. Rio de Janeiro: Fundação Oswaldo Cruz; 1984. p.165-85.

Perlowagora-Szumlewicz A, Muller CA, Moreira CJC. Studies in search of suitable experimental insect model for xenodiagnosis of hosts with Chaga's diseases. 4 - The reflection of parasite stock in the responsineness of different vector species to chronic infection with different Trypanosoma cruzi stocks. Rev Saúde Pública 1990; 24: 165-77.

Pessóa SB. Hospedeiros vertebrados não humanos do Trypanosoma cruzi. Rev Goiana Med 1958; 4: 83-101.

Pietrokovsky SM, Schweigmann NJ, Riarte A, Alberti A, Conti O, Montoya S, Wisnivesky-Coli $C$. The skunk Conetatus chinga as new host of Trypanosoma cruzi in Argentina. J Parasitol 1991: 77: 643-5.

Prata A. Classificação da infecção chagásica no homem. Rev Soc Bras Med Trop 1990; 23: 109-13.

Ray DS. Conserved sequence blocks in kinetoplast minicircles from diverse species of trypanosomes. Mol Cell Biol 1989; 9: 1365-7.

Recinos FR, Kirchhoff LV, Donelson JE. Characterization of kinetoplast DNA minicircles in Trypanosoma rangeli. Mol Biochem Parasitol 1994; 63: 5967. 
Rêgo SFM, Magalhães AEA, Siqueira AF. Um novo trypanossomo do gambá, Trypanosoma freitase $n$. sp. Rev Bras Malariol Doenças Trop 1957; 9: 277-84.

Ribeiro RD, Barretto MP, Camargo CA, Takeda EKF. Estudo comparativo entre a eficiência de hemoculturas e xenodiagnósticos seriados efetuados em gambás do gênero Didelphis, naturalmente infectados pelo Trypanosoma cruzi. Rev Bras Biol 1984; 44: 389-94.

Ribeiro RD, Rissato Garcia TA, Bonoma WC. Contribuição para o estudo dos mecanismos de transmissão do agente etiológico da doença de Chagas. Rev Saúde Pública 1987; $21: 51-4$.

Rocha e Silva EO, Andrade LCR, Lima AR. Importáncia dos animais sinantrópicos no controle da endemia chagásica. Rev Saúde Pública 1975; 9: $371-81$.

Saiton $N$, Nei $M$. The neighbor-joining method: A new method for reconstructing phylogenetic trees. Mol Biol Evolution 1987; 4: 406-25.

Sartori AMC, Shikanai-Yasuda MA, Amato Neto V, Lopes MH. Follow-up of 18 patients with human immunodeficiency virus infection and chronic Chaga's disease, with reactivation of Chaga's disease causing cardiac disease in three patients. Clin Infect Dis 1998; 26: 177-9.

Schlemper Jr BR, Ishida MMI, Steindel M, Gargioni R. Tripomastigota muito largo como padrão morfológico de cepas do Trypanosoma cruzi do extremo Sul do Brasil? Mem Inst Oswaldo Cruz 1986; 81: 191-8.

Schmuniz GA. Trypanosoma cruzi, the etiologic agent of Chagas disease: status in the blood supply in endemic and nonendemic contries. Transfusion 1991; 31: 547-57.

Schofield CJ, Dias JCP. A cost-benefit analysis of Chagas diseases control. Mem Inst Oswaldo Cruz 1991; 86:285-95.

Schofield CJ, Dias JCP. The southern cone initiative against Chagas' disease. In: Baker JR, Muller $R$, Rollinson $D$, editors. Advances in Parasitology London: Academic Press; 1999. p. 2-22.

Schottelius J, Muller V. Interspecific differentiation of Trypanosoma cruzi, Trypanosoma conodhini and Trypanosoma rangeli by lectins and combination with complement lysis. Acta Trop 1984; 41: 29-38.

Schweigmann NJ, Pietrokovsky S, Bottazzi V, Conti O, Wisnivesky-Coli C. Interaction between Didelphis albiventris and Triatoma infestans in relation to Trypanosoma cruzi transmission. Mem Inst Oswaldo Cruz 1995; 90: 679-82. 
Shaw JJ, Lainson R, Fraiha $H$. Considerações sobre a epidemiologia dos primeiros casos autóctones de doença de Chagas registrados em Belém, Pará, Brasil. Rev Saúde Pública 1969; 3: 153-7.

Shikanai-Yasuda MA, Lopes MH, Tolezano JE, Umezawa E, Amato Neto V, Pereira Barreto $A C$, et al. Doença de Chagas aguda: Vias de transmissão, aspectos clínicos e resposta à terapéutica específica em casos diagnosticados em um centro urbano. Rev Inst Med Trop São Paulo 1990; 32: $16-27$.

Shikanai-Yasuda MA, Ochs DE, Tolezano JE, Kirchhoff LV. Use of the polymerase chain reaction for detecting Trypanosoma cruzi in triatomine vectors. Trans R Soc Trop Med Hyg 1996; 90: 649-51.

Silva EOR, Pattoli DBG, Camargo JC. Novo encontro do Trypanosoma (Megatrypanum) freitasi, parasita do gambá. Rev Saúde Pública 1976; 10 : $121-4$.

Silva LJ. Evolução da doença de Chagas no Estado de São Paulo. Ribeirão Preto; 1980. [Tese de Doutorado - Faculdade de Medicina de Riberão Preto /USP].

Silveira AC, Rezende DF. Epidemiologia e controle da transmissão vetorial da doença de Chagas no Brasil. Rev Soc Bras Med Trop 1994; 27 Supl 3: 11-22.

Simpson L. Kinetoplast DNA in trypanosomatid flagellates. Int Rev Cytol 1986; 99: 119-79.

Souto RP, Fernandes O, Macedo AM, Campbell DA, Zingales B. DNA markers define two major phylogenetic lineages of Trypanosoma cruzi. Mol Biochem Parasitol 1996; 83: 141-52.

Steindel M, Pinto CJC. Trypanosoma cruzi development in the anal glands of experimentally infected Lutreolina crassicaudata (Marsupialia, Didelphidae). Mem Inst Oswaldo Cruz 1988a; 83: 397.

Steindel M, Scholz A, Toma HK, Schlemper Jr BR. Presence of Trypanosoma cruzi in the anal glands of naturally infected opossum (Didelphis marsupialis) in the state of Santa Catarina, Brazil. Mem Inst Oswaldo Cruz 1988b; 83: 135-7.

Steindel M, Pinto CJC, Toma HK, Mangia RHR, Rodrigues RR, Romanha AJ. Trypanosoma rangeli (Tejera, 1920) in Santa Catarina Island, Santa Catarina State: First report of this trypanosome in southern Brazil. Mem Inst Oswaldo Cruz 1991; 86: 73-9. 
Steindel M, Dias Neto E, Menezes CLP, Romanha AJ, Simpson AJG. Random amplified polymorphic DNA analysis of Trypanosoma cruzi strains. Mol Biochem Parasitol 1993; 60: 71-80.

Sturm NR, Degrave W. Morel C, Simpson L. Sensitive detection and schizodeme classification of Trypanosoma cruzi cells by amplification of kinetoplast minicircle DNA sequences: use in diagnosis of Chagas' disease. Mol Biochem Parasitol 1989; 33: 205-14.

Sturm NR, Fernandes O, Campbell DA. The mini-exon of three Phytomonas isolates that differ in plant tissue tropism. Fed Euro Microbiol Soc Microbiol Lett 1995; 130: 177-82.

Tafuri WL. Patogênese. Rev Soc Bras Med Trop 1992; 25 Supl 3: 19-22.

Thomaz N, Deane MP. Continuous growth and differentiation of Trypanosoma (Megatrypanum) freitasi Rego, Magalhães \& Siqueira, 1957, in vitro. J Protozool 1990; 37: 40-43

Tibayrenc M, Neubauer K, Barnabé C, Guerrini F, Skarecky D, Ayala FJ. Genetic characterization of six parasitic protozoa: Parity between randomprimer DNA typing and multilocus enzyme eletrophoresis. Proc Natl Acad Sci USA 1993; 90: 1335-9.

Tolezano JE, Chieffi PP, Dias RMDS, Nunes EV, D'Ándrade OM, Pereira LE, et al. Trypanosoma do subgênero Herpetosoma Doflein, $1901 \mathrm{em}$ Proechimys iheringi Thomas, 1911 capturados no Estado de São Paulo, Brasil. Rev Inst Adolfo Lutz 1984; 44: 47-53.

Tolezano JE, Araujo MFL, Balanco IMF, Valentin AM, Barca ML. Leishmania sp isolated from blood heart of Akodon sp (Rodentia, Cricetidae) caught in Iguape City, São Paulo State, Brazil. Proceedings of $15^{\text {th }}$ Annual Meeting on Basic Research in Chagas'diseases; 1988. Caxambu, Minas Gerais, Brazil.

Tolezano JE, Taniguchi HH, Bisugo MC, Araujo MFL, Cunha EA, Elias CR, Larosa R. Occurence of natural Leishmania(Leishmania) infection in Proechimys iheringi in an endemic area of human na canine American Cutaneous Leishmaniasis due to Leishmania (Viannia) braziliensis in Ilha bela, São Paulo, Brazil. Rev Soc Bras Med Trop 1999; 32 Supl 1: 254-5.

Valente SAS, Valente VC. Reservatórios e vetores do Trypanosoma cruzi e a vigilância epidemiológica da doença de Chagas na Amazônia brasileira. NewsLab 1996; 16: 33-5.

Valente SAS, Valente VC Fraiha Neto $H$. Considerações sobre a epidemiologia e transmissão da doença de Chagas na Amazônia brasileira. Rev Soc Bras Med Trop 1999; 32 Supl 2: 51-5. 
Vallejo GA, Macedo AM, Chiari E, Pena SDJ. Kinetoplast DNA from Trypanosoma rangeli contains two distinct classes of minicircles with different size and molecular organization. Mol Biochem Parasitol 1994; 67: 245-53.

Wanderley DMV. Vigilância entomológica da doença de Chagas no Estado de São Paulo. Rev Saúde Pública 1991; 25: 28-32

Wanderley DMV. Planejamento, problemas e resultados da vigilância epidemiológica da doença de Chagas no Estado de São Paulo. Rev Soc Bras Med Trop 1994a; 27 Supl 2: 68-70.

Wanderley DMV. Perspectivas de controle da doença de Chagas no Estado de São Paulo. São Paulo; 1994b. [Tese de Doutorado - Faculdade de Saúde Pública/USP].

Wisnivesky-Colli C, Gurtler RE, Solarz ND, Lauricella MA, Segura EL. Epidemiologycal role of humans, dogs and cats in the transmission of Trypanosoma cruzi in a central area of Argentina. Rev Inst Med Trop São Paulo 1985; 27:346-52.

Wisnivesky-Coli C, Schweigmann NJ, Alberti A, Pietrokovsky SM, Conti O, Montoya S, Riarte A, Rivas C. Sylvatic American trypanosomiasis in Argentina. Trypanosoma cruzi infection in mammals from the Chaco forest in Santiago del Estero. Trans R Soc Trop Hyg 1992; 86: 38-41.

Yoshida ELA, Silva RL, Cortez LS, Corrêa FMA. Encontro de espécies do gênero Leishmania em Didelphis marsupialis aurita no Estado de São paulo, Brasil. Rev Inst Med Trop São Paulo 1979; 21:110-3.

Yoshida N. Surface antigens of metacyclic trypomastigotes of Trypanosoma cruzi. Infect Immun 1983; 40: 836-9.

Zavala-Velázquez J, Barrera-Pérez M, Rodriguez-Félix ME, Guzmán-Marín E, Ruiz-Piña H. Infection by Trypanosoma cruzi in mammals in Yucatan, Mexico: A serological and parasitological study. Rev Inst Med Trop São Paulo 1996; 38: 289-92.

Zingales B, Pereira ME, Almeida KA, Umezawa ES, Nehme NS, Oliveira RP, et al. Biological parameters and molecular markers of clone CL Brener. The reference organism of the Trypanosoma cruzi Genome Project. Mem Inst Oswaldo Cruz 1997; 92: 811-4.

Zingales B, Souto RP, Mangia RH, Lisboa CV, Campbell DA, Coura JR, et al. Molecular epidemiology of American trypanosomiasis in Brazil based on dimorphisms of rRNA and mini-exon gene sequences. Int J Parasitol 1998; 28: $105-12$. 


\section{ANEXOS}

1. Meios de cultura:

\subsection{Caldo BHI (Instituto Adolfo Lutz):}

Composição do meio básico (Difco):

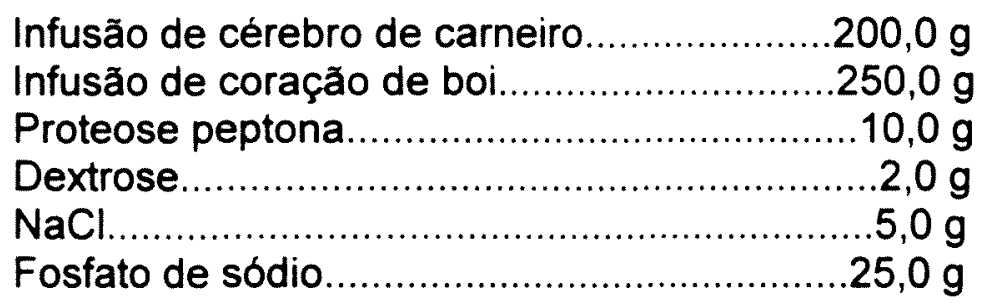

Dissolver $37 \mathrm{~g}$ do meio básico em $1000 \mathrm{ml}$ de água destilada. Acertar para $\mathrm{pH} 7,4$. Distribuir $2,0 \mathrm{ml}$ do meio em tubos estéreis de rosca (12X120 mm). Autoclavar a $121^{\circ} \mathrm{C}, 15$ minutos. Deixar em temperatura de $28^{\circ} \mathrm{C}$ por 48 horas para teste de esterilização. Conservar em geladeira.

\subsection{Ducrey - Segundo Salles Gomes (Instituto Adolfo Lutz):}

Agar infusão de batata (Difco).....................14,7g

Glicerina P.A (Merck)...............................2,0 ml

Agua destilada q.s.p...........................210,0 ml

Dissolver o agar em água quente e adicionar a glicerina. Autoclavar a 121 ${ }^{\circ} \mathrm{C}, 15$ minutos. Resfriar a base a $50{ }^{\circ} \mathrm{C}$ e adicionar $90 \mathrm{ml}$ de sangue desfibrinado de coelho a $30 \%$. Homogeneizar. Distribuir $5,0 \mathrm{ml}$ do meio em tubos estéreis de rosca $(16 \times 160 \mathrm{~mm})$. Inclinar os tubos e deixar em repouso por 24 horas. Conservar em geladeira.

\subsection{LIT (Departamento de Parasitologia ICB-USP):}

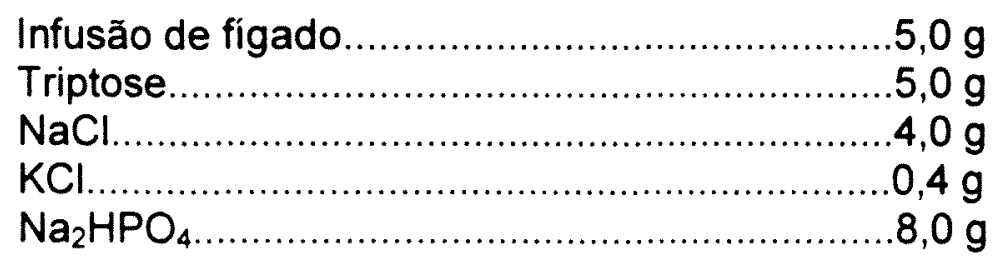

Dissolver os compomentes em água. Adicionar Hemina $(10 \mathrm{mg} / \mathrm{ml})$. Acertar para $\mathrm{pH} 7,2 \mathrm{com} \mathrm{HCl} 0,3 \mathrm{M}$. Completar o volume com água para $850 \mathrm{ml}$. Autoclavar a $121^{\circ} \mathrm{C}, 30$ minutos. A parte dissolver $2,0 \mathrm{~g}$ de glicose em 50,0 $\mathrm{ml}$ de água. Autoclavar $121^{\circ} \mathrm{C}, 15$ minutos. Juntar esterilmente, $850,0 \mathrm{ml}$ do meio, $50,0 \mathrm{ml}$ de glicose e $100,0 \mathrm{ml}$ de soro fetal bovino inativado a $56{ }^{\circ} \mathrm{C}$ 
por 1 hora. Aliquotar em volume de $250,0 \mathrm{ml}$. Deixar a $28^{\circ} \mathrm{C}$ por 48 horas para teste de esterilização. Conservar em geladeira.

\section{Soluções:}

\subsection{PBS (pH 7,2):}

$\mathrm{Na}_{2} \mathrm{HPO}_{4} 4 \mathrm{mM}$

$\mathrm{KH}_{2} \mathrm{PO}_{4} 4 \mathrm{mM}$

$\mathrm{NaCl} 140 \mathrm{mM}$

$\mathrm{KCl} 2 \mathrm{mM}$

\subsection{Tampão Tris Salino-EDTA (SE):}

$\mathrm{NaCl} 0,15 \mathrm{M}$ $100,0 \mathrm{ml}$

EDTA $2,5 \mathrm{mM}(\mathrm{pH} 8,0)$ $1,0 \mathrm{ml}$

Tris $2,5 \mathrm{mM}(\mathrm{pH} 8,0)$. $100,0 \mathrm{ml}$

\section{Solução 1. $\mathrm{NaCl} 0,15 \mathrm{M}$}

Adicionar $1,75 \mathrm{~g}$ de $\mathrm{NaCl}$ em $200 \mathrm{ml}$ de água destilada. Autoclavar $120^{\circ} \mathrm{C}$, 30 minutos.

Soluçăo 2. EDTA $2,5 \mathrm{mM}(\mathrm{pH} 8,0)$

Adicionar $9,3 \mathrm{~g}$ em $50,0 \mathrm{ml}$ de água destilada. Ajustar $(\mathrm{pH} 8,0) \mathrm{com} \mathrm{NaOH}$ em pastilhas. Autoclavar $120^{\circ} \mathrm{C}, 30$ minutos.

Solução 3. Tris $2,5 \mathrm{mM}(\mathrm{pH} 8,0)$

Adicionar $0,06 \mathrm{~g} \mathrm{em} 200,0 \mathrm{ml}$ de água destilada. Autoclavar $120^{\circ} \mathrm{C}, 30$ minutos.

\subsection{Tampão Tris Cloridrico-EDTA (TE):}

$10 \mathrm{mM}$ Tris- $\mathrm{HCl}(\mathrm{pH} \mathrm{7,4)}$

1 mM EDTA (pH 8,0)

\subsection{Tampão da reação de PCR:}

$200 \mathrm{mM}$ Tris- $\mathrm{HCl}(\mathrm{pH} \mathrm{8,4)}$

$500 \mathrm{mM} \mathrm{KCl}$

$1,5 \mathrm{mM} \mathrm{MgCl}_{2}$ 